Berry, Edward Wilber

The flora of the Cheyenne

sandstone of Kansas 


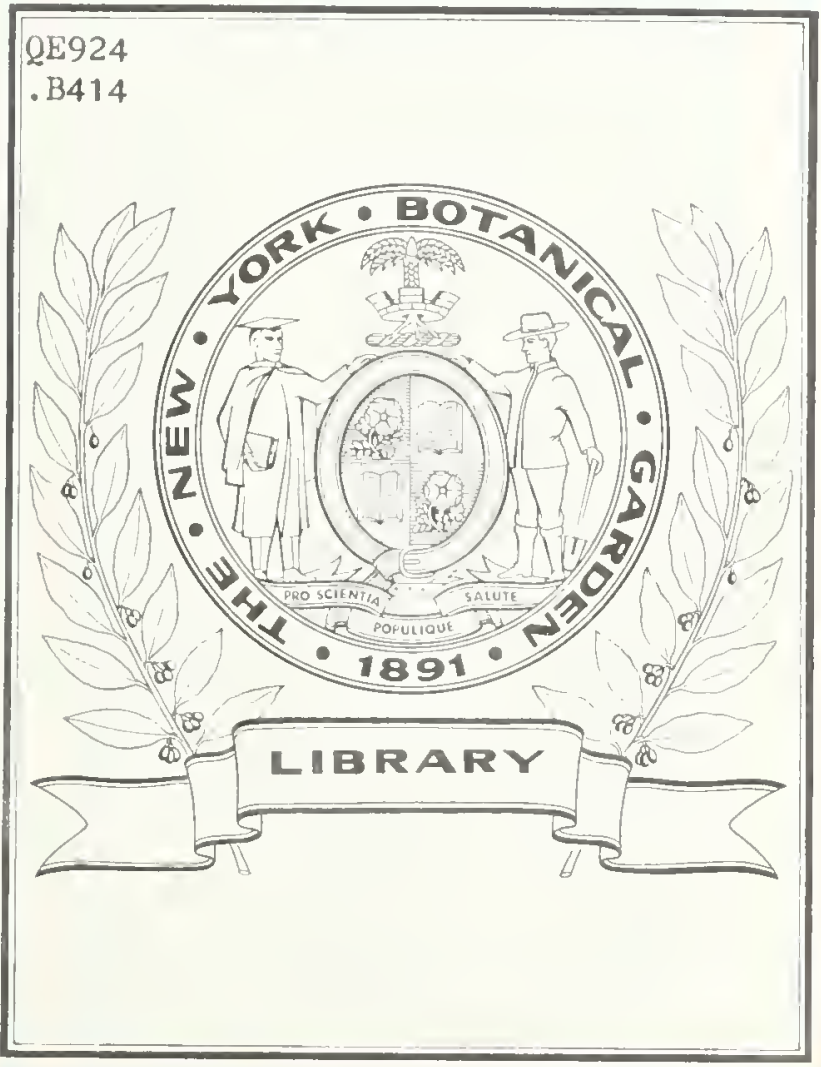






\section{DEPARTMENT OF THE INTERIOR}

Albert B. Fall, Secretary

UNITED STATES GEOLOGICAL SURVEY Gforge Otis SMith, Director

Professional Paper 129-1

\section{THE FLORA OF THE CHEYENYE SANDSTONE OF KANSAS}

EDWARD IVILBER BERRY

Published April 11, 1922

Shorter contributions to general geology, 1921

(Pages 199-225:

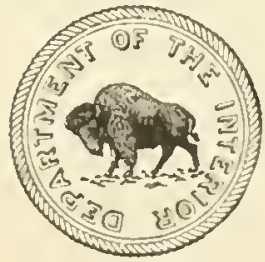

WASHINGTON

GOVERNAENT PRINTING OFFICE 1922 


\section{CONTENTS.}

Page.

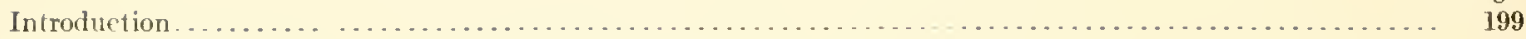

Historical summary . . . . . . . . . . . . . . . . . . . . . . . . . . . . . . . . . . . . . . . . 199

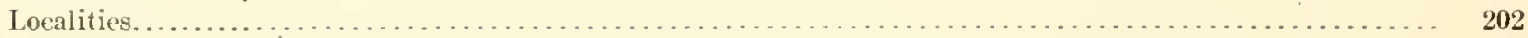

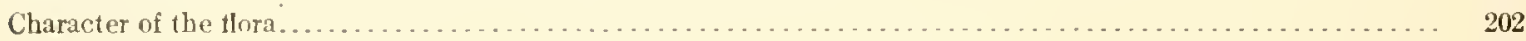

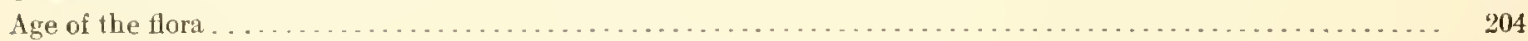

Systematic deseriptions . . . . . . . . . . . . . . . . . . . . . . . . . . . . . . . . .

\section{ILLUSTRATIONS.}

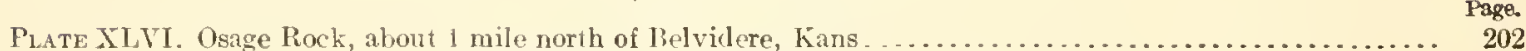

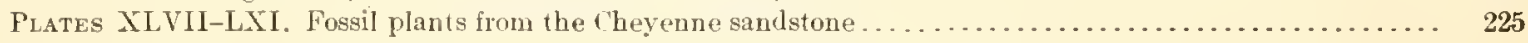

NOTE.-The papers included in the annual volume "Shorter contributions to general geology" are issued separately, with the final pagination, as soon as they are ready. The last paper will include a volume title-page, table of contents, and index for the use of those who may wish to bind the separate parts. A small edition of the bound volume will also be issued, bnt copies can not be supplied to those who have received all the parts. 


\title{
THE FLOKA OF THE CHEYENNE SANDSTONE OF KANSAS.
}

\author{
By Enwarn Whase Brarto.
}

\section{INTRODUCTION.}

The present study is based on collections made by Hill in 1894, Ward and Vaughan in 1596, Ward, Gould, White, and Cain in 1597, and Lee in 1919. These collections were very extensive, but the lualk replesented small framents of the more abundant species, such as the Sequnia and Sapindopsis. The florn itself as at present known consists of a rery small number of speries.

The Cheyenne sandstone comprises ahout 100 feet of gray to yellow friable quartz sandstone with subordinate lenses of dark shalc. The sardstone ranges from fine to coarse and contains a few layers of quartz and chert pelbbles. It is in the main only slightly consolidated and is very friable and casily eroded. The bedding is extremely irregular' and discontinuous, and cross-hedding is obvious throughout and in places extremely pronouneed. Logs of silicified wood and Cycadeoidea minuta from these beds were recorded by Cragin."

The Cheyenne sandstone rests upon "Red Beds" of supposed Permian age and is orerlain by the Kiowa shale-shallow-water and lagoon deposits of alternating layers of marl and bituminous clay shale, with a marine fauna that includes many species characteristic of the Washita group of the Texas Cretnceous.

The invertebrates are said by Twenhofel to number about 50 species, of which the following are some of the commoner forms:

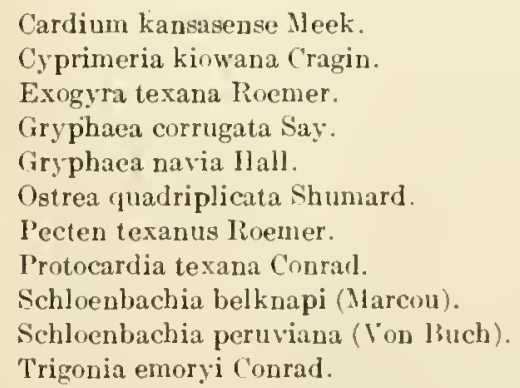

1 C'ragin, F. W., Washburn Coll. Lab. Nat. Hist. Hull, vol. 2, pp. $65-66,1859$.
In some places the Tortingy overlies the Kiowa; elsewhere the following inits in ascending order have been recognized by Gould: Spring Creek chays, Greenleaf sandstone, Kirby clays, and Reeder sundstone. The numes are those proposed by Gould and Cragin and have not been formally recognized by the Inited States Geological Survey. These units are chiefly local phases or lentils in the Kiown, of little significance except as indicative of local und more or less contemporaneous variations in conditions of deposition, with perhups a basal member of the Dakota sandstone represented in the "Reeder."

\section{HISTORICAL SUMMARY.}

The term "Dakota group" was first usod in 1861 by Neek and Hayden ${ }^{2}$ for" the lower portion of their section of the Cretaceous of Nebraska, corresponding to No. I of the chussic Meek and Hayden Upper Missouri section. ${ }^{3}$ This term or simply Dikota or Dakota sandstone has subsequently been used in imnumerable references to loeal geologic sections throughout the Wrest. The assumption that the Upper Cretaceous of that whole region contained two persistent sandstones-the $\mathrm{D}_{\mathrm{iL}}$ kota at its bottom and the Fox llills near its top-and the fancied reconnition of these sandstones over a wide area have caused much of the confusion and controversy that have arisen over the interpretation of the western Cretuceous.

As originally understood the term Dakota was applied to the pre-Benton Cretaceous, no Lower Cretaceous being then recognized in that region. Unquestionably the typieal Dakota sandstone represents the littoral or marginal deposits of the trunsgressing Benton sen, but that there are similar and somowlat earlier continental or marginal sandstones in

2 Jeek, F. B., and IIayden, V. V., Acal. Nat. Sci. I'bilathlphis Froc., vol. 13, 13. 419, $1.56 \mathrm{l}$.

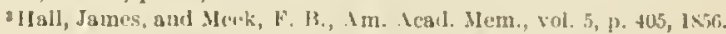
Mock, F. [3., aud dLayden, F. Y., Acad Nat. Sei. I'hiladulphia l'roc., vol. s, p. $63,1556$. 
liansals, Colorado, the westeru Black Hills, and presmmally alsewhere in this region has been protty well known for a number of years. Therie ract anc has been a matter of eonsideralile differences ol opiniou.

The history of palcobotanie discovery of the so-called Daliota flora las been griven in Lespuereux's three memoirs and need not bo recounted here cxrept to point out that the collertions, a study of which resulted in the identification of over 400 speries of plants, were made at diflerent times and places by a number of different collectors, who, as in so much of the early exploratory work in the West, pail little attention to stratigraphic position or locality. Iny yellowish or reddish sandstone with inpressions of dicotyledonous leaves was Dakota in age, and for a large number of species "Ditkota group of Kansas," or at most the county from which the specinens wero collected, is all we know of the whereabouts of the outerop.

Apparently the lirst to notice marine fossils at the base of the red Cretaceous (Dakota) sandstones was lae Conte." Cragin, while at Washburn College, Topeka, Kinss., did much work upon the Cretaceous and published many short paleontologic papers. In 1590 he described a cross-bedded sandstone (the Cheyenne sandstone) which underlay marine beds in southern Kansas and which he considered to be related to the Potomac, Tuscaloosa, Trinity, and "Athandosumrus beds," and the next rear he published the statement that the Cheyenne sandstone was probably of the same age as the Trinity of 'Texas, the Potomac of the Ithutic Coastal Plain, and the Wealden or Purbeck of Europe. Invariably in his discussions he used the term Comanche as the interchangeable equivalent of the Europenn Neoromian.

The first definite announcement of the flor'a contrined in the Cheyenne sandstone was made by Hill, ${ }^{5}$ who recorded the following species from collections made hy Hill, Gould, and Shatfuck in 1s94:

Rhus uddeni lestyuereux.

Sterculia snowii Lesquereux.

Sassafras mudgii l.esruereux.

- Le Conte, J. L., Notes on the geolagy of the survey for the extension of the Uniou Pacific Radway, Philadelplia, 1N65.

5 Ifill, R. T., Discovery of a dicotyledonous flora in the Chey'nne sandstone: Am. Jour. Sei., 3d ser., vol. 49, p. 473, 1595; ")n outlyiug areas of the Comancheseries iu Kansas, Oklahona, and New Mfexieo: I/lem, vol. 50 , pp. $205-234,1595$.
Sassafras cretacoum obtusum Lesquereux.

Sassifras 11. sp.

rilyptustruhus gracillimus Lesupuereux.

Serpuoia sp. (chnes).

Cragin's conclusions were given in a paper publisher in $189.5,{ }^{\circ} \mathrm{in}$ which the section is giren as follows:

Kiowa shales.

"hampion shell led. $\left\{\begin{array}{l}\text { Elk creek heds }\left\{\begin{array}{l}\text { Stokes sandstone } \\ \text { Lanphier shale. }\end{array}\right. \\ \text { Corral sandstone. }\end{array}\right.$

From the "Elk Creek heds" he recorded Strentia snowiz, Sassafras mudypi, Sassafras cretacenm, Sassafras sp., Rhus uddeni, Sequoia sp., and Glyptostrobus gracillimus. ${ }^{7}$ Only the first two of these are contained in the collections studied by me.

Other contributors to the subject prior to 1900 were Mulge, Prosser, .Jones, Stanton, und Gould. Their results are not pertinent to my present purpose beyond the fact that they show conclusirely the presence of a sandstone, the Cheyenne, containing the remains of a land flora in southern Kiansas beneath a marine series, the liowa shale, carrying a fuma that is correlated with that of the Washita group at the top of the supposed Lower Cretaceous section of Texas as elaborated by Hill.

During his residence in Kansas Twenhofel studied the Cretaceous of the central part of the State, and in a brief paper ${ }^{8}$ published in 1917 he confirmed Cragin's earlier results ${ }^{\circ}$ that a situation identical with that of southern Kansas prevails in central Kansas. In a more recent article ${ }^{10}$ he contends that the Dakota of Finsas and the Washita group of Texas are of the same age, and that both the CheyenneKiowa-"Medicine beds" sequence of southern Fiansas and the Mentor-Dakota sequence of central Kansas should be referred to the Comanche series.

The "Dilkota flora" of the Denver Basin has recently been revised by linowlton. As a result of ficld work by Lee and Cannon during 1916 it has been shown ${ }^{11}$ that the formation from which Lieut. Beckwith collected the "Dakota" plants from Morrison, Colo., that

G Cragin, F. W., A study of the Belvidere beds: Am, fieologist, vol. 16, pp. $35 \%-385,1,495$.

7 Idem, P. $36 \%$, quoted from IIill.

8 Twenhofel, W. H., Kansas Aead. Sei. Trans., vol. 28, pp. 213-223, 1917. 9 Cragin, F. WV., Am. Coologist, vol. I6, pp. 162-165, J\$4.

10 Twenholcl, W. II., Am. Jour. Sci., 4 th ser., vol. 49, pp. 281-297, 1920. 11 Lee, W. T., Am. Jour. Sei., 4th ser., vol. 49, pp. 183-189, 1920 
Lespuereux aleseribed is the same as that described by licharelsun ${ }^{12}$ in 1915 as the Purcatoire formation and referred to the top of the Lower Cretaceous. This formation has also frequently been called "Lower Dakota." Below this, in the trpe section at Morrison and within the Morrison formation ("Allantosaurus beds") as originally (leseribed, there is about 100 fect of friable sandstone amd shale containing traces of a flom similar to that found in the orolying sandstone. This flora has been discusserl by Knowlton, ${ }^{13}$ who quite rightly concludes that it is I pper Cretaceous.

I am not roncerned in this papel with the taxonomie proposuls regarding what shall be the stratigraphic limits of the Dakota, but solely with the general relations and their benring on the geologic history of the fourion and the boundary between Lowes and Upper Cretureous.

It has been customary for geologists, particularly those who had a leaning toward philosophy, to postulate a rhythm of positire and negative morements of the strand by which the boumdaries of the different systems could readily be determined. Thare may be some pluysical basis for this enception, but it should be recalled that all series of changes can be considered rhythmic, with some elasticity in the application of critelia, and I am one of those reactionaries who believe that, however imperfect the scheme as derisel for the region first and longest studied, namely, Furope, the classic names and approximate limits of the systems should be adhered to; for, after all, the best classifications, whether of geologic time or of formations, igneous rocks, or organisms, are those which are most easily understood and useel.

Time is continuous, time bounlaries are always subjective, and the time-honored terms Permian or Triassic or "Lower Carboniferous" or Lower Cretareous are to me as essential to chear thinking and the interehange of geologic ideas among nations as the minutes, hours, and days of the current time scheme. however illogical these may seem in sidereal astronomy.

According to the enstomary American scheme the Lower Cretaceous should be con-

12 Richardson, G. 13., [†. S. Geol. Survey (icol. Atlas, ('astle Rock folio (No. 195), 1915.

IJ Konowlton, F. II., Am. Jour. Sci., 4th ser., vol. 49, 1). 1\$9-191, 1920. siclered to have ended with the withdrawal of the lower Cretacereus sea and the Ippere Cretacens to have begun with the initial trunsuression of the Lpper Cretuceous seat There the interval between these two events was lome, with continental deposition, mudel confusion and difference of interpretation results. 1 rassic instance of such diflerences is the rontroversy over the boundary between the Cretaceous and Tortingy in the fireat plains and Rocky Mountain region of Sorth Ameriea, which the 'lertiary sea was so ineonsiderate as not to invale. If geology at its inception hat concerned itsolf chicfly with continental deposits and land plants and animals and had ignored marine formations and life the situation would be exactly reversed, and the marine sodiments would probably be those in dispute.

On none of the continents, so far as I can discorer, did the sea complete a crele of invasion and witheliawal of what might be called the first magnitude during the Lower Cretaccous epoch. In the Atlantic Coastal Plain no marine Lpper Cretaceous deposits earlicr than the European Turonian are known ex(ept in the Texas area, where marine formations representing a part lut not all of the Lower Cretaceous of Europe arlyanee laaltingly from the south. The olelest of these formations is the Trinity, which in my julgment is nowhere as old as the Neocomian of Europe. This is followed by the fircelericksburg group, which Hill called Nteocominn but which contains a younger fauma. If one disregards Böse's correlations of the Mexican Cretaceous on the ground that Mexico is too remote from the north lexas-Kansas area, Whitney's studies of the faum of the Buda limestone not only elearly show its Cenomanian age but also show that it is late Conomanian. Similarly the fauna of the Georgetown limestone is Cenomanian. (Whitney has refrained thus far from making any intercontimental (oorclations.) $1 t$ is a striking confirmation of this correlation that the Buda limestone near Austin and hence in the region of more continuous marine conclitions than farther north should he immediately overlan ly the Turenian Eagle Ford formation. The problem of working out the interfingering of formntions between north and central Texus is largely a problem of invertabinte palconteblogy 
and woulal not be mentioned in the present romusetion if it were not for the necessity of showing that the rorrelation of the Texas Conanche series witl the Lower Cretaceous of timope is incorrect and "an not hope to be ultimately arecpted, and beeause this problem is so intimately bound up with the age of the Clicyenne sandstone.

If there is no marine Lower Cretaceous in Kansas, as I contend, our ideas of the sequence of erents from late Lower Cretaceous time into the ('pper Cretaceous require to be very greatly modified.

With regrid to 'Jwenhofel's proposal to refer the Mentor and Dakota of central Kansas to the Comanche, all that I can say is that while he and before him Cracin and others have written about the Dakota flora, this term is altogether meaningless stratigraphically, except that it denotes in a most general way a change in facies hetween Lower and Lpper Cretaceons floras. The llora of the Cheyenne sandstone, and I presume that in the Mentor formation as well, is no more like that of the Woodhine sand than the Woodbine flora is like that of the sereral formations of the Nontana group, and the reference of the Dakota sandstone-that is, the post-Mentor Dakota sandstome of central Kansas-to the Lower Cretaceous if correct would of necessity carry with it the Bingen sand of Arkansas, the Tuscaloosa formation of Alabama, the Black Creek formation of the Carolinus, and the Magothy formation of New .Jersey and Maryland, against whose correlation with the Senonian of Europe by paleozoologists I have been arouing for years, with not rery great success.

\section{LOCALITIES.}

All the localities from which fossil plants were collected in the Cheyenne sandstone are in the immediate vicinity of Belvidere, Kiowa County, Kans. (See Pl. XLVI.) I give below a transcription of the locality numbers, with the names of the collectors and dates, taken from the United States Geological Surrey's records. There appears to be some confusion in the two collections numbered 2224, nor do I have locality numbers for the material collected by Ward and Vaughan in 1896 . These defects in the record are immaterial, howerer, for there is no doubt that all the material studied came from the Cheyenne sand- stone in this immediate region. Many of the numbers are duplications of identical outerops and are given only as a matter of record.

773. Black hills near Relvidere; colleeted lit IIill, ronld, and Shat tuck, 1894.

2217. (Isage liock at Bel videre, from Nos, 1 and 2 of IIill's section; collected by (). 1. Cain, 1897.

2215. (Ine and one-half miles northwest of Belvidere, from No. 3 of Hill's section; collected ly. IIard and Frould, 1597

2219. Same as 773. Stokes 1Iill. 100 yards soutl of the Sational Corral; collected by Ward and Could, 1597.

2220. Stokes Hill, the most northeasterly of Hill's localities; collected by rould, 1897.

22.21. Thompson Creek near the flume, 2 miles northwest of Belvidere; collected by Ward and rould, 1897.

2202. ('hampion (Wildeat) lraw, three-fourths mile soutl of Belvidere; collested by Mard, Could, and White, 1897

2223. Same locality and rollertors as 2222. from the 'Lanphier shales."

2224. Near Nedicine Lodge River, 2 miles mest of Belvidere (original loeality of Ward and Vaughan in 1896); collected by Ward and finuld.

2224. ('hampion (Wildcat) I)raw, richt (east) branch, in "Ianphier shales," half a mile south of Belvirlore; collerted by Ward and Fould, 1897.

2225. One mile southwest of liel videre, in a draw (" Lanphier shales"); collerted by Ward and frould, $189 \%$.

2226. Abont $2 \frac{1}{2}$ miles due west of Belvidere (fern bed of 1896); collecterl by Ward and Gould, 1597 .

2227. Hills between Spring (reek and Soldier, 4 miles northeast of Belvidere; collected by Mard and Gould, 1897. 2025. ('hampion (Wilckeat) Iraw, right (rast) branch, "Lamphier sluales," half a mile south of Belvidere; rollected by 11 ard and Could, 1897.

2299. Left bank of middle branch of ('hampion (Wildcat) Draw, half a mile south of Belvidere; collected by Ward and Gould, 1897.

2230. Draws north of Jielvidere ("Lanphier shales"); collected by Hard and Gould, 1897.

2231. Right bank of midclle branch of ('hampion (Wildeat) Draw, half a mile south of Belvidere; collected by IVard and Gould, IS97.

2232. Osage Rock at Pielvidere, "Stokes sandstone" below the so-called ('hampion shell bed; rollected by Ward and Gould, 1897.

2233. First ciraw west of ('hampion (Wildeat) lbar, half a mile south of Belvidere; collected by Ward and Gould, 1597 .

7405. Wildcat [1raw, near Belvidere; collerted by II. T. Lee, 1919.

7406. (bsage Rork, near Belvilere; collected by W. T. Lee, 1919

\section{CHARACTER OF THE FLORA.}

The flori of the Cheyenne sandstone as disclosed in the present study numbers but 23 species. It comprises four ferns representing the families Polypodiacene and Gleicheniacear, and all four are representatives of widely 


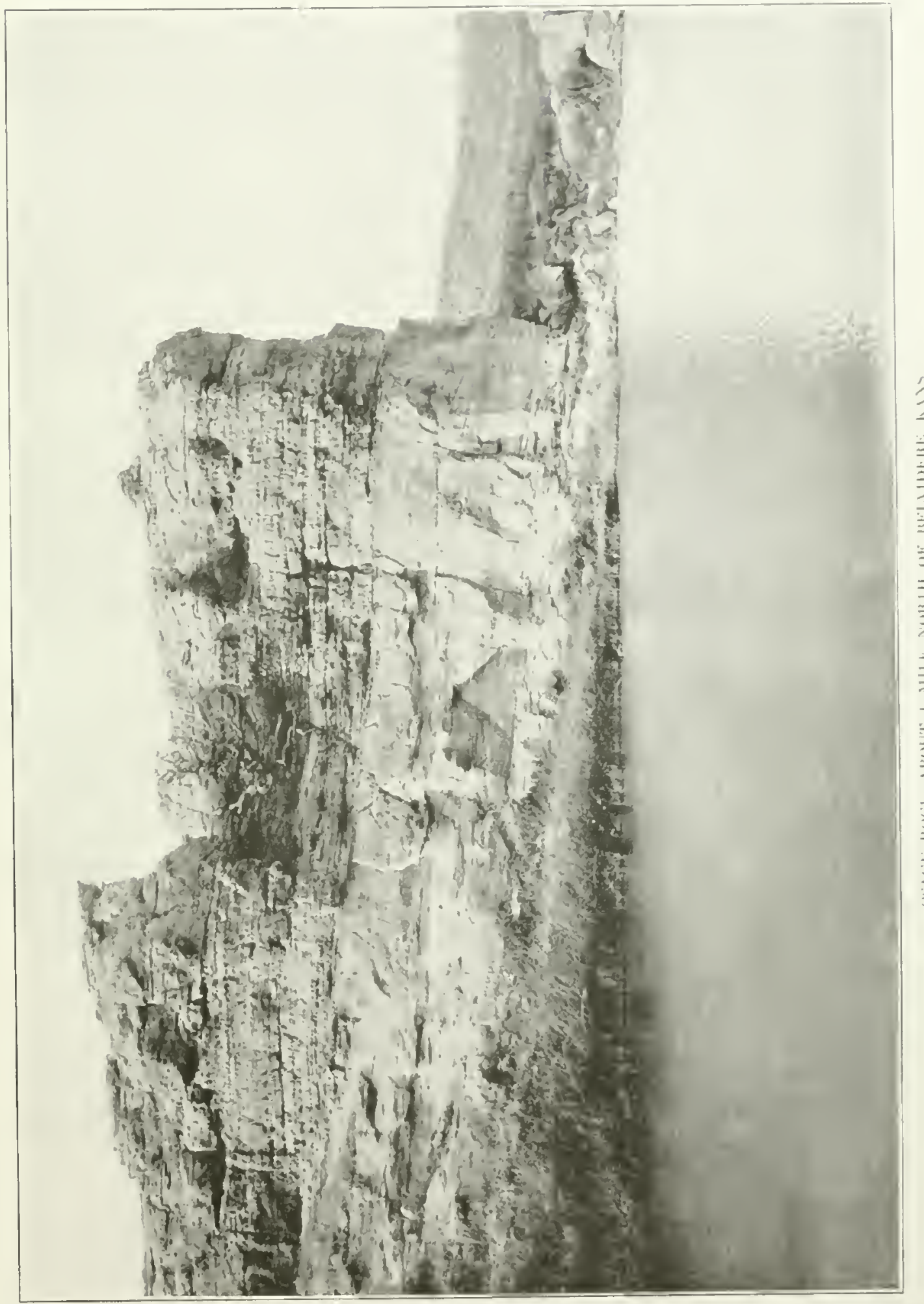



ranging and more or less well known Crotuceous types. The collections include a supposed cradophyte seed, but this is of clombtful relationship. There is also a frugment of a trunk of the genus rycadonider, which is of somewhat uncertain value, us its exact stratigraphic position has been guestioned. There are four coniferopluytes and cleven meriosperms. One of these is a supposed monocotyledon, ten are dicotyledons, and there are two forms of uncertain botanic relationships.

The dieotyledons represent the orders Sapindales, Malrales, Thymeleales, and Umbellales and are remarkable for the total absence of a large number of elements generally found in floras of this age. This alsence can not be wholly explained by accidents of preservation and discovery and is due, I believe, to the peculiar ecologic grouping resulting from the environment.

The arenaceous portions of the Cheyenne sandstone are rery conspirmously cross-beddod. The material is very friable, and the regetable remains are embedded in all sorts of positions and curled as they are when covered in a dry condition by wind-blown sands. All are coriaceous forms, and the abundant Sequaia eones all have their scales shrunken and widely distended as in thoroughly desicuted modern cones. They appear to have blown about and collected in hollows along with the coriaceous leaves that are found in association with them. With a single exception the ferns are found in the elays and evidently were eonfined largely to stream banks.

The variety of plants in such situations may have been larger than the discovered flora indicates, but it would seem as if in collections so extensire there shoukl be some traces of the other plants preserved if they were growing near at hand.

Although the flora is 100 small and too remote in time from existing floras to afford satisfactory ecologic data, it does furnish some suggestions. It seems to me to indicate a warm and more or less arid elimate, with a sparse vegetation. I picture this regetation as of meager variety and as huving been contined largely to the region of waterourses between which were larger areas of sand-hill or bealdhdune country over which the dried leaves and fruits were blown, collecting in the hollows and beconing covered by wind-blown sands. The "lay lemses for exumple. Cragin's "Lamphier beds"-are waterlaid and might represent scasonal ruinfall and lloul-plain or playa deposits or normal stream sedimentation, and it is possible that some of the sunds had a like origin.

There is no evidence of uridity in iny of the Cretaceous floras with which the Clieyenne sandstome flora may be compared. whether such comparisons are malc with the Jatapsea and Fuson floras, on the one hame, or the Woodlune, Dakota, and 'Huscaloos lloras, on the other. I believe, therefore, that the Cheyenne flora does not represent general comditions but is purcly an expression of the local en rironment and perhaps represents a wide sandy coustal plain or fluctuating beaches backed by dunes, and that farther inland a more varied and normal flora probably existed throughout the period when the shallow sea was migrating back and forth across southern limnsas.

A sample of the Cheyenne sundstone wis submitted to Mr. Mareus I. Goldman, who has kindly furnished the appended obsorvations:

Iacroscopir eramination.-A solid lut friable tinegrained sandstone of a pale lavender-brown color chararteristic of moderately carbonaceous sandstones. Io lamination. Contains eurled and wrinkled leat impres. sions suggestive of deposition in a dry condition, hener in wind-blown sand.

Mechaniral analysis. - The rock could loe easily rublerl down into its constituent grains. On sieving these divided as follows: Fine sand through 60 on 100 mesh, 12.9 per (ent, $0.45-0.26$ millimeter; very fine sand through 100 on 200 mesh, 82.2 per rent, 0.26 0.0.I millimeter; extra line sand through 200 mesh, 4.9 per rent. less than 0.04 millimelur. Hieroscopic examination showed that the wo finer parts contained thoroughly disinteurated grains. The coarsest, however, consisted largely of rompound grains which vielded slowly to disintegration, so the following roush figures may be taken: Fine sand, 5 per rent; very tine sand, 90 per cent; extra fine sand, 5 per cent. In either ("ase the great predominance of the very tine sand is obvions. This predominane of a single size at once suggests wind artion, but comparison with dune sands (of. my paper on the ('atahoula sandstone, ${ }^{14}$ where several analyses art assembled) shows that the maximum is in the size next finest to that which forms the maximum in typical dune material. I have looked up the large (ollertion of analyses giv'n by Idden ${ }^{15}$ and lind that in this elaracter the sample rosembles the finer sund carried ly the wind out of other deposits. Thus it corresponds will only two of his June sands- Vo. 219, whirh is the fincsl material mathered at lore rest of a dunr, and fo. 245 , irom a blown tirlel.

it Cioldman, M. I., Petrographice vill nee on the origin ol the (atahouli sandst our of Texas: . In. Jour, Nei., th sw.r., vol. 39, p. 269, 191 j.

is ['dilen, J. A., Mechanical composition of clastic sediments: 1ieol. Soc. I merica IBull., vol. 25, pp. 6.55-i\$1, 1915. 
On the other hand, the majority of samples of what be calls incipient wind-hlown sand, which is sand blown out of other deposits, have this composition, as do also his lee sands, which are the finer material lolown beyond the body of a dinne.

Wiroscomir cramination.-(I) Thin section: Three char acters are conspicuous in the thin section of the original rock, namely, (a) its porosity, which is evidently primarythat is, not produced by grinding the thin section-and is a character of wind-deposited material; ${ }^{16}(b)$ the angularity of most of the grains; (c) the absence of a recognizable deposit of serondary quartz on the outside of the grains. In many casps it can lee detinitely proved, by the presence of inclusions thronghout the grain, that there is no outer coat of seconclary ruartz. and the rough angularity of the grains does not suggest secondary growth, which tends to restore crystal form, hut, if anything, rather solution. (II) Disintegratel sand: The disintegrated material can he studied to greater adrantage because it can be immersed in hiquids of different indices of refraction. Thus by inmersing in a liquicl of index about 1.55 the inner strueture of the quartz grains and any possible boumdary between nucleus and secondary quartz can he more readily recognized. Immersing in a liquid of index about 1.65, on the other hand, hrings out hrilliantly the surface form and texture. Nuch more could be observed. especially in the latter liquid, than the time at my disposal permitted. but I can make the following generalizations (a) None of the portions, not even the coarsest, reveal any unusual abundance of rounded grains; rather the opposite. (b) The surface of grains is not frosted, as is characteristic of wind-blown sand, nor pitted, as if subjected to much solution, but rather rough and chipped-looking, as might be the result of mechanical wear. (r) Under the favorable conditions afforded hy immersion in a liquid of index about 1.55 , no secondary silicification could be deterted. (d) In the finest size a few very small well-rounded grains were found, the smallest having a diameter of about 0.025 millimeter and being exceptionally perfeetly rounded. Such a grain could probably be proluced only by prolonged wind action. ${ }^{19}$

The main problem of fact, in spite of these observations, still concerns the cause of the present form of the grains. Secondary silicification is often very veiled, and in the absence of comparative studies I am not prepared to conmit myself as to the possibility of solution having acted on the grains. These two fartors affect not only the form but also the size of the grains. However, the coherence of the olservations made favors the belief in their correctness. They lead to the following conclusion:

The jortion of the (heyenne sandstone represented by this sample is nothing like an colian deposit. in an arid region, nor even a part of a permanent dune area in a humid climate, but merely an accumulation of material blown by the wiud out of a sleposit of some other origin. ()nly an extensive field study could disclose the main accumulation from which this is separater and other possible associated facies and lead to a complete and satisfactory interpretation. From the roughness of the sand grains I would be inchined to assume rather a delta than a beach deposit as the dominaut type. The very

16 Goldman, M. 1., op. cit., pp. 2s0-241.

17 Idem, pp. 271-272. small, periferly rounded grain noted appears entirely out of place as the prorluct of the conditions under which the sandstone secms likely to have been formed and must therefore be assumed to be the product of an earlier cycle in the history of the grain, unless it is assumed that in a defosition of secondary silica the larger grains have been favored so that only the smallest grains retain their original form; but this seems to me incompatible with the uniform size of the larger grains.

Is lrought out in the pajer on the Catahoula sandstone there are many more factors that might have been consilered, but being limited in time and having no assistance for such work I have selected the few that seemed most rapidly determinable and most important.

A single sample whose position in the local section is unknown can be conclusive only for that one sample. The foreset bedding of which I have seen pictures suggests delta deposition, but no one has made field studies of the Cheyenne sandstone with the object of determining the origin of the sediments or the method of sedimentation, and Mr. Goldman's report is therefore chicfly significant in indicating what definite results might be obtained in this region of an oscillating Cretaccous strand by a careful study of the problem.

The plants and their method of occurrence conclusively indicate a sparse regetation, at least seasonal dryness, and accumulation by the wind. This I an sure was a local condition, as previously stated. Whether these facts do or do not indicate heaches, interstream sand hills, or delta deposits can be determined only ly future studies.

\section{AGE OF THE FLORA.}

Ignoring for the present the general relations and the implications resulting from the age of the orerlying Kiowa shale or the supposed equivalent beds in Texas, as discussed in the preceding section, and considering only the evidence of the fossil plants, I may note that ten of the 23 species are positively identified as "Dakota" forms and two additional species are tentatively so identified. Four others are peculiar to the Cheyenne sandstone. The type localities of the remaining soren species were the Cenomanian of Bohemia (one species), the Atane beds of Greenland (two species), and the Patapsco formation of Maryland (four species).

Of the so-called Dakota forms in the Cheyenne flora the following species were previously known from only the "Dakota": Cladophlebis dakotensis (Lesquereux), Cycadeospermum line- 
atum Lesqueleux, Séquoia condita Lesquereux, Abithes emestinar lesquerenx, strreulin mucronate Lespucreux, and Sassufres mudyii Lesquereux. Of these the first two were fonnd near Delplos, Kans.; Srquoia condita, one of the most abundant forms in the Cheyenue sandstone, was known simply from "Linsas" and might really have come originally from the Cheyeme simdstone; Abiftes eruestina was from Decatur, Nebr.; Strenlia mucronata was from Ellsworth County, Lans.; and Siassefres mudyii was recorded from Salina River, Lans., and livans (puarey, S. Dak. Aceording to Stanton the outcrops of the Dikota sandstone at Delphos, in Ellsworth ('omnty, and nlong Salina River, in Kansas, and at Decatur, Nolor., are in the upper part of the Dakota, the berls at Decatur heing within 300 feet of the top. Hence the species common to these localities fend to emphasize the transitional character of the Cheyeme flora.

Five of the remining six species common to the Dakota are of still more value in that they have all been recorded from other regions where the age is less a matter of doubt. The sixth, Asplenium diclisonianum Heer, is of slight value in this connection, as it is prohably a composite species. It has been recorded from both older and younger formations, namely, Tuscaloosa, Raritan, Patapseo, Lakota, Kome, Atane, Kootenai, and the Upper Cretaceous of Sakhalin Island. Gleichenia nordenskioldi was described originally from material collected in the Fome beds of Greenland and identified by Lesquereux in specimens from the Dakota at Fort Harker, Kans. I lrave identified the Cheyenne sandstone specimens as this species becanse they are identical with those described under that name by Les(puerenx, but neither these nor Lesfuereux's specimens can be distinguished from another of Heer's nominal species of Gleichenia, namely, Gleichenia zippei, which has been recorded all over the Northern Hemisphere at horizons ranging from Lower ('retaceous to Senonian and has been found in the Atluntic Coustal Plain in the Raritan and Magothy formations. Abietites longifolius ranges throngh the l'otomac group of Maryland and Vilginia and is found in the Raritan fomation in New Jersey and in the Fuson formation of the Black Hills. Sapindopsis maynifolia is a Patapseo species, Sterculia towneri (Lesquereux) is found in the
Magothy formation, and Aratiopsoides cretacra (Newherry) is foumd in the Raritan and Magothy formations of the Atlantic Constal Plain.

1 prominent alement in the chorenne sandstono llora consists of the three nominally distionet speciess of sapindopsis, which are equally prominent in the Patapsco formation of Maryland and Virginia. One of these is also probably present in the true (hater) Dakuta flora, ame another has been lecorded from the Fuson formation of the Black llills, althourl the lattor is not entirely ratracteristic. This comsideruble Patapsen clement in the Cheyenne flura is of considerable interest, for it includes, in addition to the abundant remains of these threc species of Sapindopsis, a characteristic Abirtites (A. Longifolins). These three forms of Sapindopsis are distinguished chiefly by the size of their leaflets and probably in both floras represent sliglit varjalts of a single botanic species.

The Patapsco flora has been rather definitely' correlated with the Albian stage of Europe. is I do not regard the community of Sapindopsis and Ibivtites in the Cheyeme and Patapseo as indicating synchroncity, for the following reasons. The Patapsco flora contains 41 species that persist into it from the older Lowror Cretaceons. Only one of these, the Abietites, oceurs in the Cheyenne, and it is also present in the Atane beds of Greenland and the Raritan formation of New Jersey. The Patapsco flora numbers 83 speries, and of this large number only two have been fomd in the immediately overlying Raritan formation. Neither of these oceurs in the Cheyenne.

The Cheyenne entirely lacks the older elements that serve to distinguish the Patapsco from the Raritan and stamp its age as Albian. For exumple, the following forn genera of the Patupseo are not found in the Chesenne: liuffordia, Acrostichopteris, hnoultonella, Cladophlebis, Iryopteris, Onychiopsis, Sagenopteris, Tempskya, Scleropteris, and Thinnfeldia; the following cycadoplyte genera of the Patapsco are not foumd in the cheyenne: Conopteris, Zamiopsis, Vilsonia, Zomites, Dichotozamites, and Podozamits; and the following comiferophyte genera of the Patapseo are not found in the Cheyenne: Nagciopsis, Brachyphyllum, Arancarites, Pinus, Frenclopsis, Sphenolepis, 19 Berry, L. W., Maryland Geol. Survey, Lower Cretaccous, D. 172,
1911. 
and Middringtonites. The rast majority of these alle old wenera which became extinct before the dawn of the Upper Cretaceous and which gire the Alhian facies to the Patapsco. Even as regards the angiosperm element of the Patapsco, which might be expected to show more similarities to only slightly younger formations, the following genera of the Patapseo are not represented in the Cherenne: Cyperacites, Plantayinopsis, Alesinaphyllum, Populus, Populophigllum, Velumbites, Jenispermites, Colastrophyllum, C'issites, Aralinephyllum, Hederaephyllum, and Aristolochinephyllum.

The angiosperms of the Cheyenne flora, comprising only eleven species of six genera, contain but two genera that are found in the Albian (Śapindopsis and Sassafras).

Moreover, the Cheyenne flora entirely lacks those supposed Dakota sandstone species which are common in the Woodbine sand of Texas, the Bingen sund of Arkansas, the Tuscaloosa formation of Mlabama, and the Raritan, Magothy, and allied formations of the Atlantic coast region and which clearly show that the so-called Dakota flora as it stands in the literature is not a chronologic unit and that there is a Dakota sandstone which is approximately of the same age as these formations and which I am inclined to consider of Turonian age according to European standards.

I regard the Cheyenne flora as clearly of the same general facies as those of the Lpper Cretaceous formations that immediately succeded the Cheyenne sandstone in time and as set apart from any known Lower Cretaceous floras by the absence of the characteristic Lower Cretaceous element in part exemplified by the Patapsco generi of ferns, cycads, and conifers enmmerated in a preceding paragraph.

The Cheyenne flora is unquestionably older than the flora of the Woodbine sand of Texas, for although the latter also consists largely of so-called Dakota forms there is not a single species that is common to the Cheyenne and Woodbine, and the "Dakota" speries of the Woodbine are nearly all the common forms of Coastal Plain formations of known age. I have recently completed a study of the Woodbine flora, ${ }^{19}$ so that these statements are authoritative.

The range of the plants found in the Cherenne sandstone is given in the appended table of distribution.

Listribution of flora of Cheyenne sandstone.

Cladophlehis dakotensis (Lesquereux)

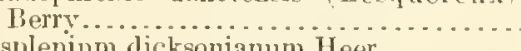

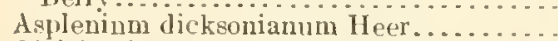

Gleichenia nordenskiöldi Heer.

Gleichenia? hohenica (corda) Berry

('ycadeoidea munita ('ragin

Cyradeospermum lineatum Lesinereix...

Sequoia condita Lesquereux.

Cupressinoxylon cheyennense Pentuallow.

Abietites ernestinae Lesquerenx.........

Abietiles longifolius (Fnntaine) Berry.

Arumdo groenlandira Heer?.

Sapindopsis variabilis Fontaine

Sapindopsis mannifolia Fontaine.

Sapindopsis lrevifolia lontaine.

Slerculia towneri (Lesquereux) Berry.....

Ster"ulia mucronata Lesuluereux. . . . . . . .

Sassairas mudgi Lesquereux.

Aralia ravniana IJeer.

Aralia polymorpha Newlierry.

Araliopsoides retacea (Newierro) Berry.

Carpolithus hel viderensis Terry

Feistmantelia oblonga Wari...

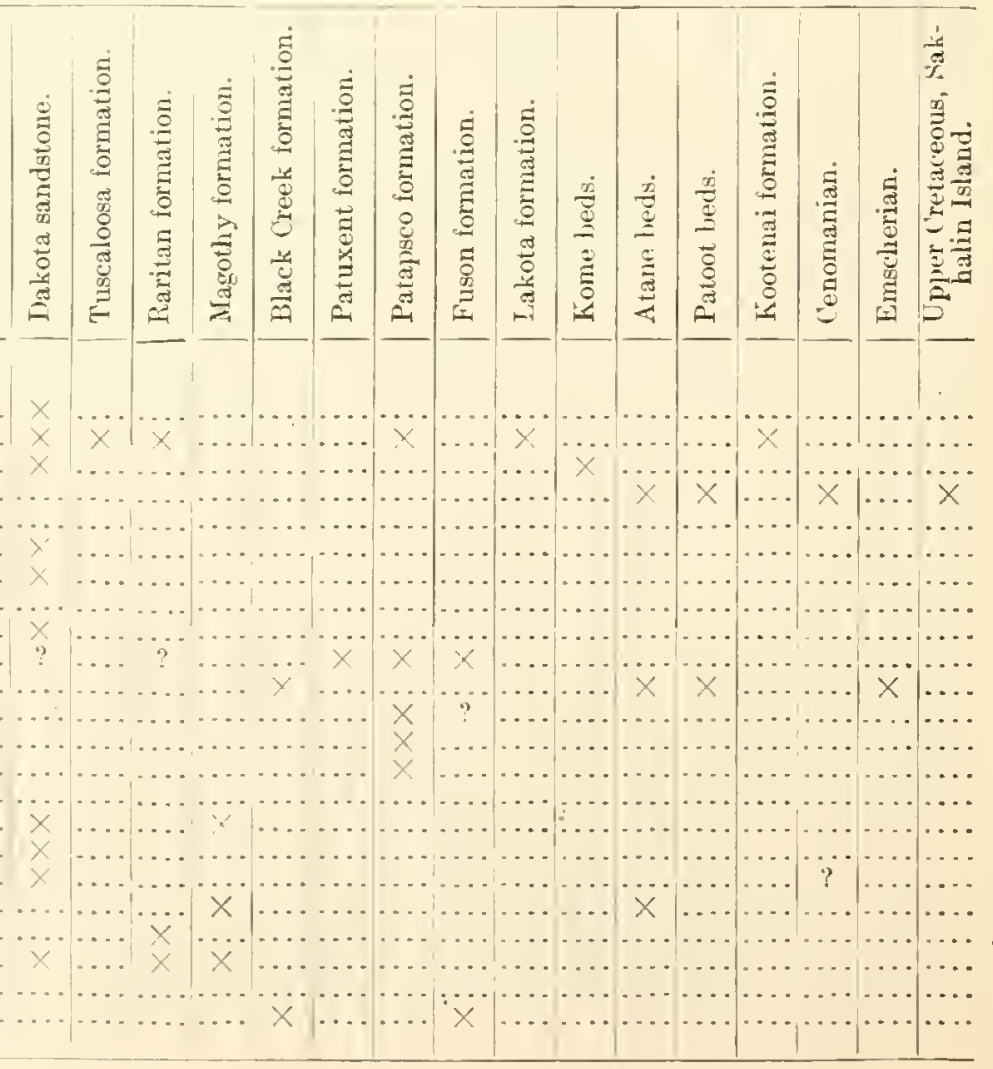




\section{SYSTEMATIC DESCRIPTIONS.}

Phylum PTERIDOPHYTA.

Class IEPTOSPORANGIATAE.

Order POLYPODIALES.

Family POLYPODIACEAE.

Genus CLADOPHLEBIS Brongniart.

Cladophlebis dakotensis (Lesquereux) Berry.

Perris dutotensis I enguereux, U. S. Geol. Survey Mon. 17 (Flora of the l)akota group), p. 24, pl. 1, figs. 2, 3 1892.

This species, the type material of which was collected 10 miles northeast of Delphos, Kans., was described as follows by Lespucreux:

loimate pinnae linear-lanceolate, pinnatuly deeply cut into oblique equal suboprosite lanceolate bluntpointed and subfalcate pinnules, connate above the hase, entire, close but disconnected aloove; median vin thin, distinct; secondaries opposite, 6-7 pairs, simple, curving upward in passing to the borders.

This form is obviously to be referred to the genus Cladophlebis, which wus so abundant during the Mesozoic cra. It was referred to Pterie by Lesquereux, as was the habit among earlies palcobotanists. The material which Lesquereux had and that from the Cheyeme sandstone are both too meager for critical comprarisons with other alescribed species of Cludophlebis. The two specimens from the Cheyenne sandstone came from Thompson Creck near the Flume, 2 miles northwest of Belvitere (2221).

\section{Genus ASPLENIUM Linnế.}

\section{Asplenium dicksonianum Heer.}

Asplenium dicksonianum IIeer, lilora fossilis arctica, vol. 3 , Abt. 2, p. 31, pl. 1, figs. 1-5, 1874; rol. 6, Abt. 2, pp. 3,33 , pl. 2, fig. 2 ; p). 32 , figs. 1-8, 1862.

Dawson, Roy. Sor. Canada Trans., vol. 1, ser. 4, p. 11, 1883 ; vol. 3 , ser. 4, p. 5, pl. 3, fig. 1, 1S55; Canada Geol. Survey Ann. Rept., new ser., vol. 1, 1). 7f, 1S56; Roy. Soc. Canada Trans., vol. 10, sec. 4, p. 91, 1892.

Lesquereux, The flora of the Dakota group, p. 24, pl. 1, fig. 1, 1892.

Newberry, The flon of the Amboy ('lays, 1. 39, jl. 1, figs. 6,7 ; pl. 2, figs. 1-8; 1). 3, fig. $3,1896$.

Ward, U. S. Geol. Surver Nineternth Ann. Rept., pt. 2, p. 704, pl. 170, fig. 1, 1899; Jour. Geology, rol. 2, pp. 259, 261, 1894.

Foutaine, in Ward, U. S. Geol. Survey Nineleenth Ann. Rept., pt. 2, p. 664, pl. 162, figs. 6-8, 1599 (not Fontaine, 1888).

Kurtz, Contribuciones á la palacophytologia argentina, 111: Ilus. la Plata Rev., vol. 10, 1. 19, 1s99 [1902].
Ber:y, Torrey 13ot. ('lub lisll., vol. 3S, 1). 409, 1!11; New Jersey ficol. Sursey Bull. 3, 1). 65, pl. 5, lies. 3, 4, 1911; Maryland feal. Survey, Cppor Crelaceous, p. 76\%, I916; U. S. Cieol. Survey l'rof. Papr $112,11.53,1919$.

This species was deseribed by Heer in $1 \mathrm{~s}$ t from mnterial found in the Kome bels (Lower Cretaceous) of Ciremlanel. It was substquently identified hy Ileer in material from the much Iater Atano beels (I Pper ('retaceous) of Greenland: Dawson reported it from a number of localities in the Footenai formation (Lower Cretaceons) of British Columbia, although these records are questionable: and Fontaine and Ward described it from specinens obtained in the Lower Cretaceous of the Blarek Hills. It is also reported hy both lesquereux and Wald from the Dakota sambtone, and by Kurt\% from drentina. It seems very doubtful if these sperimens (an all be the same plant, and the geologic range alone suggests that the earlier and the later forms may be distinct. The Lower Cretareons forms certainly suggest a relationship with those widespread types of sterile fronds variously identified as Thyr*opteris or Onychiopsis, and they may be compared with Onychiopsis yocpporti (Sidhenk) Berry. The L Pper Cretaceous forms suggest Anemia rather than Asplenium and are much like the widespread Eocene species Inemia haydenii (Lesquereux) Cockeroll and Anemia subcretacca (Saporta) Gariner and Ettingshausen. Howevor, in the absence of representative material from the diflerent horizons, it seems unwise to attempt any segregation at the present time, and the synonymy is cited in full for the use of some future student who may have aceess to enough material to enable him to make an aceurate revision and segregation of this so-ealled species. Ittention should also be called to its resemblance to the form oceurring in the [pper Cretacesus of Creenland, the Raritan formation of New Jersey, and the Tuscaloosa formation of Alabama which goes by the name Dichesonia yroenlandica Heer, although the ground for considering it a Dicksonia is entirely inconclusive.

Besides occurring at the localities named above the present species is abundant in the Raritan formation of New lerser and Martland, and material that is absolutely identicul with the Now Jorsey Raritan nuterial which I have seen and with that from the l)akota sandstone is present in the 'Tuscalousa formation of 
Alabamia and the Cbevenne sandstone of southcru Linsas. I have recently leceived a fine sperinen fiom northeastern New Mexico from a sandstone that appears to represent the Purgatuire formation.

"The specimens from the Che renne sandstone, all of which are frugmentary, were found in brown clay in a draw on Medicine Lodge Creek, 3 miles abore Belvidere (collected by Ward and Vanghan, 1896, no number): $1 \frac{1}{2}$ miles northwest of Belvidere (2215); near Medicine Lodge Creek, 2 miles west of Belvidere (222t, same locility as that first (ited); and $2 \frac{1}{2}$ miles due west of Belridere (2226).

\section{Order GLEICHENIALES.}

\section{Family GLEICHENIACEAE.}

\section{Genus GLEICHENIA Smith.}

Gleichenia nordenskiöldi Heer. ${ }^{20}$

Plate XLVII, figure 1.

Gleichenia uordenstiöldi Heer, Flora fossilis arctica, vol. 3, Abt. 2, p. 50, pl. 9, figs. 6-12, 1574; vol. 6, Abt. 2, p. \&, pl. 1, figs. 1, 1a, 1882.

Lesquereux, U. S. Geol. and Geog. Survey Terr. Ann. Rejt. for 1574, p. 334, pl. 2, fig. 5, 1876; Cretaceous and Tertiary floras, p. 26, pl. 1, figs. 1, 1a, 1883; U. S. Geol. Survey Mon. 17, P. 25, 1892.

This species was described originally by Heer from material collected in the Kome beds of western Greenland. Species of Gleichenia are rery abundant throughout the Cretaceous section of that region, and Heer founded rery many species on this material, more than seen waranted. The stratigraphic boundary between the Kome and Itane beds has been shown by subsequent workers to be rery indefinite, and the Atane beds are present at the Kome locality, a fact which may account for the range accredited to a large number of the species.

Lesquereux subsequently ilentified Gleichenia nordenstiöldi from the Dakota sandstone at Fort IIarker, Kans. His material was not rery convincing and perhaps should not have received a specific name. Material

${ }^{20}$ The following do not belong to this species:

Glichenia nordenskiöldi Fontaine, 1. S. Geol. Surrey Mon. 15, p. 119, pl. 21, fig. 11, 1590.

Gleichenia mordenskiäldi Fontaine, in Ward, U. S. Geol. Survey Mon. 4s, p. 231, pl. 65 , figs. 24-29, 1906 .

Pezopteris strictinert is Fontaine. Fontaine, in Diller and Stanton, Geol. Soc. America Bull., vol. 5, p. $450,1 \$ 95$; in Stanton, U. S. Feol. Survey Bull. $133,1 \times 95$, p. 15 , [1*4t6].

Aspidium hetcrophyllum Fontaine. Fontaine, in Diller and Stanton, op. cit., p. 450; in Stanton, op. eit., p. 15.

asmunda dicksonirides Fontaine. Fontsine, in Diller and Stanton, op. cit., p. 450; in Stanton, op. cit., p. 15. identical with that of Lescuereux is not uncommon in the Cheyenne sandstone, and I have used the same name for it, although it should be borne in mind that neither Lesquereux's material nor mine is distinet from what has commonly been called Gleichenia zippei Heer, ${ }^{21}$ which has been identified, often wrongly, I believe, at a large number of localities and horizons.

The unwarranted determination of unidentifiable seraps by $\mathrm{T}$ ard and especially by Fontaine has almost completely obscured the stratigraphic ralue of any material that they described. The specinen from Dutch Gap, Va., which Fontaine referred to this species not only differs from the type material but might readily represent the terminal portion of half a dozen different Patuxent species of ferms. Similarly the specimens from the Knoxville formation which Fontaine referred to Glriclenia nordenskiöldi are not only not that species but they are not eren all the same thing, and the fact that these identical fragments were also referred by Fontaine to Pecopteris, Aspidium, and Osmunda, as well as to Gleichenia, is a fitting commentary on both the character of the material and the critical value of Fontaine's results.

What I have called Gleichenia nordenskioldi is found in the Cheyenne sandstone in clay $2 \frac{1}{2}$ iniles due west of Belvidere (2226), also described as a draw on Medicine Lodge Creek, 3 miles abore Belridere (fem bed, no number), collected by Ward and Vaughan in 1896.

\section{Gleichenia? bohemica (Corda) Berry.}

Plate XLV'11, figure 2.

Pecopteris bohemica (orda, in Reuss, Versteinerungen der böhmischen Kreicleformation, p. 95, pl. 49, fig. 1, 1546.

Heer, Flora fossilis arctica, vol. 3, Abt. 2, p. 96, pl. 26, fig. 17a. 1874; vol. 7, p. 6, pl. 5s, fig. 4, 1853.

Engelhardt, Naturf. Gesell. Isis in Dresden Abh., 1891. No. 7, p. 86.

Kryshtofovich, Coll. Sci. Imp. Univ. Tokyo Jour., vol. 40, art. 8, p. 31, fig. 2. 1918.

This species was described by Corda in 1846 from material obtained in the Cenomanian of Bohemia. It was subsecpuently recorded from the same lorizon in Saxony. Heer referred a number of Greenland specimens to it, and lately Kryshtoforich has recorded it from the Upper Cretaceous of Sakhalin Island. If these 
records all represent the sume species, it was evidently a widranuging type in the earliest stage of the Lpper Cretaceous, which spread from the Aretic region southwarl into North America, Europe, and Asia. There are five specimens in the Cheyenne sandstone that appear to be identical with Heer's Greenland forms, but as they are preserved in a coarse sandstone their detailed phatrateristies are obliterated. The pinnules are coriaceous, long, and narrow and somewhat resemble what Heer ${ }^{22}$ called Cileichenia rigida.

Although details of frond habit and fructificution are lacking I have rentured to transfer this form from Pecopteris to Cleichenia, as it appears to be congeneric with the numerous Cretaceous forms of that genus.

It was found in the Cheyenne sandstone on the left bank of the middle branch of Champion (Wildeat) Draw, half a mile south of Belvidere (22:29).

\section{Phylum CYCADOPHYTA. \\ Order CYCADEOIDALES. \\ Genus CYCADEOIDEA Buckland. \\ Cycadeoidea munita Cragin.}

Cycadeoidea munita 1'ragin. Washburn college Lab. Dat. Hist. Bull., vol. 2, 1. 6.5, 1589.

Ward, U. S. Geol. Survey Nineteenth Inn. Rept. pt. 2, p. 541, 1899.

Hill ${ }^{23}$ states that there is some doubt as to the occurrence of this specimen at this horizon. Lestel F. Ward, who subsequently visited the locality, states that he was satisfied that it could not have come from the Cheyenne sandstone but may have wealhered out from the overlying "Reeder sandstone." The material, which is only a fragment, has never bocn studied by a competent person, although Ward states that it is surely a fragment of a cyead trunk.

Whaterer its true horizon it is of interest as one of the latest authentic oceurrences of this type of plant.

\section{Genus CYCADEOSPERMUM Saporta.}

Cycadeospermum linealum Lesquereux.

Cycadeopsermum lineatum lesquereux, U. S. Ceol. Survey Ilon. 17, p. 30, pl. 1, fig. 14, [891 [1892].

This seed, which was found 10 miles northeast of Delphos, Kans., was described by Lesquereux as follows:

2 Heer, Oswald, Flora fossilis arcica, vol. $1, p, 40,[1,44$, fig. l, I wis.

23 Hill, R. T., Am. Jour. Sei., 3d ser., vol. 31), p. 212, 199.
Seet oblong-ovato, slightly falcate, rounded at the lower end, short arominate at the other, festa smenth, iransversely lineafe, the fines distaul, parallel; carrna clearly marked longiludinally on lorh siles, the imnor concave, the outer roumled.

length 1 to 1.5 centimoters; width about 6 millimelers, somewhat compressed. Tratil thick, shining, and ligneous.

Crablophyte seeds are not so inequilateral, and the present form is probubly angiospermous. This genus was proposed for Jurassic forms. of which many have been described. 1 few have been described from both Lower and Upper Cretaceous material. The Cheyenne form is rertainly identical with Lesquereux's 1ype. Whether or not it is congeneric with the other species referred to Cycadenspermum, or whether indeed it represents the seed of a cycadophyte and not an angiosperm, can not be defermined. My impression is that it belongs to the latter rather than the former.

Material identical with Lesquereux's type is found in the Cheyenne sandstone $1 \frac{1}{2}$ miles northwest of Belrilere (221S) and near Medicine Lodgr Creek, 2- mikes wess of Belridere (2224)

\section{Phylum CONIFEROPHYTA.}

\section{Order CONIFERALES.}

\section{Family CUPRESSINACEAE.}

Genus SEQUOIA Endlicher.

Sequoia condila Lesquereux.

Plate XIXIII, figures 1-1I.

Siquaia condita Lesquereux, L. S. Geol. and Geol. Survey Terr. Bull., vol. 1, p. 391, 1875 [1S76]: Ann. Repr.

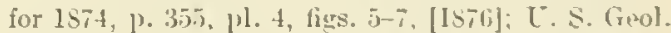
Survey Torr. Rept., vol. S (Cretaceous and Tertiary floras), p. 32, pl. 1, figs. $5-7,1533$; in Cook and Smock, lieport on clay deposits in New Jersey. [P. $29,15: 5$.

The inextricable confusion that results from the irlentification of detached fragments of conifcrous foliage when they ean not be checkerl by fruits or in some other way is well illustrated by the forms that are rariously referred to Glyptostrobus gracillimus Lesquereux, sequnia aracillima Newberry, Widdringtonites reichii Heer, etc. In rolume 6 of the final reports of the [nited States Geolugical surrey of the 'Territories Lesquereux gare figures of a plant which he had named some vears earlier $G l y p(0)$ strobus gracillimes and which he compared with Frenelites reichii of Ettingshausen. When 
Newberry described the flora of the "Amboy day" (Raritan formation) he renamed Lesquerenx's spercies sequoin yracillima because he found assuciated witly similar foliar remains in New Jersey alongate cones with scales resembling those of a Sequoia. He commented on the resemblance of these cones to Geinitzia, but the inater rested here until I compared specimens of the so-ealled Sequoia gracillima cones with those of the European Geinitzia formosa Heer and found the two to be identical. In the European Upper Cretaceous these cones were found attached to foliage of a very different type from Glyptostrobus yracillimus or Sequoin gracillima, although in America the cones were always detached. Foliage like that of Geinitzia formosa was found, howerer, associated with them. It seemed obrious that the cones referred to Sequoia gracillima were those of Geinitzia formosa, and accordingly I so assigned them. I had eollected hundreds of these cones and had abundant comparative material. When I revised the Raritan flora I had much larger collections than those of Newberry, and I found that the foliage which he had called Sequoia gracillima was identical with what he had identified as Wildringtonites reichii (Ettingshausen) Heer.

These remains are abundant in the Atlantic Coastal Plain as far south as Alaloma and have never been found with orulate cones, although the staminate tones are not uncommon. Thus the slender conifer in the last is IViddringtonites. Whether Lesquereux's Glyptostrobus yracillimus also represents this genus or not 1 do not know. I suspect that in spite of minor and not very obvious differences Glyptostrobus yrucillimus is none other than Sequoia condita, which Lesquereux deseribed in Hayden's report for $187+$ from rery incomplete material collecterl at Fort Harker and Clay Center, Kins.

The most alyundant plants in the Cheyeune sandstone are graceful, delicate coniferous branches bearing numerous distinctive cones identical with the one referred to Sequora condita by Lesquereux, as is the folinge, which has been recorded in the literature of the Cheyenne sandstone, as Glyptostrobus gracillimus (Ward) and Sequoia gracillima (Knowlton). The collections naturally contain many specimens of detached cones and many specimens of foliage lacking cones, hut the evidence is as strong as it can possibly fe that when cones and foliage are found in union in a dozen specimens those that are found separated in the same bed are none other. I have specimens of eones from six localities and of the foliage from thirteen localities around Belvidere.

Moreover, the foliage shows consilerable variation in the extent to which the leaves are pointed or obtuse, appressed or spreading, depending not only on a natural amount of rariation but also on whether it represents shoots of the year or older twigs, and furthermore the appearance differs greatly with the nature of the matrix, the extent to which iron salts have heen depositel along the channels formed by the twigs, and other conditions. The specimens found in the sandstones appear different from those found in the clays, and some specimens in the days which were much incrusted suggested at first sight the genus Brachyphyllum.

Before describing the species as fully as the large collection studied permits, I would like to point out that Sequoia condita is not related to Widdringtonites, Juniperus, Glyptostrobus, or Sphenolepis-genera in which the foliage is comparable-and it is perfectly distinct from Sequoia fastigiata. It is known only from the Cheyenne sandstone and from the true Dakota of Kinsas. In the absence of attached cones the foliage might be referred to any one of several genera, or its variants might be referred to several different species in as many genera. Taken together, they demonstrate that it is a Sequoia, and I do not feel the slightest loubt but that all the material from the Cheyenne sandstone represents a single botanic species. It may be lescribed as follows: Twigs rather rigid, pinnately branched, slender elongate; corered with small, decurrent, crowded leaves varying from appressed to spreading falcate, thick and coriaceous, acute or obtusely pointed, slightly keeled but without rein. The leares are arranged in a spiral phyllotaxy which becomes higher with the elongation of the twigs. In old twigs 2 to 3 millimeters in diameter they are scattered, spreading, and falcate. Their blunt tip is more apparent tlam real and is due to their usual or partial preservation in the form of casts. The variations in appearance are well shown in the accompanying figures. The cones vary from prolate to nearly spherical in 
form and consist of about 22 scales spirally arranged, as compared with about 30 in the cones of the modern redwood. The nxis is stout and fusiform. The seales have a thin rounded peduncle expanding distad into a rhomboidal peltate tip only slightly wider than high, with a winkted marginal face surrounding a central laterally elongated umbilicus. length of cone (maximum), 2.4 ceutimeters; diameter (maximum), 1.S centimeters. Arerage size somewhat smaller. Length of scale (maximum), S millimeters; width, 6.5 millimeters; height, 4.5 millimeters. 'These cones are remarkably like those of the existing redwood (Sequoia semperirens) in every respectsize of axis, shape of seales, etc-except that the scales are less numerous in the fossils and the maximun size of the seales is about sixserenths that of the averagc redwood scale. The arerage size of the fossil cones is from two-thirds to fire-serenths that of the modem cones.

The condition of preservation of these cones is a strong argument in favor of the colian character of the sandstone. All have the scales somewhat shriveled and widely separated and are exactly comparable to thoroushly dried redwood cones. They are exceedingly abundant in the sandy phases of the Cheyenne sandstone, as if they had been blown about by winds and aceumulated in hollows. I hare not encountered them in the clays, although the clays contain specimens of the foliage.

Whether or not Sequoia condita oceurs at any other horizons or localities is problematic and can be determined only by the best of evidence, for, as 1 have already stated, the foliage is duplicated more or less closely by a variety of unrelated conifers. In particular the Upper Cretaceous conifer known as Widdringtonites subtilis, a form that I have not mentioned abore, has foliage very like the more slender twigs of Strquoia condita, and in the absence of cones I doubt if the two could be distinguished. Howerer, a single specimen of Widdringtonites subtilis found in the 'Tusealoosa formation of Alabama had small four-ralred cones entirely unlike those of Sequoia condita.

The Cheyenne sandstone loculities are as follows: Cones and foliage, bluck hills near Belridere (773); $1 \frac{1}{2}$ miles uorthwest of Belridere (2218); Champion (Wildeat) Draw, threcfourths mile south of Belridere (2222); near
Medieine Lodige Creek, 2 miles west of Belvidere (2224): left loank of middle bruncl of Champion (Wildeat) Draw, half a mile south of Belvidere (22:4): right lank of sance draw (2231): Osage Rock, near Belvidere (7406). Foliage only, Stokes Hill, 100 vards south of National Corral (2219): "Lanphier shales" in Champion (Wildeat) Draw, three-fourths milo south of Belridere (2223): "Lanphicr shales" in a (lraw 1 mile southwest of Belridere (2225); hills between Spring Creek and Soldier, $\&$ miles northeast of Belvidere (2225); Champion (Wildeat) Draw, right (east) branch, half a milc south of Belridere, in "Lauphier slunles" (2228); first draw west of Champion (Wildeat) Draw, half a mile south of Belvidere (2233).

\section{Family ABIETINEACEAE}

\section{Genus ABIETITES Hisinger}

Abietites longifolius (Fontaine) Berry.

Ilate XIX'll, figure 3.

Abietites longifolius (Fontaine) Berry, U. S. Nat. Mus Proc., vol. 40, 1. 315, 1911; Maryland Geol. Survey, Lower Cretaceous, p. 407, pt. 67, fig. $7,1911$.

Leplostrobus longifolius Fontaine, U. S. Geol. Survey Mon. 15, p. 228, j)l. 101, fig. 2; pl. 102, figs. 1- ; pl 103, figs. 6-12; pl. 104, fig. 6. 1890; in Ward, L. S Geol. Survey Nineteenth $\mathrm{Ann}$. Rept., pt. 2, p.671, pl. 163, fig. 15; pl. 165, fig. 3, 1899; U. S. Geol Survey Mln. 48, pp. 281, 481, 482, 491, 506, 528, 557, pl. 110 , fig. 11 , pl. 116 , fig. 1, 1906 .

Leaves narrow, needlelike, 10 to 15 centimeters in length, aggregnted in bundles. Bundles apparently horne on sliort shoots, with ninny leaves in each bundle. No satisfactory venntion can be inade out. Fontaine described a number of reins in these forms, but as nearly as can be detcrmined these are simply folds due to compression or the angles of the lenf.

This species lans a considerable geologic as well as geographic range, having been recorded from the Fuotenai formation of British Columbia, the Fuson formation of the Black Hills, and the Potomac group in Muryland and Virginia. In the Potomac group it is of frepuent oceurrence and individually abundant, being found in the oldest as well as the youngest beds, hut uuch more commonly in the latter. The remains are always poorly preserved and were eridently mueh macerated before fossilization. They are closely comparable with Pinites solmsi Seward, of the Wealden, and with Pinus peterseni Heer, from the Kome 
beds of Greenlaud. They appear to be identical with specimens from the Itane beds of Greenland which Horer ${ }^{2}$ deseribed as Pinus varinalis. I have not, lowerer, inchided the latter in the foregoing synonym as it is an carlier nane and would involve changing the well-known and highly characteristic name longifolius.

These remains are very common in the Cheyenne sandstone. Similar forms under different specific nancs are common and wideranging at Lower and Upper Cretaceous horizons in North America, Europe, and Asia.

The Cherenne sandstone localities are black hills near Belvidere (773); $1 \frac{1}{2}$ miles northwest of Belvidere (2218); Thompson Creek near the flume, 2 miles northwest of Belridere (2221); Champion (Wildeat) Draw, three-fourths mile south of Belvidere (2222); 1 mile southwest of Belvidere (2225); left bank of middle branch of Champion Draw, half a mile soutl of Belridere (2229); and right bank of same branch (2231).

\section{Abietites ernestinae Lesquereux.}

Abirtites ernestinae Lesquereux, U. S. Geol. Survey Terr. Rept., vol. 6, p. 49, pl. 1, fig. 7, 1874.

Pterophyllum haydenii Lesquereux (part), An. Jour. Sci., $2 d$ ser., vol. 46, p. 91, 1868

Lesquereux characterized this species as follows:

Cone oblong, abruptly narrowed to a short pedicel, scales broad, truncate, appressed, and imbricated in spiral.

This diagnosis obriously has nothing that would serve to set it apart from what might be written of dozens of fossil cone fragments of diverse relationships. The species was deseribed from fragments collected near Decatur, Nebr., and similar cone fragments are present in the Cheyenne sundstone. They are not to be distinguished from other so-called species which I have referred to the genus Abietites of Hisinger..$^{25}$

This genus is a conrenient and useful repository for fossils, both strobilar or foliar, whose real or fancied affinities are with the modern Abietinaceae. These ringe in age from the Reuper to the Pliocene, though the bulk came from the Cretaceous, and they comprise obscure impressions of foliage and cones, none of which lave any real biologic value or present any

24 Heer, Oswald, Flora [ossilis arctici, rol. 3, Abt. 2, p. 103, pl. 27, fig. $15 \mathrm{~b}, 1 \mathrm{1}-\mathrm{t}$.

as Hisinger, W., Lethaes suecica, p. 110, 1s3i. definite due to their true relationship. Fontaine has included in this genus fossils from the Triassic of North Carolina and various indefinite remains from the Trinity group of Texas, the Shasta series of California, the Lakota sandstone of the Black Hills, and the Potomac group of Maryland and Virginia. The Potomac fossils he segregated into four species, all of which were based on obseure cone impressions and none of which possess much specific ralue. When it is remembered what diverse appearances may be assumed by a single species of cone, irrespective of individual rariation, as a result of different stages, of maceration before preservation, of differences in the matrix, and of differences in the threction and force of compression, it seems rery probable that such forms can never be discussed satisfactorily.

Similar forms from the Enghish Wealden and later Cretaceous are described by Carruthers, Gardner, Seward, and others and referred to the comprehensive genus Pinites of Endlicher (1847). They are in all probubility congeneric if not specifically identical with American forms referred to Abietites, and that nume is preferable, as Pinites Endlicher is antedated by Pinites Witham, which was proposed for very different objects.

Abietites cones are also common in the French and Belgian Cretaceous and hare usually been referred to the genus Pinus, although there is slight warrant for such a procedure.

Abietites cones are rare in the Cheyenne sandstone, being known only from Osige Rock, at Belvidere, in the "Stokes sandstone" below the so-ealled Champion shell bed at the base of the Kiowa shate (2232).

\section{Genus CUPRESSINOXYLON Goeppert.}

\section{Cupressinoxylon cheyennense Penhallow.}

Cupressinoxylon chryennerse Penhallow, Roy. Soc. Canada

Trans., 2ll ser., vol. 6, sec. 4, p. 76, 1900 [1901]; Manual of North American gymnosperms, p. 238, 1907 .

This species was described as coming from the Cheyenne sandstone east of Stokes Hill, on the Kiowa-Baker County line, and was collected by Prosser.

There is nothing to be added to the original description of this species, which was unillustrated. Nor is it worth while to quote that description, for it is very doubtful if the form could be recognized again, eren by the author, 
short of comparison with the type sections. There is some doubt as to whother it came from the Cleyenne sandstome. I include it morely for the suke of completeness. In the case of Amacarioxylon prosseri, which Penhallow ${ }^{20}$ recoriled from this region, the data are so entirely uneretain that l omit any further reference to it.

Cupressinoxylon cheyenrense is of some intelest, as Penhallow definitely remarks upon the presence of giowtl rings, which is thus in accorl with my supposition that the region hat an arid clinate and seasonal rainfall.

\section{Phylum ANGIOSPERMOPHYTA.}

\section{Class MONOCOTYLEDONAE.}

\section{Order POALES.}

\section{Genus ARUNDO Linne.}

\section{Arundo groenlandica Heer?}

Arundo groenlandicn II eer. Flora fossilis arctica, vol. 3. Alt. 2. 1. 101, pl. 28, figs. 8-11, 187t; vol. fi. 1lit. 2, 1. 57, pl. 17, fig. 10, 1882; vol. 7, p. 18, pl. 54, figs. 1-3, 1883.

I'rozzi, Soc. ital. sci. nat, Atti, vol. 31, p. 403, pl. 6 , fig. 5, 1858; Šoc. geol. ital. Jioll., vol. 10, p. 376, pl. 1f. fig. 3, 1891 .

Berry, U. S. Geol. Survey Prof. Paper 84, j) 28, pl. 4. fig. 7,1914 .

Striated culms and fragments of long, linear pointed leaves, 2 to 3 centimeters in width. Veins numerous, fine, and parallol.

This identifiention is queried because of the general lack of individuality in remains of this sort. They include the specimens from Belridere that Ward referred to as bamboo-like stems in his discussion of Feistmantelia.

'The speeies was leseribed by Heer from material found in both the Atane and Patoot beds of western Greenland. It was subsequently recordel by me from the Middendorf arkose member of the Black Creek formation in South Carolina and by Bozzi from the Emscherian of Italy. Little relinner can be placed upon records of remains of this sort. however, which also resemble in a general way the somewhat earlier forms referred by Schenk and others to Eolirion.

The Cheyenne saudstone localities are Champion (Wildeat) Draw, shales three-quarters of a mile south of Belvidere (222): hills between Spring Creek and Soldier, $t$ miles northeast of

36 Penhallow, D. P., Roy. Soc. Camada Trans., 21 ser., vol, 6, sec. 4 , p. 77, 1901.

$70351^{\circ}-22-2$
Belvidere (2227): und Champion (Wildeat) Draw, right (east) bunk half a mile south of Belridere ("Lanphier shales," 22:2s).

\section{Class DICOTYLEDONAE}

Order SAPINDALES

Family SAPINDACEAE.

Genus SAPINDOPSIS Fontaine.

Sapindopsis variabilis Fonlaine.

Plate LT, figures:-1

Sapindopsis rariabilis Fontaine, I. S. Geol. Survey .Hon 15, p. 2!1, pl. 151, fig. 1; pl. 152, tigs. 1, 4; pl. 1.33, fig. 3 ; 1)l. 154 , fig8. $2-1$; 1 l. 1.55, fig8. $2-i$, 1s90; in Ward, I. S. Creol. Survey Ninetentl Ann. Lept., pt. 2, p. 6\%0, pl. ]69, fig. 9, 1895; ['. S. Gieol. Survey Jon. 4s, pp. 451, 452, 459, 332, pl. 114, fig. 2, 1306.

Berry, I. S. Nat. Mus. Proc., vol. 36, p. 1itl, 1910; Maryland Geol. Survey, Lower Crelaceous, p. 469, pls. $83,84,85,1911$

Sapindopsis purifolia Fontaine, I. S. Creol Survey Mon. 15, p. 300, pl. $15 \mathrm{l}$, fig. 1 , 1890 .

Eucalyptus rosilriana Ward, IT. S. Feol. Survey Mon. 18, p. 530, pl. 113, figs. 9. 10, 1906.

Ficus muricoilles Ward, idem, p. 531. pl. 112, fie. 12, 1906. Rogersia angustifolia Fontaine, in Ward, idem, pp. 491, $510($ not p. 521), 19065

Leaves odd-pinnate, in some specimens evenpinnats, witl thee pairs of lateral leaflets, which may be opposite, although usually there is a tendency townd a subopposite arrangement, markedly so in several specimens. Leaflets nomally lanceolate, individuals of the same leaf about of a size, usually markelly decurrent, but varable in this respert. The proximal leaflets are always liss decurrent than the pair next abore, and some even have short petioles. The upper leallets are remarkably rariable; some have an abnormal decurrent wing which joins the inner Iamina of the next lower pair of leaflets; in olhers the rachis entirely lacks a wing. The loaf may be teminated abruptly by a pair of leaflets varionsly enaleseed, or the three apical leallets may be rariously united, their laminate may be almost symmetrieal or markedly inequilateral, their margins showing a tendoney toward undulation, and rarely a lentlet is dirided into a basal and an apical part by a sharp constriction on one side near the midclle of the hadr. The specimens range in size from the small forms upon which Fontrine founded his speries S. parvifolia and which are 1.6 centimeters long and 0.4 centimeter wide to forms which upproach S. magnifolia in size and are 10 centi- 
meters long and 1.5 centimeters wide. The nvelage dimensions of a large number of specimors, howerer, are 6 to 7 centimeters long by 1 to 1.3 contimeters widl.

Leares thick, with smooth surface. Rachis and midrib stout. Venation more prominent than in the other species but still rery faint, with the exception of the secondaries, which thougl fine are more conspicuous than in the other species. Secondaries forming a wide angle with the midrib, nearly straight for twothirds of the distance to the margin, where they bend sharply upward and join the secondary next above by a slightly curved arch. As the seconclaries a re numerous and alnost muiformly spaced the renation resembles that of a Eucalyptus except that the marginal hem is mucli broader than in that genus. In fact some of the detacherl leallets were determined by Ward is forms of Eucalyptus, as also was some of the Virginia material of this species.

This species is exceedingly abundant at many localities in the Patapsco formation in Maryand and Virginia and is by far the most characteristic species of that formation, although it has not been detected at certain other undoubted Patapsco horizons. Not especially characteristic material is abundant along Oak Creek, Wyo., in leeds that have been referred to the Fuson formation. This species was also suggested by Cockerell ${ }^{27}$ for some leares from an unknown geologic horizon in southwestern Colorado. I have since exmined this material, which is rery inconchsive, in my opinion. Cockerell infers that sapindopsis may be related to Gnetum, but I cannot see any warrant for such a supposition.

This species is an exceedingly variable form in all its details, and as during maceration the most variable apical portion is the last to be destroyed, this rariahility is emphasized in fragmentary material such as that usually found. When well preserved it furnishes most striking specimens, as may be seen from the specimens reproduced photographically in Plate LV (ligs. 2-4). In life its rigid pinnate leaves and strict appearance must have made it a very striking momber of the Cheyenne flora.

The Cherenne sumlstone occurrences of Sapindopsis variabilis are Osage Rock at Bel-

": Cockercll, T. D. A., Washington Acad. Sci. Jour., vol. 6, p. 110, 1916. videre (2217, 2232); Stokes Ilill (2220); Thompson Creek near the flume, 2 miles northwest of Betridere (2221); Champion (Wildeat) Draw, three-fourths mile south of Belvidere (2222); Champion (Wildcat) Draw, right (east) branch, in "Lanphier shale," hali a mile south of Belvidere (2224, 2225, 2231); in shale in a draw 1 mile southwest of Betridere (2225); left bank of middle branch of Champion (Wildeat) Draw (2229); shales in draws north of Belvidere (2230); first draw west of Champion (Wildeat) Draw (2233).

\section{Sapindopsis magnifolia Fontaine.}

Plite LV, figure 5; Plate LVI, Plate LVII, figure 2; Plate LIX, figure 3 .

Sapindopsis magnifolia Fontaine, U. S. Geol. Survey IOn. 15, p. 297, pl. 151, figs. 2, 3; pl. 152, figs. 2. 3; pl. 153, fig. 2; pl. 154, figs. 1, 5; pl. 155, fig. 6, 1890; in Ward, U. S. Geol. Survey Mon. 48, pp. 481, 482, 528, 1906.

Berry, U. S. Nat. IIus. Proc., vol. 38, p. 642, 1910; Maryland Geol. Survey, Lower Cretaceous, p. 471, pl. $86 ;$ pl. 87, fig. 1; pl. 88, 1911.

Araha dubia Fontaine, U. S. Geol. Survey Mon. 15, p. 314, pl. 157. figs. 1, $7,1890$.

Sapindopsis obtusidolia Fontaine, idem, p. 301, pl. 156, fig. 13 ; pl. 159, figs. 3-6.

Ficophyllum eucalyptoides Fontaine, idem, p. 294, pl. 164, figs. 1, 2; in Ward, U. S. Geol. Survey Mon. 48, p. $489,1906$.

Sapindopsis tenuinervis Fontaine, U. S. Geol. Survey Mon. 15, p. 301,pl. 153, fig. 1. 1890; in Ward, IT. S. Geol. Survey Mon. 48, pp. 489, 528, 1906.

Rhus uddeni Lesquereux. [Y. S. Geol. Survey Mon. 17 (Flora of the Dakota group), 1) 154, pl. 57, fig. 2, 1892.

Lnowlton, in Ilill, Am. Jour. Sci., 3d ser., vol. 50, p. 213,1895 .

Leares commonly odd-pinnate, although a few eren-pinnate forms occur, of considerable size but somewhat variable. Leaflets three pairs, comparaticely large, lanceolate, tapering almost equally toward apex and base, the base inequilateral except in terminal leaflets, pointed, often lacking apical portions, length increasing proximad, averaging about 10 centimeters, longest seen 14 centimeters (estimated), shortest 5 centimcters, width rarying from 1.1 to 3.2 centimeters, inequilateral, as the outer half of the lamina is broader than the inner lialf and is markedly decurrent. This feature is least emphasized in the basal leaves, which may even have a considerable petiole, but becomes increasingly pronounced distad, the terminal leaflets often forming a bilobate or trilobate 
whole with the outer margins broally decurrent and joining the lamina of the leaflet next below at the point of junction of its inner margin with the rachis. Certain specimens show all the leaflets petiolate, a feature largely emphasized in a specimen from Stump Neck, Md., figured by me in 1911, showing three terminal leaflets with petioles 3 to 4 centimeters in length.

The leaflets in this species are much more commonly petiolate and lacking in the winged rachis than those in $s$. rariabilis, in this particular dosely resembling the leaflets of the molern Matayba apetala, in which the rachial wings are restigial. Leaf substance thick and leathers; epilermis firm and glossy. Leallets commonly subopposite, often markedly so, forming an acute angle with the rachis. Midribs stout and prominent below. Secondaries slender, seen only on the under surface of the leaflets and even there made out with difliculty, eight to ten pairs, branching from the midrib at a rather wide angle, especially in the central part of the leaf; the angle is more acute basally, curving npwari ultimately to join a short branch of the secondary next above. Tertiaries fine, forming lax subrhombic areolne where visible.

This species is rery common at certain localities in the Patapsco formation of Maryland and Virginia, although at other outcrops of this same formation it has not been detected.

The grounds for the separation of this species from $S$. variabilis are slight, ns both are variable and the larger forms of $S$. variabilis are quite as large as the smaller forms of S. magnifotia. In the Patapsco formation the two species are found in association at all the localities where either oceurs, and the smaller species is usually the more common, as if the larger species represented its ocensional more robust forms. On the other hand, $S$. magnifotia has not been detected in the abundant remains referred to $S$. variabitis found at Oak Creek, Wyo., and there is commonly considerable disparity in sime between the two. There are certain other differences which appear to be constant. These are the thicker, relatiroly longer leallets of S. magnifolia, with less numerous and somewhat more uscending secondaries, which are not connected distad by relatively flat arehos.

The form recorded from the Cheyenne sandstone as Rhus uddeni Lesquereux belongs to this species, and I am eonvined that this is true of Lesquereux's type material recorded from the Dakota sandstone and collected, according to J. A. Idden, "from the west slope of the Smoky llill Buttes near Salemburg post office, Saline County. Kans." "lhere are a number of other species deseribed by Lesquereux in the "Flora of the Dakota group" which, although I do not feel justified in transferring them to Sapiudopsis, are open to more or less suspicion. These are Aralia masoni Lesquereux ${ }^{27}$ collected 10 miles northenst of Delplios, Kans., which might represont the terminal part of a Sepindopsis leaf; Laurus angusta Heer." which is a frugment from Ellsworth Count 5 . Kans., that in both form and venation agrees witls Sapindopsis; Legumiunsitrs Jumenophyllus Lesquereux. ${ }^{36}$ which is somewhat less similar to the known species of Sapindopsis; Sapindus diversifolius Lesquereux, ${ }^{31}$ from Ellsworth County, Kans., which is nlso less similar to the known species of Sapindopsis; and Rhus powrlliana Lesqueroux, ${ }^{32}$ ohtained near Fort Harker, Kans., which differs from Sapindopsis in the subordinate lobing and small leaflets developed $n$ the base of the proximal lateral leaflets, in these feratures resembling $R$ lhus, but which is sulliciently like Sapindopsis to be open to more or less suspicion.

This species hns been found in the Cheyenne sandstone at the black hills near Belvidere (773); Osnge Rock, Belvidere (2217, 2232, 7406); Stokes Hill 100 yards south of National Corral (2219); Stokes Ilill (2220); Thompson Creet near the flume, 2 miles northwest of Belvidere (2221); near Medicine Lodge Creek, 2 miles west of Belvidere (2224); left bank of middle branch of Champion (Wildeat) Draw, half a mile south of Belvidere (2229): shale along right branch of Champion (Wildeat) Draw (2228): and right bank of niddle branch of Champion (Wildeat) Draw (2231).

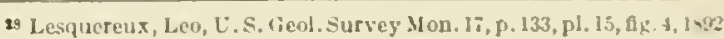

so $1 \mathrm{dem}, \mathrm{p} .93, \mathrm{pl}, 16, \mathrm{flg} .7$.

20 $1 \mathrm{dem}$, p. 1.52, pl. 5.i, figs. $7-9$.

$1 \mathrm{ldem}, \mathrm{p}$. 154, pl. 64, Ag. 15.

2aldem. p. 15.5, pl. ixi, Ags. 4, 5 . 
Sapindopsis brevifolia Fontaine.

Plate IS, figure 1 ; Plate LIX, figure 1.

Sapindopsis brevifolia Fontaine, U. S. Geol. Survey Mon. 15, 1). 300, pl. 153, fig. 4; pl. 155, figs. 1, 7; pl. 163, fig. 3, 1890; in Ward, U. S. Geol. Survey Mon. 48, pp. 481, 482, 528, 1906

Berry, U. S. Nat. Mus. Proc, vol. 38, p. 644; Maryland Geol. Survey, Lower Cretaceous, p. 473, pl. 87, figs. 2-5, 1911

Leaves old-pinnate, the terminal leaflet considerably larger than the lateral leaflets, of which but two pairs are known. These are opposite. Leaflets somewhat crowded so that their margins often overlap, with subacute tips, rarying in length from 2 to 5 centimeters and in width from 0.8 to 1.6 centimeters, averaging about 3 centimeterslong by 1.3 centimeters wide. Inequilateral towarl the base and showing considerable variation in decurrence, eren among the few specimens known; in some the rachis is conspicuously winged; in others the leaflets are all petioled, the whole having the aspect of some member of the Leguminoseae. Milribs stout; seeondaries ascending, camptodrome, seen witl difficulty, as the leaf texture is coriaceous.

This is a poorly marked species of infrequent oceurrence at the same localities where the other species of this genus occur and may simply represent a rariant of $S$. variabilis: in fict, there is no reason for considering it to represent a distinct botanic species, and the name is retained temporarily simply as a geologic convenience, to be eventually dropped entirely.

The Cheyenne sandstone localities are $1 \frac{1}{2}$ miles northwest of Belvirlere (2218), Thompson Creck near the flume, 2 miles northwest of Belvidere (2221); near Medicine Lodge Creek, 2 miles west of Belridere (2224); left bank of micllle branch of Champion (Wilcleat) Draw helf a mile south of Belvidere (2229); Osage Rock, Belvidere (2232).

Sapindopsis belviderensis Berry, n. sp.

Plates TLIX-IIV.

Leaves of rariable size, pinnately compound, ranging in length (in the collected material) from 8 to 19 centimeters and in maximum wid th from 4.5 to 14 centimeters. These leaves are prevailingly odd-pimnate, but a few are even-pinnate. In addition to the odd terminal leaflet generally present there are invariably three pairs of lateral leaflets, which are generally opposite hut sometimes subopposite. These usually decrease regularly in size from the distal to the proximal pair. In some specimens the terminal leaflet is equilateral, but all the other leaflets are inequilateral, of ten markelly so. All except the terminal leaflet are invariably sessile, the latter being separated from the distal laterals in some of the larger leaves by a considerable interval of rachis. Generally, however, the terminal and upper laterals are confluent in the rachial region to form what, if it were broken away from the balance of the leaf, would be considered to represent a palmately trilobate leaf such as is commonly referred to the genus Aralia. The sinuses may be rather broad, narrowly rounded, or pointed. The leaflets rary greatly in size, shape, and marginal characters but agree in being obtuse, generally abruptly and almost truncately mucronate pointed. The leaflets range in form from narrowly spatulate to broadly ovate or obovate. The margins are invariably toothed, but there is great rariation in the amount and degree to which the teeth are dereloped. Proximally the margins are entire for a greater or less distance. Abore this entire portion the teeth, which are remote and rather crenly spaced, may be small and serrate or very prominent and dentate. Tere not all sorts of gradations present one might well doubt that they pertained to the same plants. The accompanying illustrations show these rariations much better than they can be described. The lateral proximal margins of the terminal pair of leaflets, except in a single specimen, are decurrent on the rachis, extending downward to the point of insertion of the next lowel pair of leaflets and often continuous with the distal margins of these. This rachial wing may be broad and triangular, a form which, as the terminal leaflets are the largest, gires the leaf a curious unsymmetrical or artificial appearance. In other specimens the wings are narrow and become reduced to mere marginal hems. In the middle pair of lateral leaflets the proximal margins are only slightly if at all decurrent, and generally they are not decurrent. No decurrence has been observed in the lower lateral leaflets, but they as well as the middle pair have the proximal side of the base fuller than the distal side, the former being generally rounded and the latter 
incurved and sometimes disappearing some distance above the point of insertion. To jullge by the lack of petiolukes and the generally complete character of the material it does not appear that the leaflets were normally shed, and this is also indicated by the concrescence of the terminal loaflets. The leaves are coriaceous and appear to have heen stiff and strict in habit. The rachis is stout and expanded proximad. The midribs are excrssively stout and prominent on the lower surface. 'The seeondaries are rolatively thin, struight, and subparallel. They vary from camptodrome to craspedodrome. In the entire basal part of the leaf and sometimes in the apex they are camptodrome. In many specimens one secondary runs to each marginal tooth, although in other specimens the camptodrome habit is retained and a short branch onters the marginal tooth. All these features are indicated in the accompanying figures. The tertiary renation is usually obsolete, as the matrix is prevalingly coarse. Oceasionally pereurent nervilles are seen. In specimens with broadly winged stripe the renation of the leaf is continued in these wings.

This handsome species is represented by it large amount of material, which is fortunate, as it would be almost impossible to correlate fragmentary material. It is elearly a representative of the genus Saprimdopsis and would well merit the specific name of vriabilis had that not already been used for the type of the genus, which came from the Patapseo formation of Maryland and Virginia.

In the Patapseo formation the genus Saprindopsis may be totally absent from a locality or present in the greatest abundance, and this is equally true of the Cheyenne sundstome of Iansas, indicating possibly a gregarious habit.

Various spereies of existing Sapindacenc show similarities to the present species in form, venation, and variation. All the previously deseribed species of Supindopsis had entire mareins, and no trace of toothed margins has been found in the material from the Athatic Constal Plain. The cxisting genus Jatayba Aublet, with which I originally compared Sapindopsis, has leaves with botl ontire and dentate mareins, and the gencral features of Sapindopsis are shared by other tropical American genera of Sapindacene. The germs Latayba comprises nbout two score existing sporios and is closely roluted to cupanin, nko rachusively American in the existing florn in fuct, all the genera of the tribe C'upminase lomatorrhizae as segredated by hadlkofor are confined to the wimer recrious of the Wrotern Hemisphere.

Oconrence: Lomalitios 2221, 2224, 22209, 22:30, 7406, Medicine Lodge Cresk, in drnw 3 miles above Belvidere (Cherenne sumdstone No. 3 of Hill) ; collected by Wird and Vulughan, October 18, is96 (unnumbered).

Order MALVALES.

\section{Family STERCULIACEAE.}

Genus STERCULIA Linné.

Sterculia towneri (Lesquereux) Berry.

Plate IVII, figure 1; Plate LX: Plate LXI, figure 1.

Aralin townri lesquereux, I. S. Geol. and Geog. Survey Terr. Bull., vol. 1, 1. 394, 1875 [1576]; Ann. Rept. for $1874, \mathrm{p} .349, \mathrm{pl} .4$, fig. ], 1876; (retaceous and Tertiary floras. 1. 62, pl. 6, fig. 4, 18s3; Flora of the 1) kola group. P. 132, pl. 23, figs. 3,$4 ;$, 1. 3], fig. ], 1892 .

Stroulia drakri Cummings, Texas Geol. Survey Third Ann. Rept., 1). 210, fig. 8, 1892.

Knowlton, in IIill, Am. Jour. S..i., th ser., vol. ], 1. $213,1895$.

Sterculia snowii Lesquereux, Flora of the Inkota group, p. 183, , 1. 30, fig. 5 ; pl. 31, figs. 2. 3; 1). 32, figs. J-4, 1892.

Ilollick, U. S. Geol. Survey Mon. 50, P. 94, ]1. 34, fig. $20,190 \%$

Aralia towneri Hollick, New Tork Arad. Sci. Trans, vol. 16, p. 132, pl. 14, figs. 11, 12, 1897 .

lherry, New York liot. Carilen linll., vol. 3, p. 92, 1903.

I have long thought that the Aralia tomeri and stereulia snomiz of lesqueseux represented a single species hut have nover had a chance to test this bedief until l received the present collections from the Cheyenne sumbtone, in which this is one of the most abmondm forms. It shows considerable variation in size but obviously represents a single hotanic species. Lufortunately the name towneriantedates snowiby some lis years, so that thr latter, which is much the hetier known of the two, becomes a synonym.

From the large amount of material now arailabe the spories may be described as follows:

Leares of rariable and often very large sizo, palmataly two to soren lohed. 'Thro lobes are prevailingly conical and acuminate, acea- 
sionally widening somowhat medianly and less acutcly pointed, separated by gencrally open and rounded sinuses extonding about halfway (1) the base. 'The angles that the lobes form with one another and the form of the sinuses vary with the number of lobus, as does also the character of the base, which ranges from trun(ate to decurront. The median lobe is gonerally slightly wider than the others but may be smaller. The normal form is live lobed like the smaller of the two specimens from the (hoyenne sandstone hore figured. The texture is so coriaceous that these leares are well preserred in the scarcely consolidated wind-blown sand of the Cheyenne. The margins are entire. Longtli from \& to 20 centimeters; maximum . width from 6 to 24 centimeters. Petiole stout, usually broken away, 12 centimeters long in a medium-sized leaf figured by Lesquerenx. Midrib stout, channeled, prominent on the under side of the leaf. An equally stout lateral primary diverges from the midrib, usually at its extrene base but necasionally slightly abore. In the fire-lobed forms this primary forks almost immediataly into two subequal branches, which form the midveins of the respective lobes. In specimens having more than fire lobes the additional oncs are subordinate to the basal haterals, their midreins direrge at an acute angle from the milcoins of these laterals, and their separating sinuses are less deep. The secondaries are thin and immersed in the leaf substance and are hargely obsolete in the Cheycmne sandstone specimens; they are numerous, regularly spaced, subparalloled, and camptodrome in the lobes and in culved anastomosing loops in the body of the lamina.

This is an exceedingly well marked species and, like most Sterculias, both ancient and modern, shows the characteristie variability of the genus. It was described originally from matcrial eollected in the Dakota sandstone of Kansas and oceurs in tho Big Turuncari Mountains of $\mathrm{New}$ Mexico in beds referred to the Dakota. It is recorded from the Magothy formation of Massachusetts and New Jersey. In the Cheyenne sandstone of Kansas it occurs at these loculities: Black hills near Belridere (773); Osage Rock, Bolvidere (2217); Stokes
IIil, 100 yards south of the National Corral (2219); Thompson Creek near the flume, 2 miles northwest of Belvidere (2221); near Medicine Lodge? Creek, 2 miles west of Belridere (2224); loft bank of middle branch of Champion (Wildeat) Draw, half a mile south of Belvidere (2229); draws north of Belvidere, in "Lanphior shales" (2230); Osage Rock, in "Stokes sandstone" (2232); Wildeat Draw $(7+0.5)$.

\section{Sterculia mucronata Lesquereux.}

Sterculia mucronata Lesquereux, U. S. Geol. Survey Mon. 17 (Flora of the Dakota group), p. 182, pl. 30, figs. $1-1,189.2$.

Leares coriaceous, prevailingly small, palmately three to fire lobed. Lobes entire, conieal, separated by open rounded sinuses extending a rariable distance, sometimes over halfway to the emneate or truncate base. Petiole long and stout. Primaries three from the top of the petiole, stout and prominent. In the firelobed forms subordinate branches from the lateral primaries furnish these with midveins. Secondaries thin, camptodrone. The tips of the lobes are prominently mueronate, and this feature, which suggested the specific name, is especially obvious in the Cheyenne sandstone specimens, where the mucros are 2 millimeters long and perhaps merit the designation cuspidite rather than mucronate.

The fact that these leaves are prevailingly small suggests that they probably represent small leaves of the associated Sterculia towneri, with which they agree in their main featuresthe mucronate tips of $S$. mucronata being the principal differential characteristic. 'The leaves originally described were obtuined from the Dakota of Ellsworth County, Kans., and the species is known only from that region and the Cheyenne sandstone of southern Liansas, although there is a similar but distinct species, Sterculia minima Berry, ${ }^{33}$ in the Magothy formation of New lersey and Maryland. Two specimens were found in the Cheyenne sandstone near Medicine Lodge River, 2 miles west of Belvidere (2224).

s Berry, E. W. Maryland feol. Survey, Upper Cretaceons, p. $\$ 57$, pl. 4 , figs, $1-3,1916$. 


\section{Order THYMELEALES.}

\section{Family LAURACEAE.}

Genus SASSAFras Linne.

Sassafras mudgii Lesquereux.

Plate I.XI, figure 3.

Sassafras mudqui Lesquereux, Am. Jour. Sci., 2d ser., vol 46, p. 9!, 1s6s; I'. S. Geol. Survey Terr. Rept, vol 6 (rretaceous flora), p. 7s, pl. 14, figs. 3, 4; pl. 30, fig. $T, 1874$.

Ward, I. S, Geol. Surveg Nineteenth Ann. Rept, pt 2, p. 705, pl. 170. figs. 4, 5; pl. 171, fig. 1, 1899.

Berry, Bot. Gaz., vol. 34, p. 137, 1902.

?Kurtz, Mlus. La Plata Rev., vol. 10, p. 53, 1902

According to Newherry, this is morely a variety of his Sassafras cretaceum. but I fail to see any ground for this association cxeept that it resembles somewhat the narrower-Jobed leaves ascribed to that sperios. It is somewhat intermediate betweon those forms and the more typical Sassafras acutilobum but is much more like the modern leaf than either. Losquerenx's figures 3 and 4 of Plate XIV of the "Cretaceous flora" I consider to represent typical forms of this species. In the lengthening of the terminal lobe it approaches the modern Sassafras; and it shows no renation characters which are unlike the modern laf, for although no marginal veins aro discernible, ther might have been pres'nt in the specimen illustrated in Lesquereux's figure 3, as they are in the identical form from the Cheyenne sandstone figured on the accompanying plate, and both specimens approach sasifures in tho relations of their secondary mombers in this region. If it is certain that tho fruit has been found in the same stratn, as lespureux ${ }^{3+}$ asserts, it only serres to substantiate the impression otherwise obtained that they are true Sassafras leavas. The lateral mareins of both the base and the lobes are straighter and more ascending than in the rxisting Sassufras, and the margin shows a tendeney to become wary. Lesquercux's other figured specimen referred to this species difiers in the size and direction of the lateral bobes, in tho subbasal primaries, and in the acute tip; the venation also is somewhat dissimilar, the ascending margins bulge outward, and the base is not decurrent on the petiole, as it is most markedly in the specimens shown in his figures 3 and 4 . It resembles somewhat the forms which Now-

34 Lesquereux, Leo, Flora of the Dakota group, p. 230, 1491 [1*92]. berry rofers to Siassufras acutilobum. Ward's fragmentary leaves from the Black llills are of doubtful identity. 'llie more perfect sperimen that he origrinally reforred to Linedera venustr lesclueroux, which it rescumbles in outline, is a smaller leaf than s. mudyii, with subbasal primaries, considerabla breatlh of blade, and reduced terminal lobe.

Sassufras mudgii was bascel on material eollected from the hills along saline River in central Kansas. Up to the present time it has never been found alsowhere, except for the above-mentioned doubtful record by Ward from the supposert bakota sandstone at Wrans quarry, in Soull Dakota, and a still more doubtful South Americas record by kurt\% that may well be entirely ignored. It may be that the type was from the Mentor formation of central fiansas rather than from the true Dakota sumdstone, as the spercies has never bren found in eollertions from the Upper Cretaceous of the Athantic Coastal Plain, but no outcrops of the Mentor formation are known as far north as Saline River.

The Cheyonno sandstona occurrences are Stokes Hill (22:0) and near Melicine Lodge Creek, 2 miles west of Belvidere (2224).

\section{Order UMBELLALES}

Family ARALIACEAE.

Genus ARALIA Linné.

Aralia ravniana Heer.

Plate 1.V111; Plate LIX, figure 4.

Aralia raviana lleer, Flora fossilis aretica. vol, 6, Aht.2, p. 8., pl. 35, tigs. 1,2, 18.82.

Berry, New lork 1Bot. Ciarden liull., vol. 3, p. 92. pl. 46, fig. 7; pl. 53, fig. 2; pl. 57, lig. 1. 1903: Torrey 13ot. ('lub liull., vol, 31. p. 79. 1904: vol. 37, p. 27, 1910; .laryland Geol. Survey, t pper Cretaceous, p. 876. pl. 82, lig. 4; pl. 83, figs. 1-1, 1916;.

Aralia groenlandien lleer, iclem, pl. 4fi. tig. 17.

Sterculia snowii Hlollick, New York Acad. Sci. Innals. vol. 11. p. 422, pl. 3i, lig. 4. 1s!s

This species was described by Jeer from material collected in the Greenland Upper Cretaceous (Atane beds) and has beon found by me in the Magothy formation of both New Jersey and Maryland. The frugments from Marthas Vincyard, Mass, and Tottenville, N. Y., identitiol as this species by llollick, ${ }^{35}$ are not this species, in my judgment. There is a

2s Ilollick, Arthur, U. S. Geol. Survey $\mathbf{M}$ on. in, p. 92, pl. 3i, figs, 1, 2, 1907. 
great display of Iralia-like forms in the midclle Cretaceous hoth of this country and of Europe, and these forms are especially abumdant in the Dakota sandstone of the West. Comparisons with existing plants are not so satisfactory, although many tropical Araliaceae show suggestive rescmblance. The Moraceae in the genus Artocarpus and its allies also show many similar features.

This most striking species of Aratia, because of its large size, has always been found in a fragmentary eondition. Specimens showing all parts of the leaf hare now been collected both from Maryland and from Kransas, and these conclusirely confirm the restoration of this leaf made by me in 1903. They also confirm the supposition based on the renation of the New Jersey material, that instead of a broally orate median lobe, as Heer supposed, this middle lobe was sublohate by the greater or less derelopment of a lateral lobe on each side, as shown in the accompanying illustrations. The species may be more fully defined in the light of all the inaterial as follows: Leares large, ranging from 16 to 21 centimeters in length and from 19 to 23 centimeters in maximum width, orbicular in general outline, deeply pinnatelobate. Apex of the terminal and lateral lobes bluntly pointed. Base broadly cumeate. Margins entire. Texture subcoriaceous. Lobes usually seren, separated by relatively narrow ultimately. rounded sinuses, comprising an orate medium torminal lobe and two main lateral lobes on each sirle, the lower pair being more or less diriderl. In the Maryland material the auxiliary lobe on the lower side of each main lateral lobe is feebly dereloped. In the Greenland material it is at least half as large as the main lobe, and the separating sinus extends halfway to the base. Petiole stout, its full lengtli unknown. Midrib very stout and prominent, straight. Lateral primaries two on each side, stout and prominent, the lower pair subopposite and supralasilar, the upper pair in some specimens subopposite, more eommonly separated by a wide interval. The lower primary may fork a short distance abore its base, as it does in the Greenland material at an interral of only about 1 centimeter, or this fork may be at least 4 centimeters abore the base, as in the Maryland material, the distance depending on the extent to which the auxiliary lobe is developed. The angle of divergence of the primaries from the midrib is about $40^{\circ}$ but varies from specimen to specimen; the basal pair is in general somewhat more divergent than the upper pair. The secondary and tertiary renation is usually obsolete. Some specimens show "few thin remote secondaries direrging from the primaries at angles of about $45^{\circ}$ and sweeping upward in ascending camptodrome enrves.

The Cheyenne sandstone material is not abundant. It comes from the left bank of the midrle branch of Champion (Wildcat) Draw, half a mile south of Belvidere (2229) and the right bank of the same branch (2231).

\section{Aralia newberryi Berry.}

Aralia newberyi Berry, Torrey Bot. Club Bull., vol. 34, p. 201, pl. 15, fig. 1, 1907; New Jersey Geol. Survey Bull. 3, p. 197, 1911.

Aralia palmata Newberry, Flora of the Amboy clays, $p$. 117,pl.39, figs. 6, 7; pl. 40, fig. 3, 1896 (not Lamarck).

Berry, New lork Bot. Garden Bull., vol. 3, p. 93, pl. 44, 1903; Torrey Bot. Club Bull., vol. 31, p. 79, pl. 4 , fig. 12, 1904 .

Aralia rotundiloba Hollick, New Iork Acad. Sci. Annals, vol. 11, p. 421, pl. 38, fig. 2, 1898.

Aralia polymorpha Newbery, Flora of the Amboy clays, p. 118, pl. 39, figs. 1-5, 1896.

Aralia sp. Hollick, New Fork State Mus. Ann. Rept., vol. 55, p. 155, 1903.

Leaves very rariable in size and outline, palmately three to five lobed. Lobes conical, obtusely rounded. Sinuses open, shallow, rounded. Margins entire, somewhat undulate basally. Petiole long and stout. Midribstout, more or less curved or flexuous. Primaries three to five, from the base, prominent, running to the tips of the lobes. Secondaries very slender, camptodrome. The middle lobe is usually longest and broadest, and the basal lateral lobes may be reduced to subordinate and but slightly marked parts of the main lateral lobes.

The relative development of the apical or basal lobes and the depth of the interrening sinuses greatly alter the appearance of these leares. Some are symmetrical and others decidedly unsymmetrical; some are preeminently three lobed and sublobate and others are five lobed with additional ineipient lobes. The variations are almost exactly comparable with the similar variations in the leaves of the modern Sassafras, Sterculia, and Araliaceae.

There seems to be no basis for maintaining the distinctions between the forms united in 
the foregoing syonymy. The Cherenne sundstoue material is more like the irrocular 1 . polymorplea than the more symmetrical $A$. palmata of Newberry's original material.

The species is common in the Raritan formution of New Jersey and survives in the overlying Magothy formation. In the Cheyenns sandstone it is represented hy three specimens obtained near Medieine Lodge Creek, 2 miles west of Belridere (2224).

\section{Genus ARALIOPSOIDES Berry.}

Araliopsoides cretacea (Newberry) Berry.

Plate I.XI, figure:-

Aratiopsoides cretace (Kewberry) Berry, Maryland Geol Survey, Lpper Cretaceous, p. 8i9, pl. 74, fig. $3 ; \mathrm{pl}$ 8.1, figs. 1, 2; pl. 8.), figs. 1-5; pl. 88, figs. 1-3, 1916 Torrey lint. ('lub l3ull., vol. 35, p. 413, 1911

Sassafras (.Iraliopsis) crinceum Newberry, New York Lyc. Xat. Jist. Annals, vol. 9, p. I4, 1868.

[Lesquereux], [T. s. Geol. and Geog. Survey Terr. lllustrations of ('retaceous and Tertiary plants, pl. 6, figs. 1-1; L. S. Geol. Survey Terr. Rept, vol. 6 (Cretaceous flora), p. 80, pl. 11, figs. 1, 2; pl. 12, fig. 2, 1874; U. S. Geol. Survey Mon. 17, p. 102, 1892.

Newberry, L. S. Geol. Survey Mon. 35, p. 98, pl. 6, figs. 1-4; pl. 7, figs. 1-3; pl. 8, figs. 1, 2, 1898

?Hollick, U. S. Geol. Survey Mon. 50, p. 77, pl. 30 fig. 10. 1906

Penhallow, Roy. Soe. Canada Trans., 3d ser., vol. 1, sec. 4, p. 310,1907

Berry, Torrey liot. Club Bull., vol. 37, p. 22, 1910.

Leaves petiolate, decurrent at base, very smooth above, strongly nerved below, three lobed; ]obes entire and acute The nervation is all strongly defined; the central nerve straight or nearly so; the lateral primary nerve springing from it at an angle of $30^{\circ}$; secondary nerves regularly arched till they approach the margin of the lohes, when they are abruptly curved and run together. From these the tertiary nerves are given off at a right angle, and from these the quaternary nerves spring at a similar angle, together forming a network of which the areoles are subquadrate.-Newherry, 1868.

Newberry includes under Sassafras cretacen the rarious forms described by Lesquerem as S. mudyii, S. subintegrifolium, S. integrifnlium, S. obtusum, S. cretaceum dentutum, S. cretacenum obtusum, S. acutilobum, ('issites harkiamus, and C. salisburiaefolius. Although this list shows the undoubted composite nature of S. cretaceum, it also shows that the extremes of leaf form above mentioned are so closcly conncted with the more typical leaf by a series of intermediate forms that the problem of where one species shall end and another begin is an extremely diffieult one to solve.
I consider the leaf figured by Newberry on Plate VI. figure 1, of "later extinct floras" (Mon. 35) to be the typicul form of this species, thus agreeing with Vewberry's original alescription and with his later opinion expressed in 1895 . This type bent's considerable resemblance to some modern siassafiras leaves. A slight widening of the terminal lobe of some of these in the loasal region would give a leaf strikingly like Aralinpsosides crotacra, or were the sinuses of the latter slightly deeper we woukl have the typical nodern leaf. In its basal portion the leaf is like Sassafras, and the indieations point to a similar renation in this region. The first pair of secondaries do not branch to form margins of the sinuses: the left one runs directly to the sinus, howerer, and may possibly hare conformed to the margin and been effaced in the specimen: the right one is stronger and runs almost to the sinus, where it makes a shurp turn upward, continuing until it joins the next secondary. This feature is analogous to those in the nodern leaf, which may indicate the morte of origin of this peculiar character. This leaf seens to form a central figure from which a series of forms grate in sereral directions, culminating in quite lissimilar leares. Lesquereux's Sassafras cretacenm is a more planatoid leaf. with more acute tips, a tendency to become dentate. and the primaries inserted nearer the base. Closely allied to 5 . cretaceum is his Sassufras 1Aralinpsis) mirabile, which serres as a connecting link with his Platanus recurvata. From the Sassafras cretacemom of Lesquereux it is hut a step to such a leal as the one shown on Phate VIII, figure 2. of "Later extinct floras" and to the trilobed forms referred to Cissites harlevinums, and these in turn grate into the more cissoid forms of this species, such as those shown on l'late 1l, figure 3, of Lesquercux's " ('relaceous florn." The primaries are basal and of not much greater ealiber than the regularly suececling straight secomblaries. It is but a step from this leaf to Cissits heerit, on the one hand, with its palmately five-pointed blade, and to such forms as ('issites acuminatus (PI. V, fig. 4, "Cretaceots and Tertiary floris"), on the other; which in tum. by the elimination of the decreasing dentats points, gives us the leaf shown on Plate $V$, figure 3, "Cretaceous and "lertiary floras." In the second serics of 
leaves direrging from the typical Sassafras cretucem, the form shown in Plate VIII, figure 1 , of "Later extinct floras" is remored a slight distance by the shortening of the blade, the thickening of the primaries and secondaries, and the shortening and rounding of the lobes (Sassafras obtusum); while a smaller leaf would be its logicaldescendant: and from these leaves to those referred to the typical Cissites satisburiaefotius is but a step. In the third series of leaves diverging from the typical Sassafras cretaceum the leal has its lobes much produced, narrow, and running to a sharp point, as in the beautiful leaf shown on Plate VII, figure 1, of "Later extinet floras," which, however, is still referred to. Sassafras cretacenm. Isesquereux's Sassafras acutilobum does not differ greatly from the leaf just mentioned except in the direction of the lobes, which is a questionable specific character. From this leaf it is no great jump to those tritobed forms which are referred to Aralia wellingtoniana, the chief difference being in the margin. Thus we have an interrelated series connecting those len ves which seem to show affinity to Sassafras with those which suggest Platanus, on one hand, and with others which suggest Cissites and Aratiu, on the other.

While it may be considered probable that biologically the forms mentioned in the foregoing paragraphs, as well as others not cited, represent the rariations of a single species of Upper Cretaceous tree or at least represent the leares of closely affiliater species, it seems best with reference to systematic and especially stratigraphic paleobotany that most of the differentiations instituter by Lesquereux be perpetuated. Consequently the present series is limited to the typical material as defined and illustrated by the original deseriber.

Falling within these limits are a number of oceurrences in the true Dakota sandstone and the Raritan and Magothy formations of the Atlantic Coastal Phain. The Cheyenne sandstone has furnished four specimens obtained near Medicine Lodge River, 2 miles west of Belvidere (2224), and one specimen from the lelt bank of the middle branch of Champion (Tildeat) Draw, half a mile south of Belvidere (2229).
POSITION UNCERTAIN.

\section{Genus FEISTMANTELIA Ward.}

Feistmantelia oblonga Ward.

Plate XLVII, figures 4, 5 .

Feistmanclia oblongu Ward, U. S. Geol. Survey Nineteenth Ann. Rept., pt. 2, p. 693, pl. 169, fig. 19, 1899.

In not proposing a specific name for the form of this genus found in the Cheyenne sandstone I emphasize the fact that the tern Feistmantelin denotes merely a form of preserration and that the objects to which it is applied lack either stratigraphic or botanic ralue.

This genus and in fact the nominal species Feistmantrlia oblonga were founded by Ward in 1899 for the reception of certain casts of obscure affinities, but evidently of a vegetable nature, from the Fuson formation of eastern Wyoming. To diagnosis was attempted, but an extended discussion was given of somewhat similar forms figured by prerious authors from rarious geologic horizons. The American Cretaceous forms referred to this genus may be characterized as showing a rather close-set series of elliptical, fusiform, or cigar-shaped convex casts of concare carities formed by the rhytidosis of rarious plant tissues. They rary considerably in size, from 0.6 to 2.5 centimeters in length by 0.35 to 1.0 centimeter in wirth, and are arranged in an irregular spiral, the irregularity being perhaps due to compression. They are thus overlapping or alternate in a horizontal direction and more or less linear in a rertical direction.

Somewhat similar remains oceur at widely separated geologic horizons, and comparable objects with the markings inclined to be Ihomboidal in form are not rare in the New Jersey Triassic deposits, where they are, according to Newberry, ${ }^{36}$ the decorticated trunks of some conifer, possibly Palissya. Similar remains are figured by Schauroth ${ }^{37}$ as trunks of Holtzia coburgensis and by Blanckenhorn ${ }^{38}$ as trunks of Joltzia heterophylla.

36 Newberry, J. S., U. S. Geol. Survey Mon. 14, p. 94, pl. 2i, figs. 1, 2, I8พx.

${ }^{37}$ Schauroth, Deutsch. geol, Gesell. Zeitschr., Band 4, p. 539, 1552. See Schenk, August, Palaeontographica, Band II, p. 308, pl. 4t, fig. 2, 1864. 39. Blanckenhorn, Mlax. Palaeontographica, Band 32, p. 135, pl. 22, figs. 15-20, 18si. 
Among the somewhat simitar forms which Ward mentions are remains from kukurbit, in Fuch (Lias), described by Feristmantel as "portions of a stem of a coniforous plant." Next in point of similarity are certain Engtish and German Weatden remains regarded as " parts of Clathraria anomala, some of which are still referred by Seward" to Bucklondia anomala, a later name for the same plant. The latter are undoubtedly medullary casts of cycadophyte trunks, a rass of remuins for which Saporta ${ }^{42}$ proposed the name Cyeadeomyelon, describing one species from the infra-Lias of Ilettange, near Met\% (Moselle). ${ }^{43}$ Remotely similar remains from the Triassic of York County, Pa., are described by Fontaine ${ }^{* t}$ as Cycadeomyelon yorkense, and the forms described by Newherry are referred to it, although Seward ${ }^{\text {B }}$ had shown that remains from abroad identical with these are to be interpreted as medullary casts of Toltzia. Similar remains were more recently discussed by Wills, ${ }^{47}$ who refigures one of the original specimens of Toltzia coburgensis." They are atso practically identical in character, as Potonie ${ }^{49}$ has shown, with casts of the medullary cavities of certain existing Araucarias, notably Araucaria brasitiana. Other remains of this general sort, which, however, seem referable to the Cycadophyta, are Omphalomela scabra Germar, ${ }^{50}$ renamed by Schimper ${ }^{51}$ Chthruria? germari, and C'ycadeoidea stillwelli Ward.52 As Seward has pointed out, Willianson ${ }^{53}$ figured very similar casts of the medullary cavity of Stigmaria, thus emphasizing the wide range in botanic affinity of objects of this kind.

32 Feistmantel Ottokar, Fussil Hora of the Ciondwani system, vol, 2, [it. 1, ]. til, pl. 10, fig. $2,15 \% \mathrm{i}$.

to Stokes and Webb, Geol. Soc. London Trans., 24 ser., vol. I, pl. th, fig. $8 ;$ pl. 47 , figs. $41,4 c, 1 \times 24$. Swe sehent's figure of Clathraria lyclli Mantell, 1'alaeoutographica, Band 19, p. 227, pl. 31), fig. 7, 187 .

4. Seward, A. C., Wealden ftora, pt. 2, p. 123, 1895.

19 saporta, Gaston de, Plantes jurzssigues, torne 2, 1). 331, 1575

4. Idem, p. 333, atlas, [1. 49, fig. 5 .

"Fontaine, W. I., un Ward, L. F., I. S. Geol. Survey 'wentieit Inn. Rept., pt. 2, p. 245, pl. 30, 19Ko.

4) Newberry, J. S., op. cit.

16 Seward, 1. C., Geol. Mag., dee. 3, vol. 7, pp. 218-221), fig. 1, |w:k

47 Wills, L. J., Geol. Assoc. I'roc., vol. 21, pp. 2y2-241, 1910.

18 Idem, pl. 17, fg. 6.

19 Potonie, H., K. preuss. geol. Landesanst. Jahrb., I\$47, P1. 311-3\$1, 1) 12, 12-13a.

w Germar, E. F., Palaeontographiea, Batu 1, p. 3, Isit.

51 Srhimper, W. P., Paléontotogie végétale, tome 3, 1). 554, I×74.

s2 Ward, L. F., U. S. Geol. Survey 'l'wentieth Ann. Rept., pt. 2, p. ti3t, pl. 149, I900.

5s Williamson, Wv. C., A monograph on the morphology and histology ol Stigmaria ficoides, pl. I3, figs. 61, 65, 1'alaeont. Soc.,. I 357 .
Thuning now to the Cretuceous remains to which the genus, if used at all, shouhd he restricted although Ward loas the temerity to remame Foistmuntel's Indian Liassic fossil Fristmentelin insiformis), wr mat note that in addition to the type species from the Fuson formation, Fontane ${ }^{54}$ has deseribed an additional speries from the Patuxent formation at Corkpit looint, Va., which is really indistingruishable from the type species, and Ward ss has mentioned the ocrurrence of similar objects from Kansits at a higher Cretaceous horizon. Still more recontly Iollick and feffrey ${ }^{30}$ have described comparable remains with structure preserved from the upper" liaritan of Kreischerville, Staten Istand, and have demonstrated their coniferous mature, naming their material Pinns sp.! Some of this material is said to have been found in organir connection with wood showing the chancters of Pitoxylon. It is not altogether clear that the Lowrer Cretaceous speries of Feistmantelia are of the sume nature as that deseribed by Hollick and Jefley, althowgh these authors have furnished the presumption that they are all casts of the interstitial carties of the periderm network of the bark, due to dexay, in some conifer. That they should be refered to Pinus, eren for individual specinens, seems unwise, and the genus Feistmantelia is here retained as a convenient form genus for remains of this sort, which may represent various modern conferous genera.

Indistinguishable remains oceur in the Tuscaloosa formation of Alabama, although I did not ronsider then of sufficiont importanece to inchude then in my paper on the Tuscalonsa flora. They are atso present at as recent a horizon ats the upper part of the Black Creek formation in North Carolina. 'These also I dicl not consider of suflicient interest to include in my accomt of that florm, but I am including here a figure of a North Carolina specincen for comparison with one from the Cheyenne sandstone, to show that the latter is without stratigraphic value.

of Fonlaine W. M., in Ward, L. F., L. S. tieot. Survey Mon. 4\$, P. 14, 1.l. $107, \mathrm{tg} .3,190 \%$.

w Ward, L. k., l'. S. (icol. Survey Nineteeuth . Inn. Rept., pt. 2, p. 694, In:y.

so llollick, Arthur, and Jelley, F. f., Now York Bot. Aiarden Mlem., vol. 3, I. 17, pl. 3, tig. 8; pl. 22, fig. 5, 1909 .

o Herry, L. W., I". S. (jeol. Survey P'rol, P'aper 112, 1919. 
The Cherenne material contained in the and stout, about 1 centimeter in length. The present collection comes from Champion (Wildcat) Draw, three-fourths mile south of Belvidere (2222), and hills between Spring Creek and Soldier, 4 miles northeast of Belvidere, where it is cistremely abundant.

Genus CARPOLTHUS ol authors.

Carpolithus belviderensis Berry, n. sp.

Plate XII, figure 4.

This species is hased on a single characteristie specimen, which is entirely distinct from anything previously described. It represents a large pyriform pedunculate pyxidium 1.5 centimeters in length and 13.5 millimeters in maximun diameter. The peduncle is curved pyxidium is pointed proximad, widest and flatly rounded distard. The sides are distinctly futed with twelve or thirteen rounded nodes separated by shallow rounded sinuses. The ribbing may indicate parietal placenta or a loculicidal habit, al though the latter alternative appears to be negatived by the lid.

It is possible that this conspicuous and characteristic fruit may not have been a true pyxidium and shed its seeds by loosening of the lid, as in Eucalyptus, but that it was a capsule like that of Papaver and the small parietal seeds were discharged through openings beneath the so-called lid, which may represent a concrescent stimua. The specimen comes from Stokes Hill, northeast of Belvidere (2220). 
PLATES XLVII-LXI. 


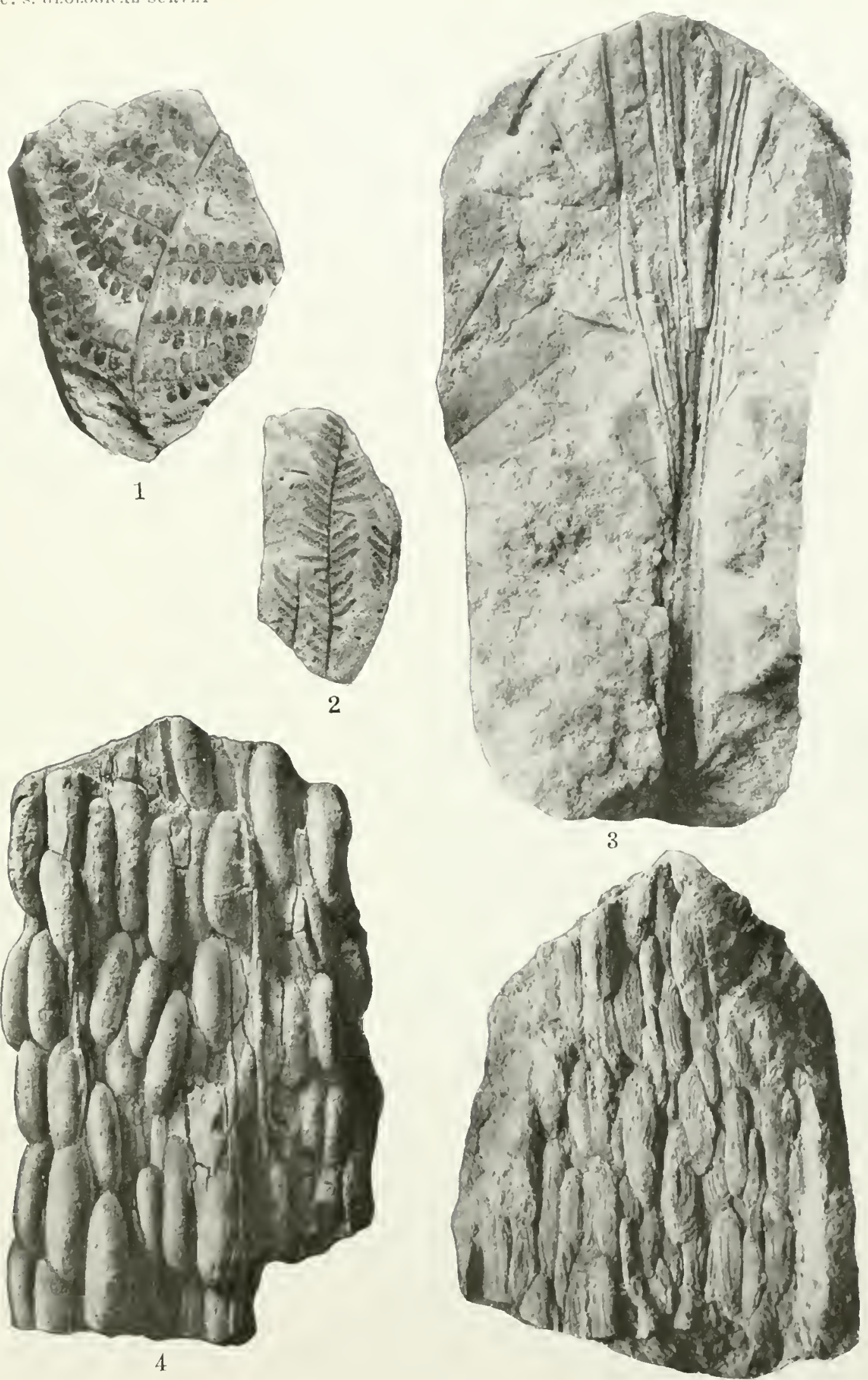

5

FOSSIL PLAVTS FIOU THI: CHFYFNVE STIDSTONE

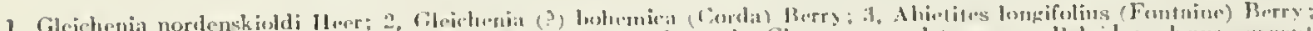

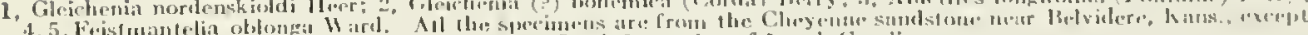

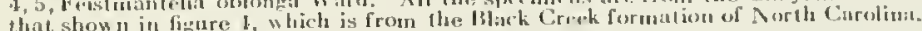




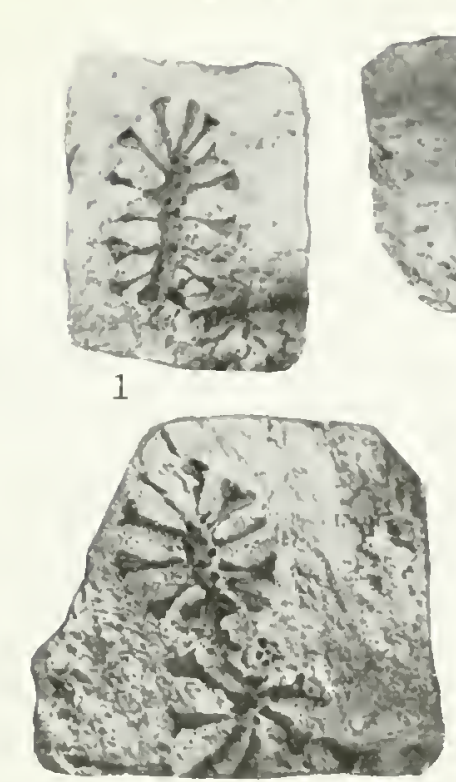

3

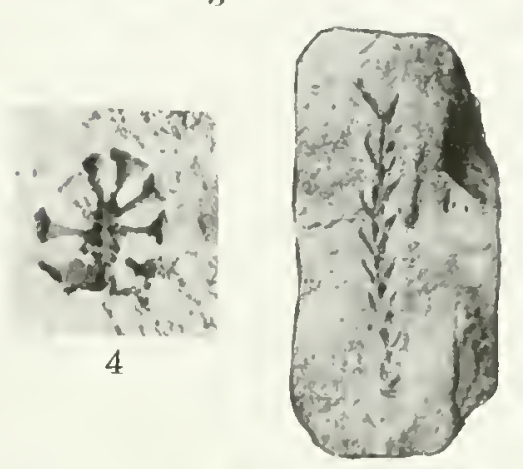

5
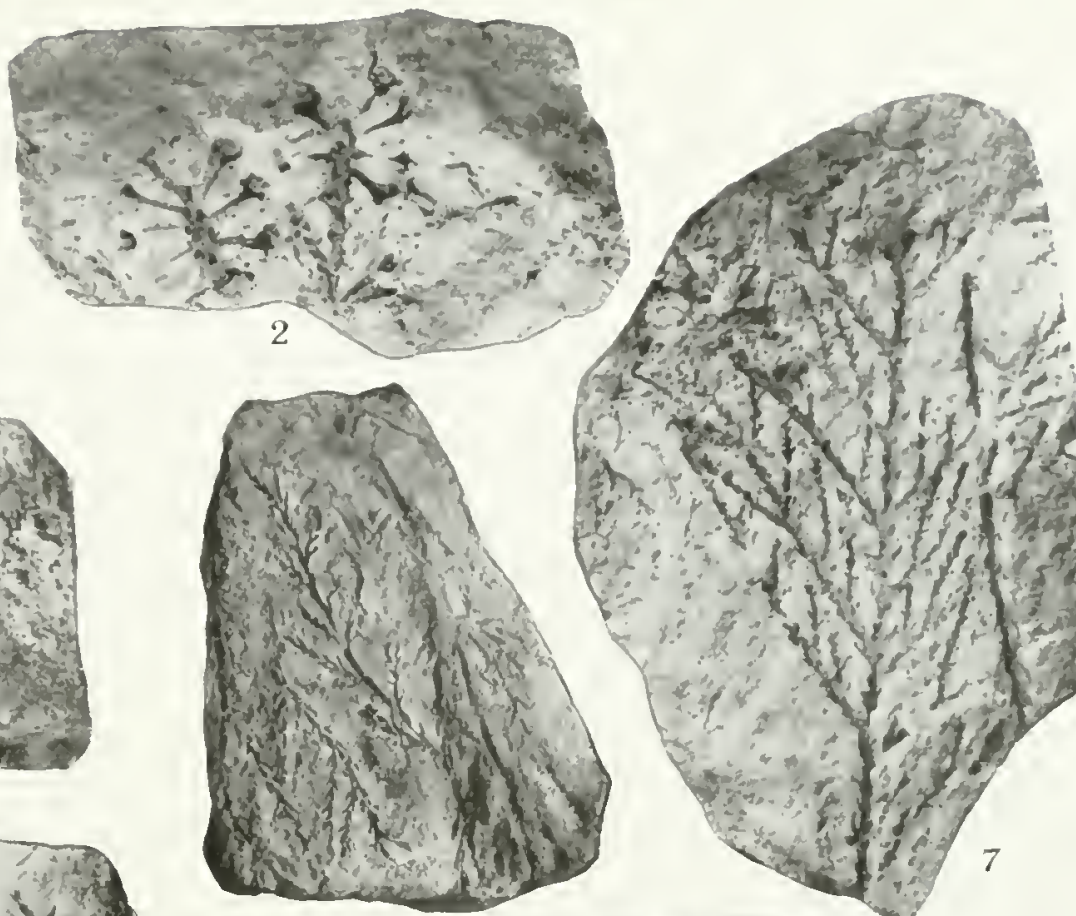

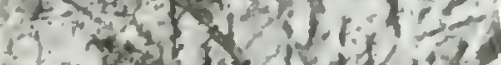

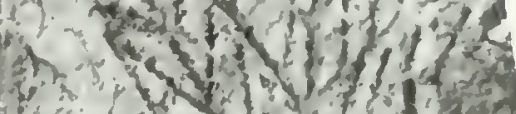

s.

$4: 2$ (n)

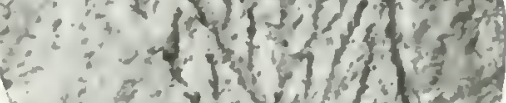

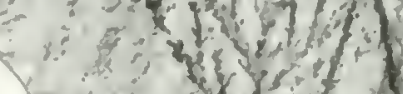

* he ty
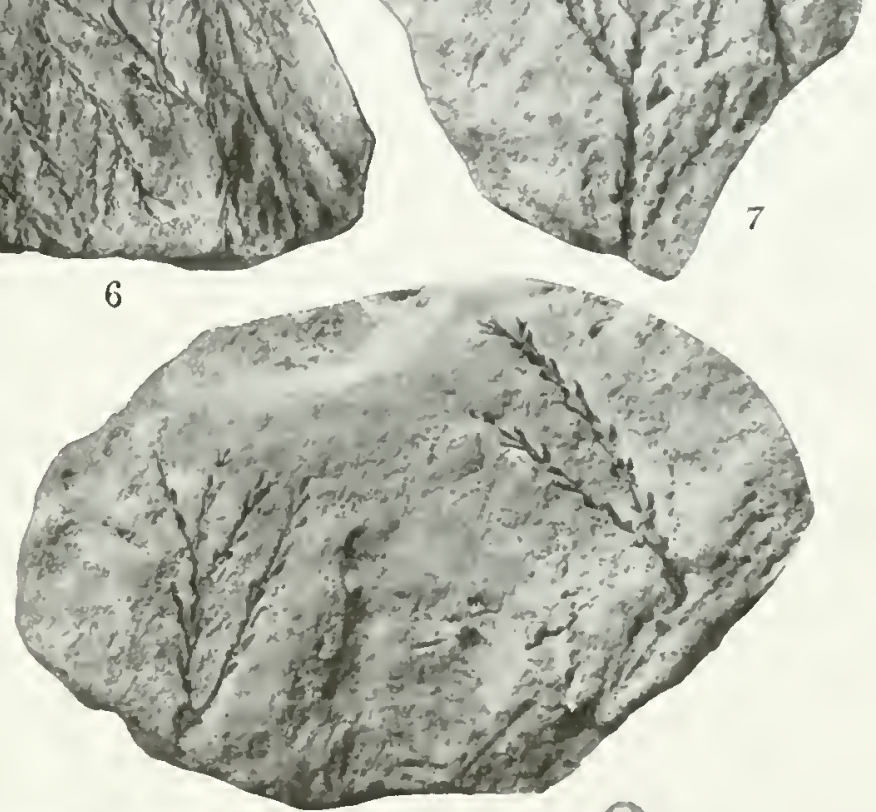

8

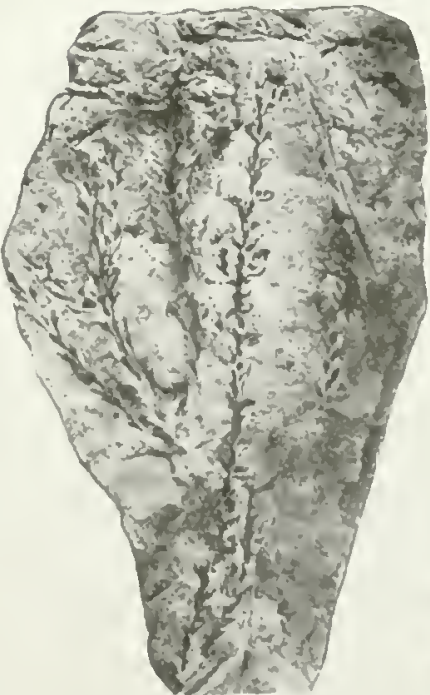

10

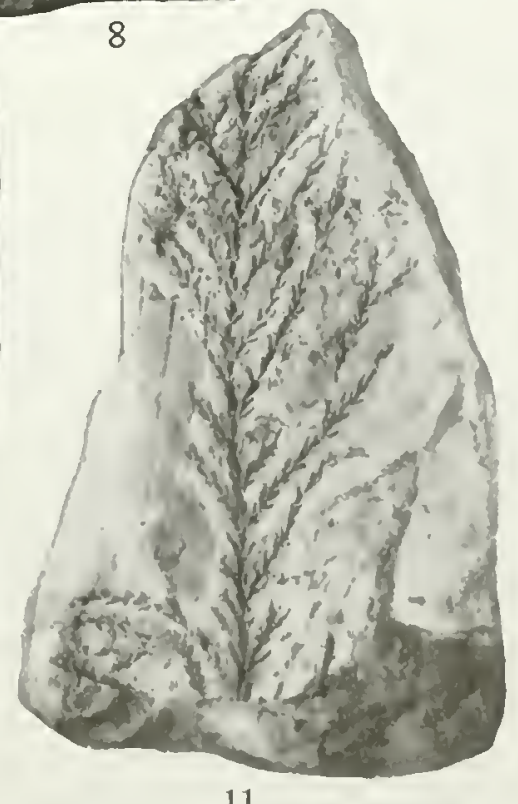



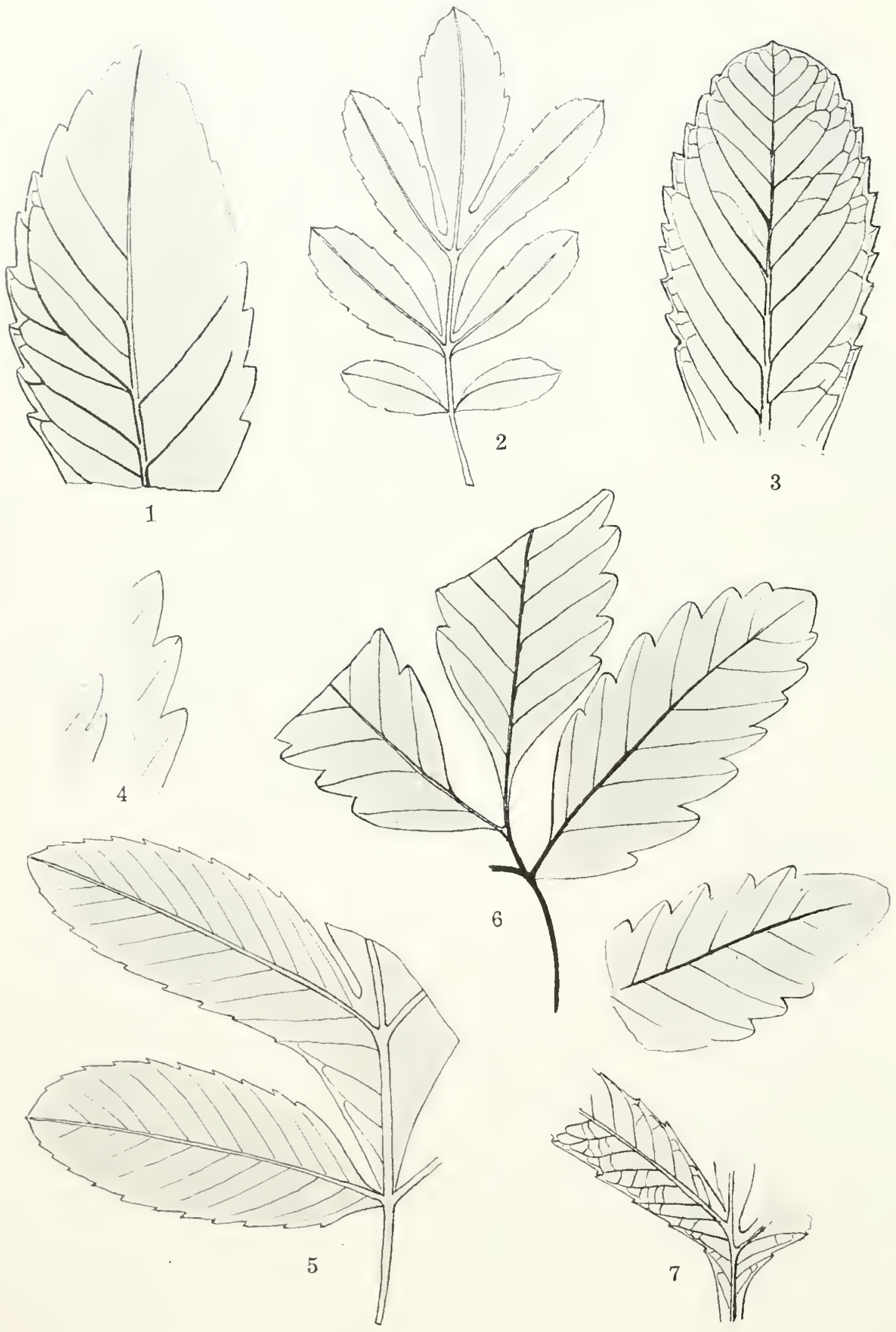

6

AMIVDOPSIS BELVIDEREXSIS BERRY.

From Chayenno sindstone near Pulvilere, Kans. 


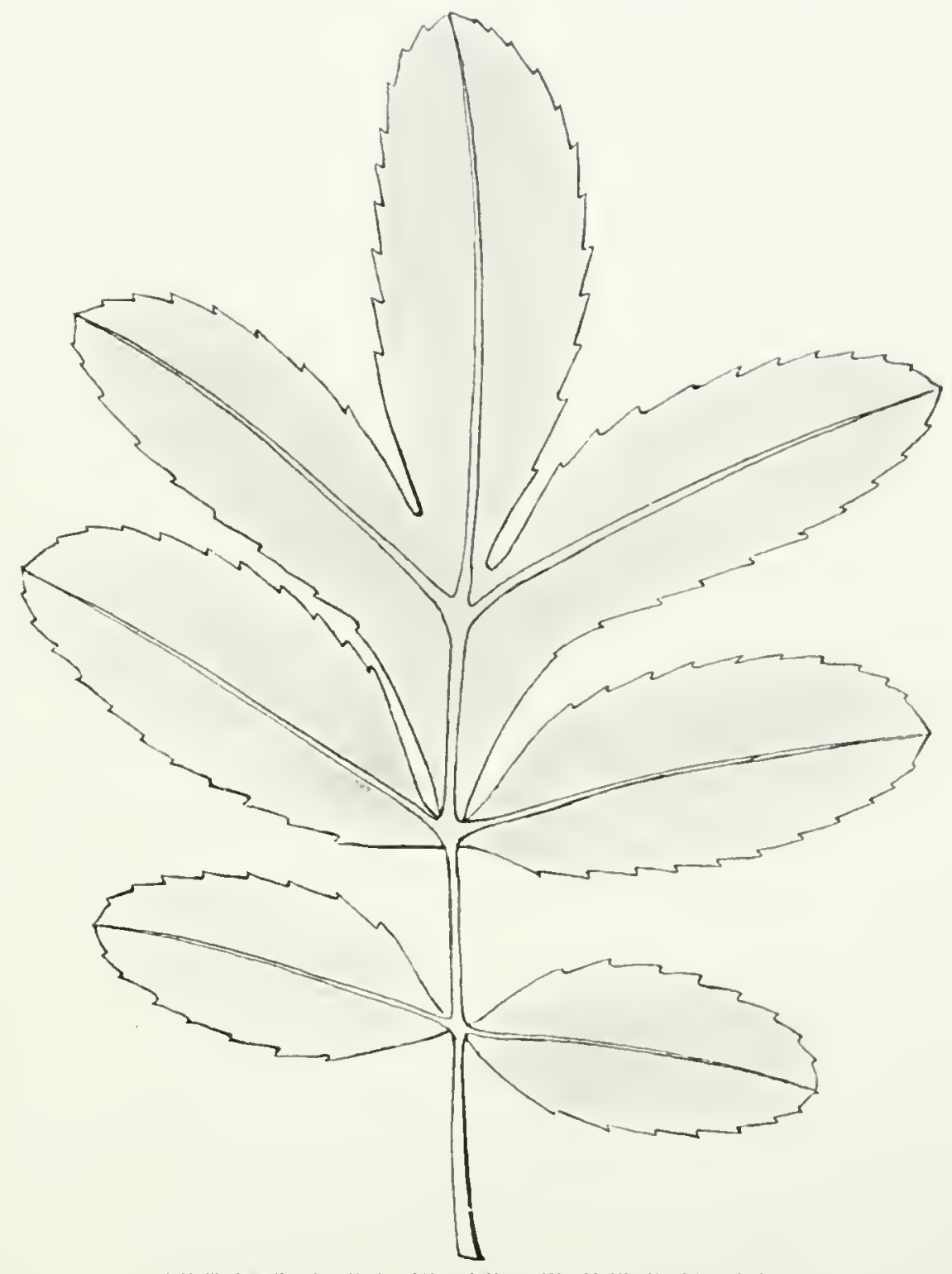

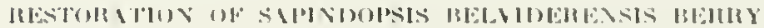




$$
\text { t }
$$




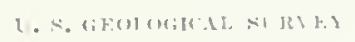

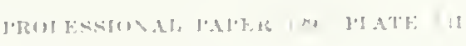

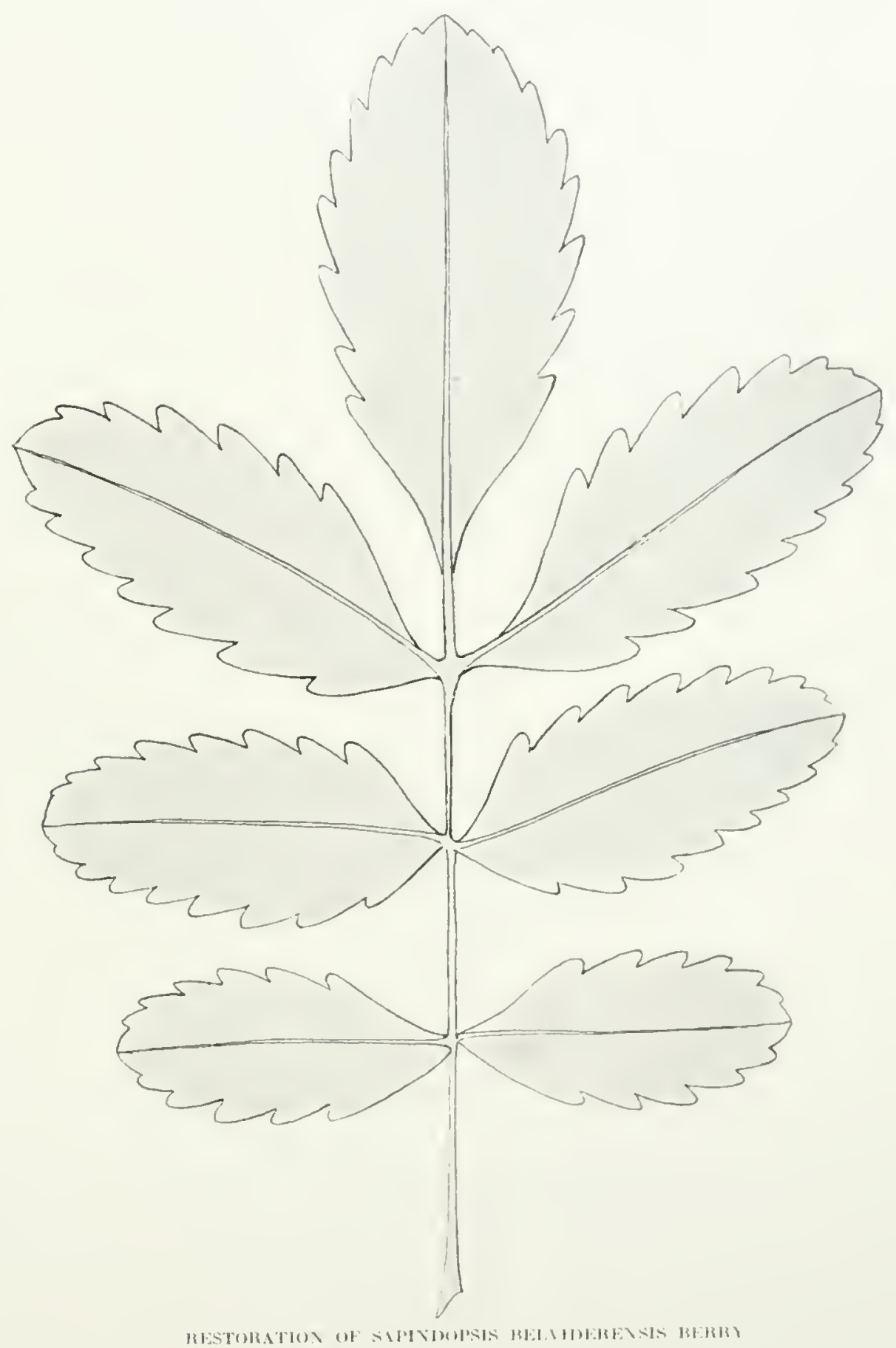




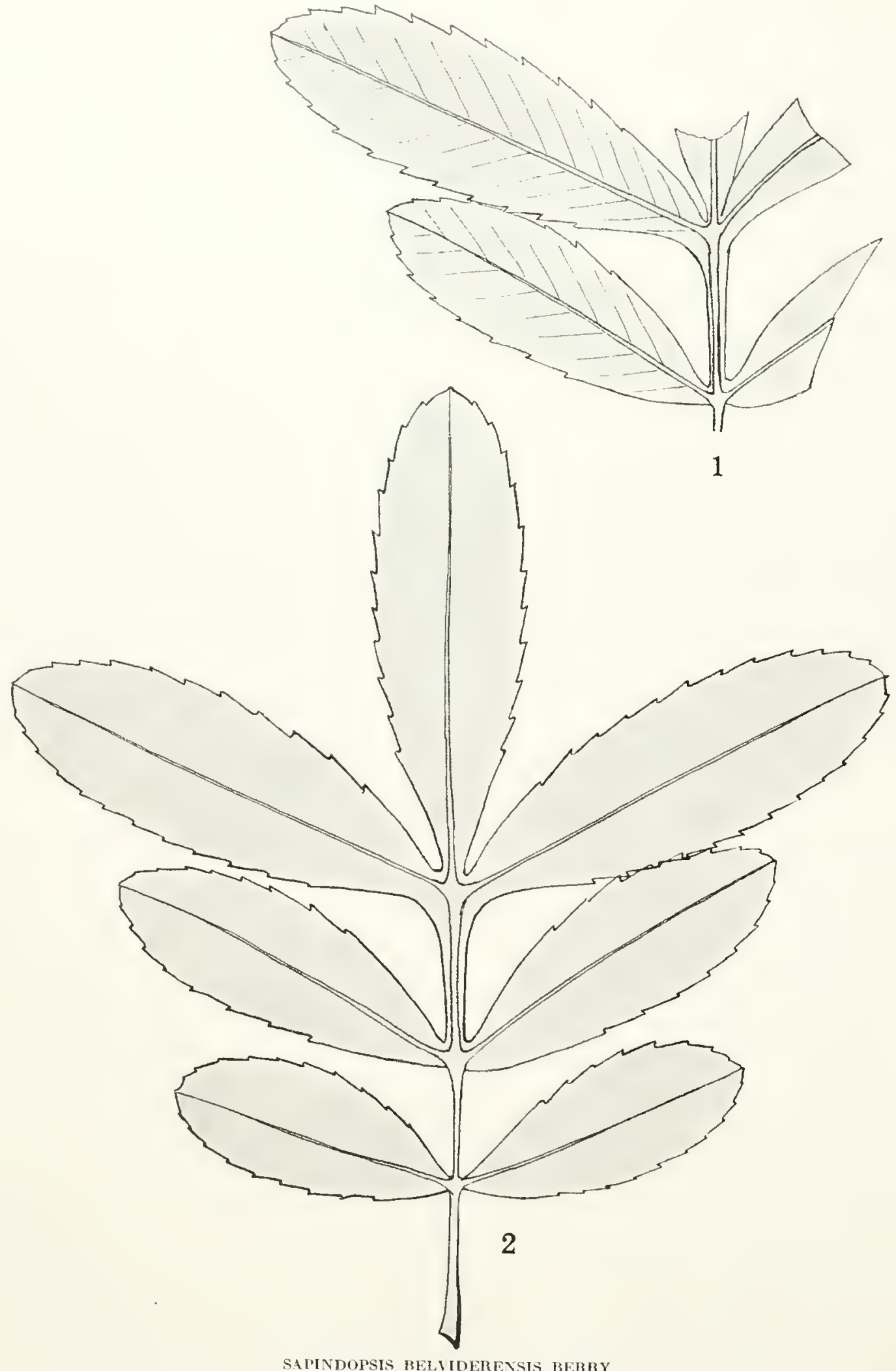

I, Specimen obtained near Pelvitere, Kans, - 2, restoration of sperimen show $n$ in figure I. 


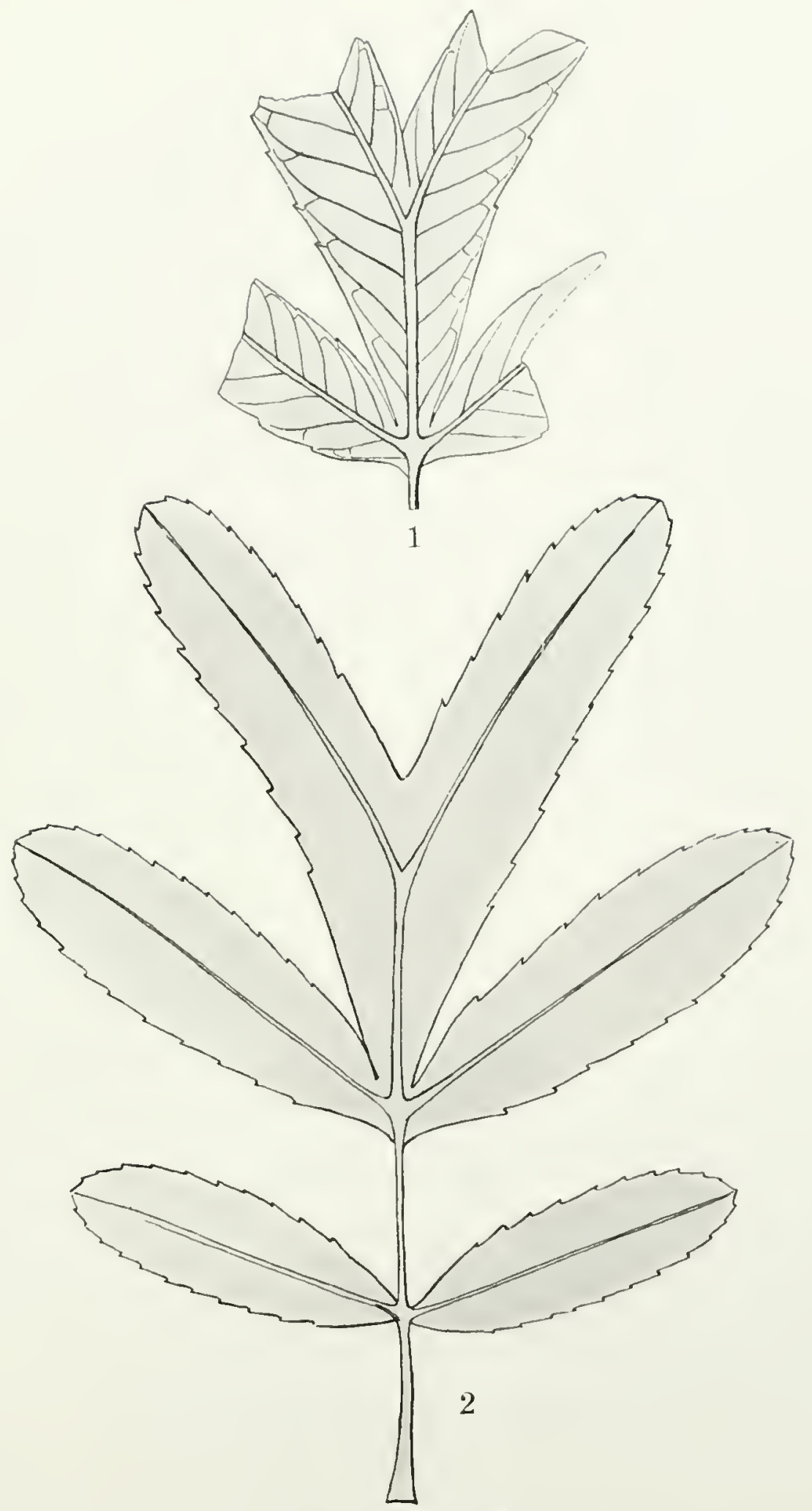

SADINOUISIS BEJUIDERENSIS BERKY.

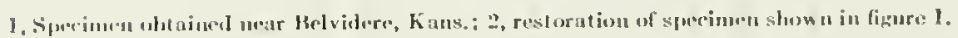



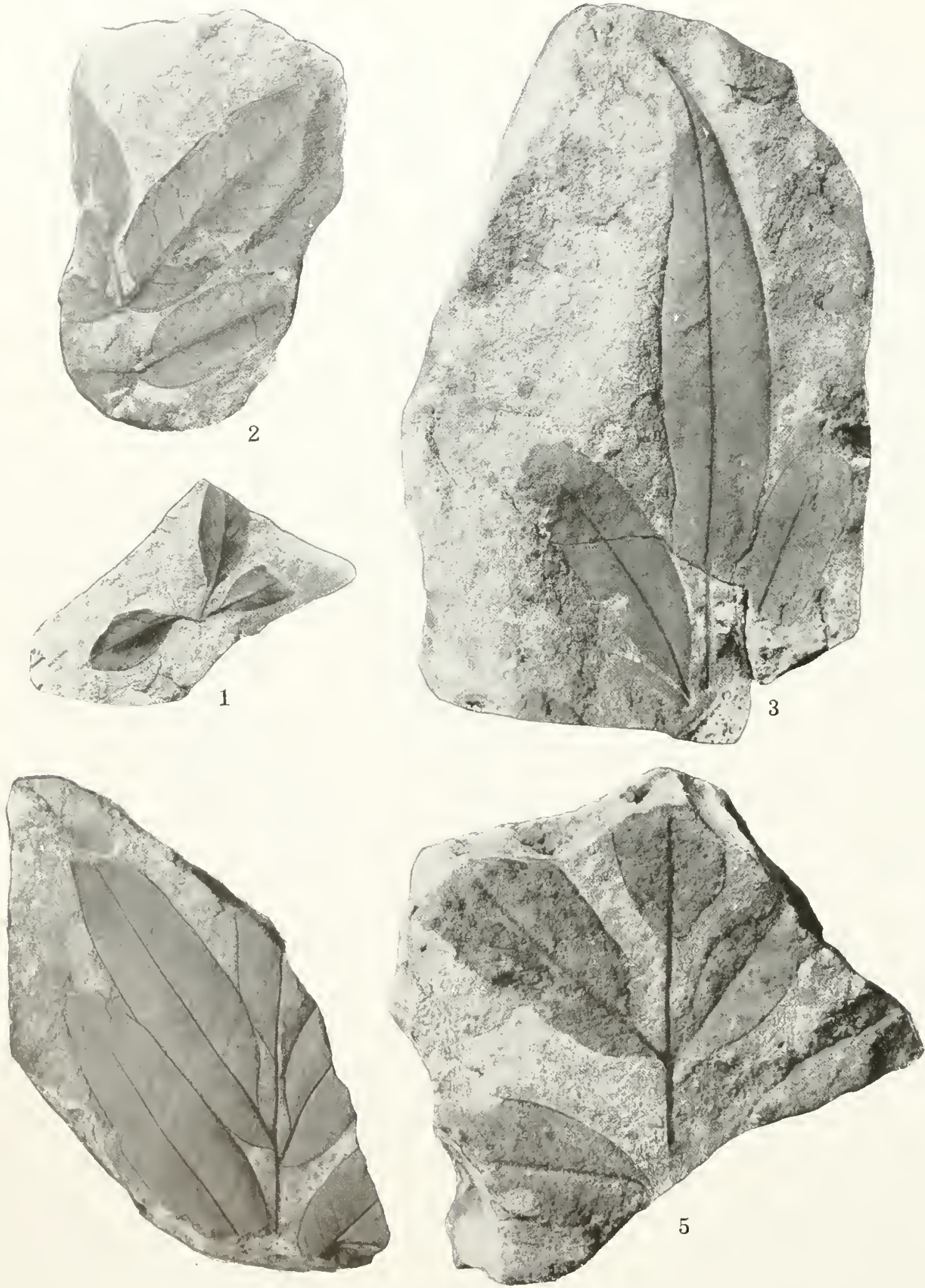

FOSSIL PLANTS FROM THE CHEYENNE SA DOSTONE.

1. Sapintopsis brevifolia Fontainr; 2-1. Sapindopsis viriabilis Fontaine; 5, Sapindopsis magnifolia Fontaine. All collertad near Helridere, $K$ ans. 

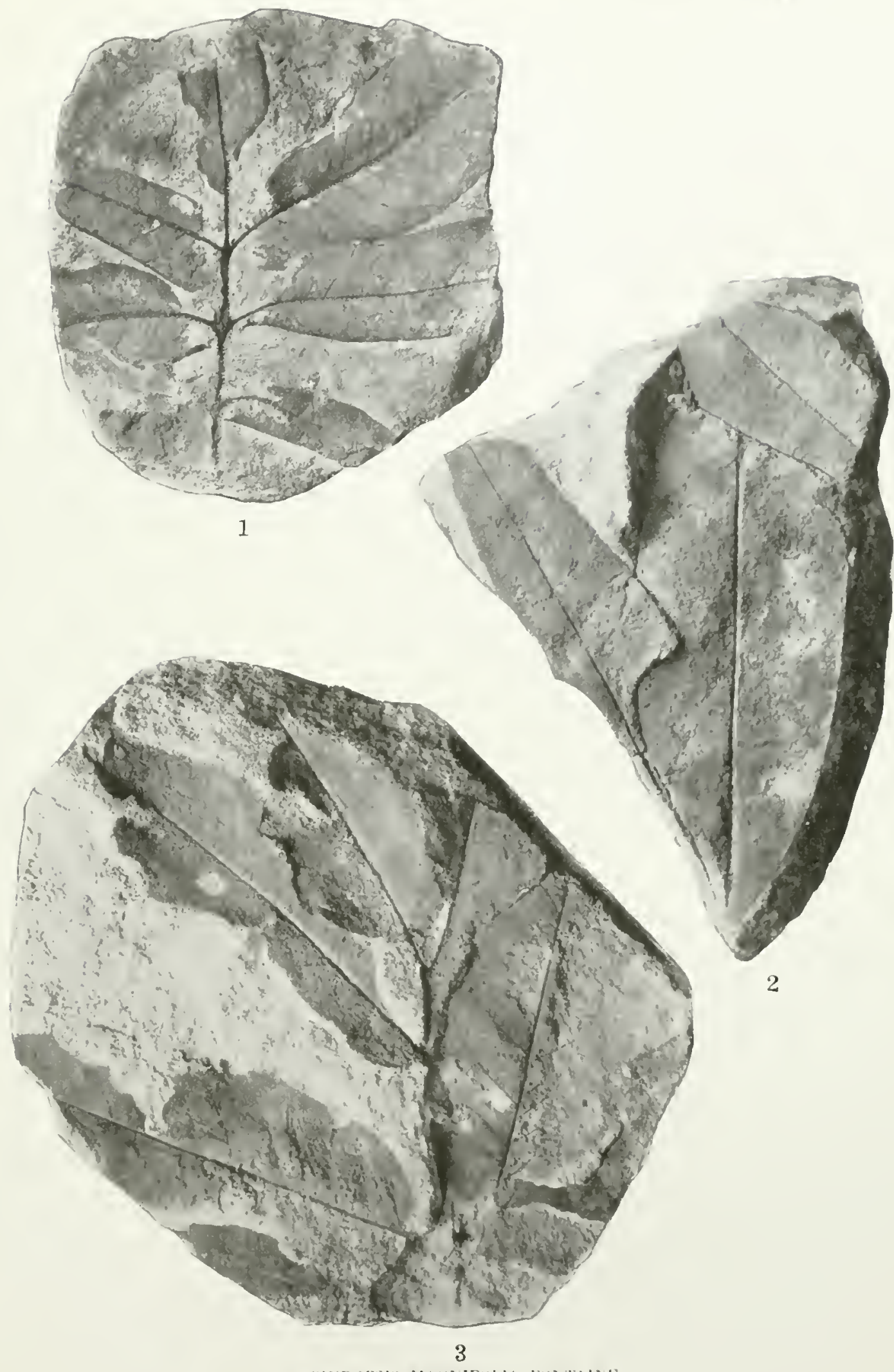

2

MAPNDOPSIS UAGINFUIA FUTAINE.

From Cheyentre samlstome near Bulvidere, Kans 


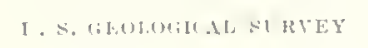

PRORESSTONAL PAPER 129 PIATE LYII

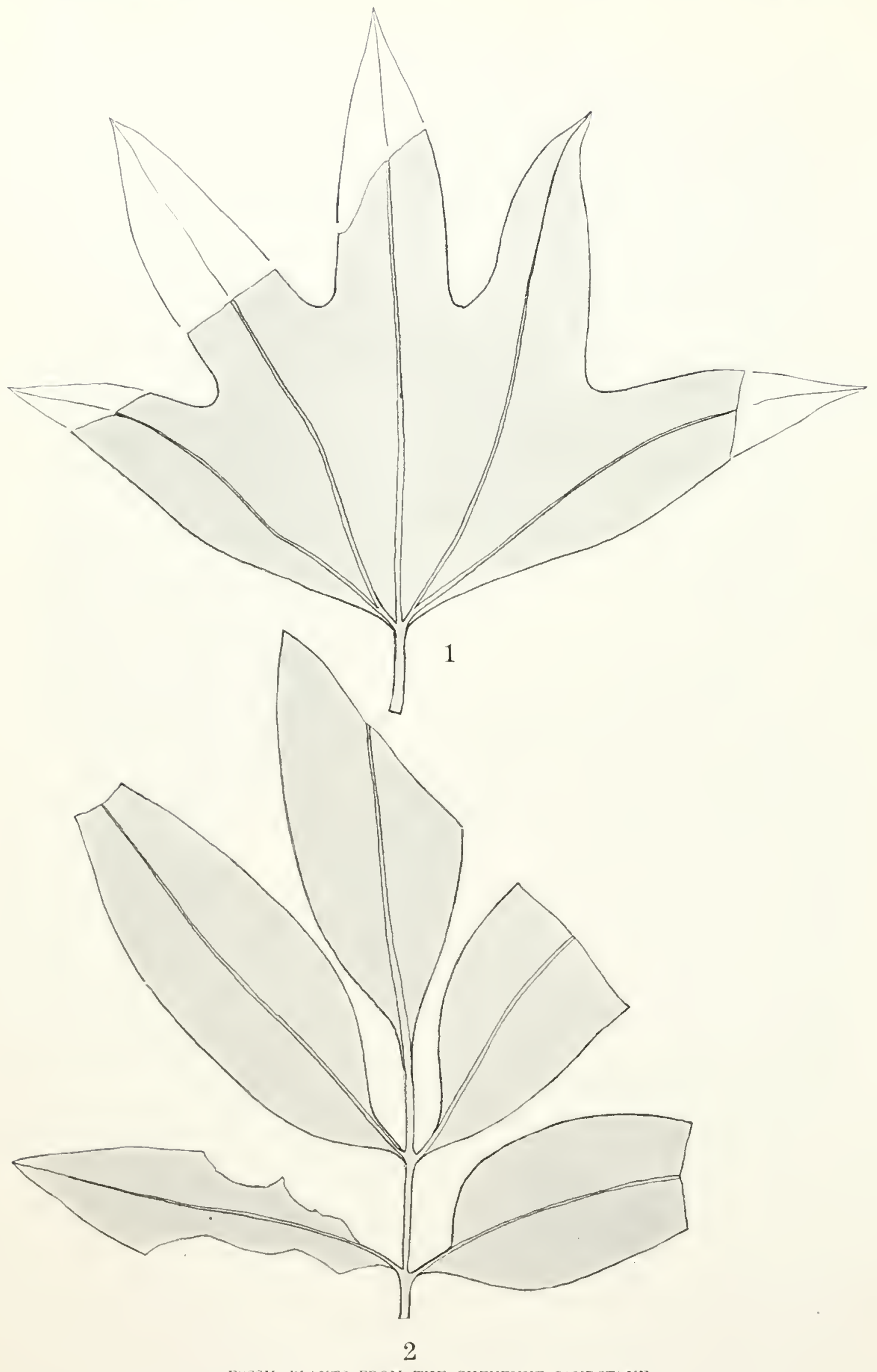

FUSSIL PLAXTS FROM TIE CHEYENTE SANDSTUNE.

1. Sterculia towseri (Lesquereux) Berry; 2, Sappindopsis magnifolii Funtaine. Collected near Belvidere, Kans. 



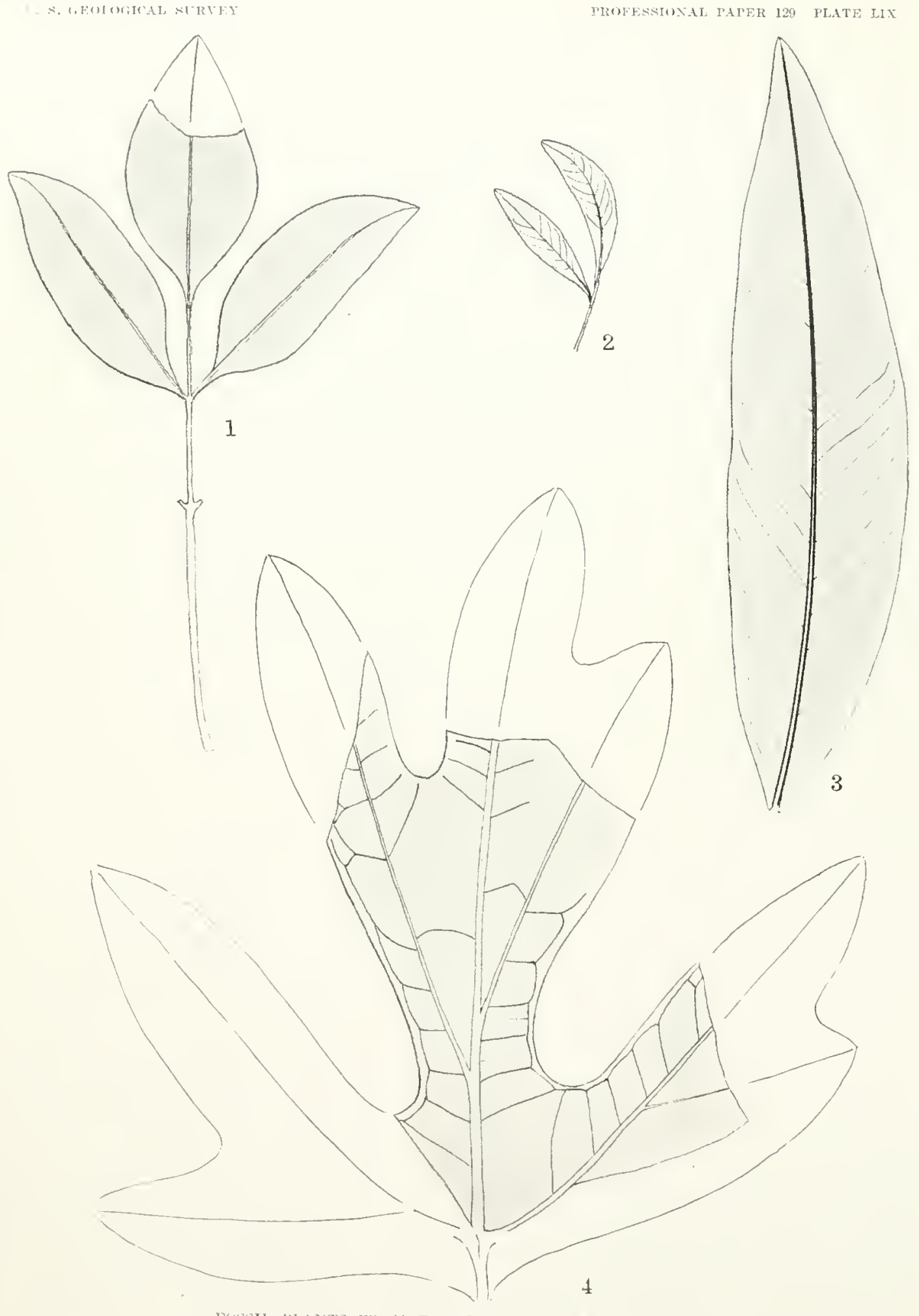

FOSSIL I'LA VTS FHOU THE CIEYEYVI SIVDSTONE.

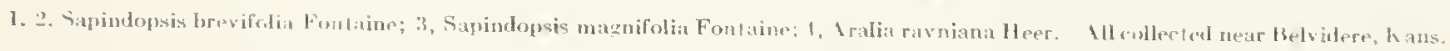




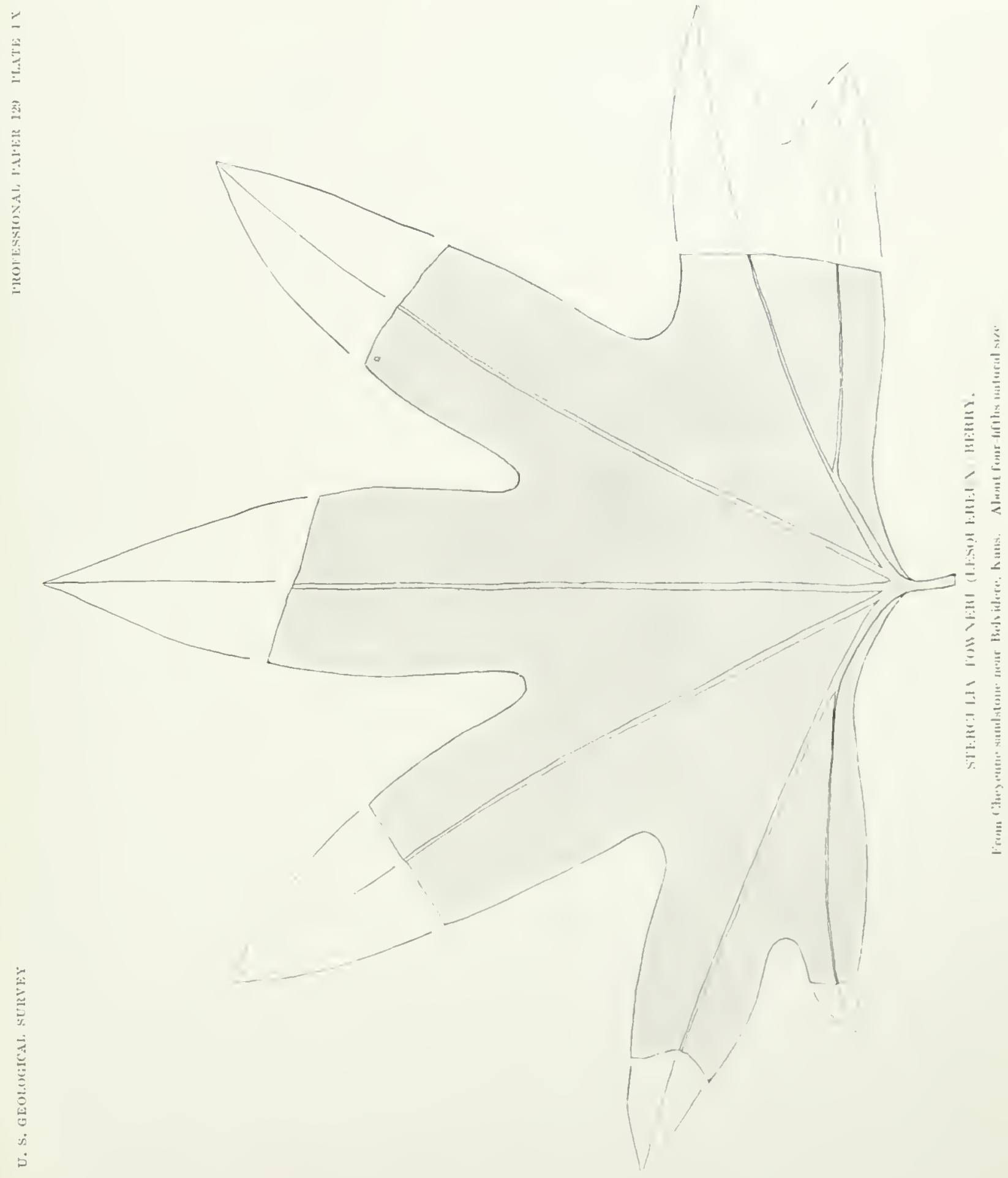



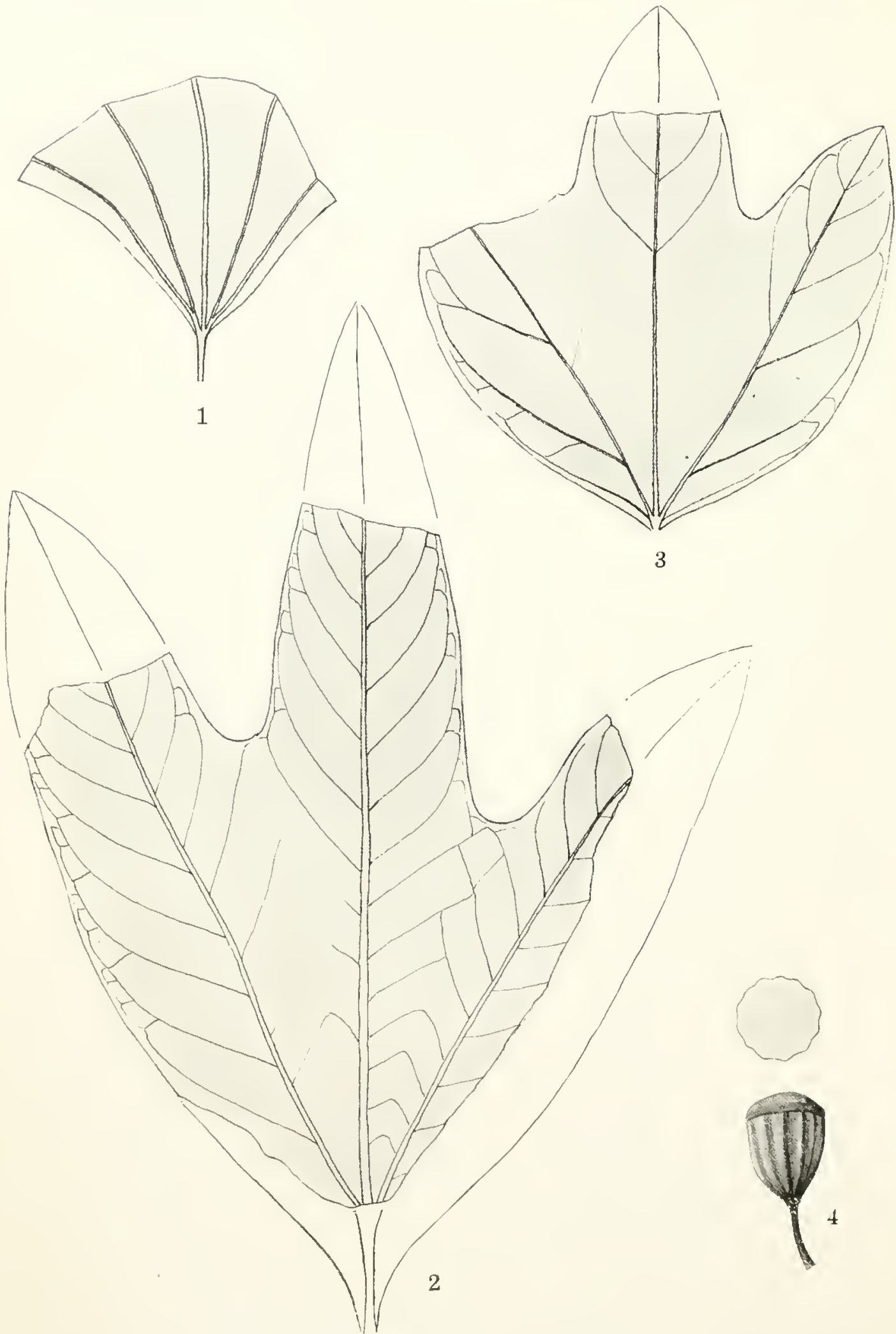

FUSSIL, PLANTS FROU THE CHEYENTE SAVDSTONE

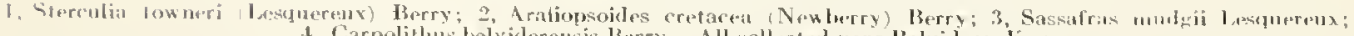

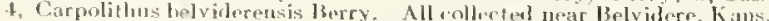




\section{INDEX.}

A.

4 bietites ornestinat Lesquereux, description of .............. 212 longifolius (Fontaine) 13erry, deseription of ............ 211-212 ylate showing .................................. 225

Accuracy in computations, excessive .................... t1

Acknowledgment for aid ............................ 22

A kinetic surface, proposed use of term................... s

Alinement charts, nature of ......................... 42 preparation and use of ................... 44-46, 4\$, 49-50

Allen, E. G., acknowledgment to........................ 22

A ndromeda nonaccnesarene IIollick, description of........... 177-178 norncracsorcar, plate showing. ................... 181 snowii Lesquerenx, description of ..................... 778

. nomalina bilotcrolis Cushman, 12. sp., deseription ol ...... 97-98, 137

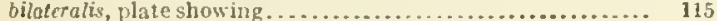
grosser ugosa (Gümbel) H. B. Brady? var., deseription of..... 98

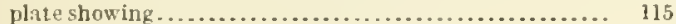
mississippiensis Cushman, n.sp., descriptions of.........94, 137 plate showing................................ 115 icksburgensis Cushman, n. sp., description of............ 137 plate showing .............................. 152

Antelope Hill, Ariz., sandstone emposing. . .............. 188

Antelope Wash, Ariz., section on........................ 70

Aralia newberry Berry, description of . . . . . . . . . . . . . . . . . 220-221 ratriana lieer, description of...................... 219-220 plate showing............................... 225 saportana Lesquereux?, deseription of ............... 177 ucllingtoniana Lesquereux, description of . . . . . . . . . 176-177 plates showing ............................ 1s1

A raliopsaides crefoce (Newherry) Berry, description of . . . . . . 221-222 cretoce a, plate showing ......................... 225

Arizona, northwesters. Sce Mohare County, Ariz.

Arthurs Blu1f, Tex., fossil plants collected at................ 153

A rticulina byramensis Cushman, n. sp., descriptions of.......... 103, 143 byramensis, plate showing.......................... 121

A rundo groeniandico IIeer?, description of.................. 213

A splenium dicksonian um Heer, deseription of.............. 207-20s

Asterigerina subocuto Cushman, n. sp., deseription of.......... 100 subocuta, pláte showing......................... $11 \times$

\section{B.}

Baneroft, llowland, eited. .

Basalt resting on a conglomerate of busalt and other boulders near Toquerville, litah, plate showing.

Bassler, Harvey, Reeside, John B., jr., ald, Stratigraphic sections in southwestern [tah and northwestern Arizona.... 53-77

Beaver Dam Mountains, $[t a h$, section $11 . . \ldots \ldots \ldots \ldots \ldots \ldots \ldots . . \ldots \ldots$

Berding planes, classification of, difficulties in ............. 5

"Bellerophon limestone," fossils collected in................ tifj

Bend series, correlation of well sections with subdivisions of . . . 15-16 difference between shales in ...................... \& 8 distinction between black shale and black limestone in ...... 9 investigation of, difliculty with staining matter........... 2 flint treated separate $y$ in........................ 2 lithologe correlation in, int roduetion to discussion of....... bnature of oil-producing beds in ...................... 20 object and methods of the investigation of ............. $1-5$ position ol oil sands in........................... 15-20 "Smithwick lime". in well borings from ............... 16 summary and conclusions orl...................... 20-22 time required for lithologic work on ................. 20 unit $A$ of well borings from....................... 7 unit $\mathrm{B}$ of well borings from...................... $7-9$ units $C^{\prime}$ and $C^{\prime}$ of $w$ cll borings from ..................... $9-10$ unit $\mathrm{D}$ of well horiugs from......................... 10-11 units $\mathrm{E}, \mathrm{F}$, and $\mathrm{G}$ of well borings from .............. $11-12$ units $U$ aud 1 of well boriugs from. . . . . . . . . . . . . . . . 12-13 unit $\mathrm{J}$ of well borings from.
Bend series, units $K$ and $\mathbf{L}$, of well borings from ........ volcanic origin of material from. white shale in well borings from.

Renzoin tenustum (lesquereux) kinowlt ou, (leseription of. cenustum, plate slowing.

Berry, Edward Whber, fossils determined by

The flora of the Cheyene sandstone of kansas.

The flora of the Woodbine Saul at Arthurs 13lut, Tex

l3ig Horn Mountaius, Ariz., hills of chloritic schist at morth (*) of, plate showing.

Blloculina ornato D'Orbigny, description of ornota, plate showing.. sp.?, description of..... sp.?, plate showing. Bingen sand, relation of flora of, to that of the 14 oodbine sand... 1556-157

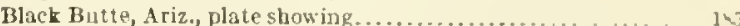
Black Rock Canyon, Ariz., section in..................... 70 Black Rock Spring, Ariz., section near ..................... 75 Blonmington, Utah, sections on Virgin River nea $\ldots \ldots \ldots \ldots \ldots, 75,70,77$ B]oumington dome, [tah, section at . if Bolitina amygdolacformis H. B. Brady, description of.......... gl o mygdalaeformis, plate showing. .................... 100 cookri Cushman, n. \$p., description ol................... 126 plate showing...

frondea Cushman u, sp., description of.................. 12f-127 plate showing... mississippiensis Cushman $\mathrm{n}, \mathrm{s} u$, description of. . . plate showing............................... 109 nutda 11. B. Brady, deseription of.................. gi plate showing.............................. 109 robusta H. B. Brady, deseruptlon of ................ $91-92$ ricksburgensis Cushman, n. Sp., description of.............. 120 plate showing............................. 146 cf. B. punctata D'Orbigny, description of................ 120 Brochyphyllum mocrocar pum formosum Berry, description of... 160-161 macrocar pum formosum, plate showing................ 181

Bulimina ovata D'Orbigny?, description of ................ g. orata, plate showing............................. 110 pupotdes D'orblgny, description of................. 127

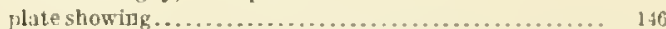

Buliminella contraria (Reuss) Cushman, deseription of........... 128 suberes I1. B. Hrady var. angusto Cushman, n. var., deseription of .............................. $127-128$ plate showing. . . . . . . . . . .

Bullirush, Ariz., section near............................. 70 13yram, Miss., fossils tound near...................... $43-\times 5$ Byram calcareous marl, deposition of.........................

exposures of, at Bytam, Itiss........................ at Woodwards, Miss............................ near Vicksburg, Miss............................ v on Leaf lkiver,. liss.........................

fauna of, descriptions of............................. $\$ 9-105$ oreurrence of............................. $81,4-\$ 5$ relationships of............................. $8 \mathbf{i}-48$

teatures of................................ forminitera found in, at the tjpe station.............. 124-125 C.

Caliche, occurrence of, in the lower Gila reglon, Ariz.......... 190

Carpolith us belvidercusis l\}erry, 11. sp., description of ............ 224

belriderensis, plate showing.......................

sp. 1, description of ............................. 179

sy. 2, description of ................................ two

plate showing................................... 14

sp. 3 , description of ............................. 1 .40

plate showlng................................. 1s!

Cartesian coordinates, disadvantages of.................. th

Casey, T. L., cited .................................. 
Cassidulina crassa D'Orbigny, description of ............... 124 Cuarts for stratigrapluc computations, preparation and use of: $11-$

$45,45-16,49,42,50$

flora of, climate and conditions of growth and embedment.... 203 descriptions of .

early work on.

features of

stratigraphic distribution of .

lossil plants from, plates showing

invertebrates in.

localities in, from which fossils were collected

mechanical analysis of

microscopic examinatien of.

nature of

Chinle formation in Utah, features of..................... 62-63

near springfield, Utah, plate showing.......

Cinder cones north of St. George, Utah, plates showing...........

Cinnamomum membranaceum (Lesquereux) Jlollick, description of ...

newberryi Berry, description of

plate showing.

Cissites for mosus Heer, description of

formosus, plate showing ..........

Cladophlebis dnkotensis (Lesquereux) Berry, deseription of..

Clanton Hills, . 1 riz., limestone composing. .

Clatuline byramensis Cushman, n. sp., deseription of . byramensis, plate showing.

Coalpits Wasb, near Frafton, Utah, panorama along east side of, plate showing

Coconino sandstone in Utah and Arizona, features of .......... $57-5 s$ south of Hurricane, Itah, plate showing ................ 5s

Calutica primordialis IIeer, description of.

Computations, graphic, facilities uceded for................ $39-40$ graphic, publications on numerical, disadvantages of.

Computer, trigonometric, advantages of. trigonometric, construetion of. c. Wre of .............

Cooke, C. Wy the, eited... Orthaulax, a Tertiary guide fossil. The Byram calcareous marl of Mississippi .............. 79-66 Cornophyllum vetustum Newberry, description of ............. 17t Cornuspira incoluens (Reuss) Reuss, descriptions of . . . . . . . . 101, 140 involvens, plate showing.

Court House Rock, Ariz., description of..................... 147

Cragin, F. Wr., fossils determined by...

Cretaceous (?) sandstone in Ltah, features of.

Cretaceous time, sequence of events in.

Cretacenus (?) variegated shalc in ['tah, features of . ................

Cristelloria convergezhs ? Bornemann, description of ............ 130 culurate (Montfort) Parker and Jones, description of. . . . . . . 130 plate showing. rotulato (Lamarck) D'Orbigny, description of...

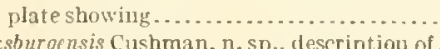
hsburgensis Cushman, n.sp., description of ............ 130-131

plate showing ................................ 113

sp., description of .

Cupressinorylon cheyennense Penhallow, description of . . . . . . 212-213

Cushmar, Joseph 1 ., The foraminifera of the Mint Sprin ; calcare. ous marl menber of the Mfarianna limestone . . . . . . 123-152

The Byram calcarcous marl of Mississippi and its Foraminifera

Cycadeoidea munito Cragin, deseription of ..................... 209

Cycadeospcrmum lineatum Lesquereux, deseription of . ........... 209

$$
\text { D. }
$$

Dakota sandstone, use of term....................... 199-200 Dall, Wilhiam H., cited ...................... 23, 27, 29-30

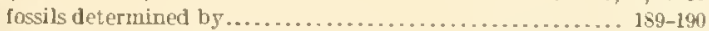
Denison, Tex., fossil plants collected at.................. 153 Depth to a stratum, graphic colnputation of...

Devalquea insignijormis Berty, deseription of.

Diamond Valley, $\mathrm{Ct}$ th, section on notth side of .

Diospyros primecra Heer, description of.

primocva, plate showing. eluracena, plate shotring. bertheloti (D'orhigny) Cushman, deseription of . ........... 135 plate showing.................................... 149 byromensis Cushman, n. sp., description of .............. 96 plate showing............................... 113 orbiculnris (Terquem) Berthelin, description of........... 96 plate showing................................ 113 Distance to a stratum, nethod for computing ................. $46-4$ s Dome Rock Mountains, Ariz., phag of latite in, plate showing... 18.3

\section{E.}

Eagle Tail Mountains, colorat ion of rocks in.................. . 186

Ehrenbergina glabrata Cushman, n. sp., description of........... 93 glnbrata, plate showing ............................ 111

\section{$\mathrm{F}$}

Fcistmantclia oblongo Ward, deseriptien of .................. 222-221 oblonga, plate showing.............................. 225

Ficus da phnogєnoides (Heer) Berry, description of . . . . . . . . . 163-164 dophnogenoides, plate showing. ........................ 1sI glascacana Lesquercux, description of................ 164 Foraminifera. See Cusbman, Joseph 1.

Fossils, from well borings in the Bend series, Texas........... 16 nceurrence of, in the lower Gila region. . . . . . . . . . . . . . . . . 189-190

G.

Gabb, William $M_{.}$, cited ............................... 27,2

Gaudryine triangularis Cushman, description of .............. 127 sp. ?, description of ................................ 127 plate showing............................... 146

Qila, tower, region, Ariz., basal complex of, age of . . . . . . . . . 155-186 basal complex of, classes of rocks in................... 1s3-1St igneous rocks in. ................................... 1st least-metamorphosed sediments in ................. 1.5. metamor phosed schistose rocks in ................ 184-185 nature and distrihution of ...................... 184-1.56 faults older than the Tertiars lava in................... . 192-193 faults younger than the Tertiary lava in................. 19.3

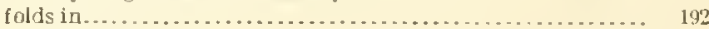
geologic map of . ............................. In pecket. intrusive rocks in . . . . . . . . . . . . . . . . . . . . . . . . $18 \mathrm{f}$ mineral deposits in............................... 197 Paleozoic and Mesozoic events in . . . . . . . . . . . . . . . . . . 194 pre-Cambrian events in. . . . . . . . . . . . . . . . . . . . . . . . 194

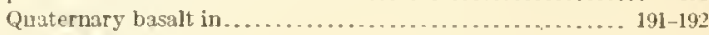
Quaternary faults in............................. 193 Quaternary history of ............................ 19t-197 Quaternary sediments in......................... 190-191 rocks of, variety of .................................... 183 situation and development of ......................... 183 structure of . . . ................................... 192-193 Tertiary history of .............................. 195-196

Tertiary sedimentary formations in, features of............ 186 fossils in . . . . . . . . . . . . . . . . . . . . . . . . . . . $1 \$ 9-190$ nature and distribution of ...................... $18.4-189$

Tertiary lavas in, nature and distrihution of . . . . . . . . . 186-188

Girty, G. 1I., cited................................. 67, 68

fossils determined by.............................66-68 Glauconite, accurrence of, above stratigraphic breaks ...... . 3-1, 20-21 Gleichenial bohemica (Corda) Berry, deseription of . . . . . . . . . . 208-209 bohemica, plate showing ........................... 225 norderskiöldi 11 cer, description of... ................... 20. plate showing................................ 225

Globigerins bulloides D'Orbigny, deserlptions of ............ 95, 13 bulloides, plate showing............................. 113 dutcrei D'orbigny, description of ................... 134 trilobn Reuss, deseription of .......................... 95 Glyptostrobus gracillimus Lesquereux, erroneous identificatlon of 209-210 Goldman, Marcus I., cited . . . . . . . . . . . . .......... 203-204 Lithologic subsurface correlation in the "Bend series" of north-central Texas.......................... 1-2

Gonzales Wells, Ariz., plate showing........................ 181 Gypsina rubra (D'Orbigny) Heron-Allen and Earland, descrtp-

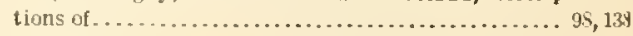

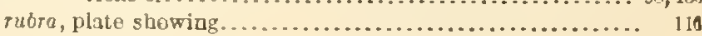




\section{H.}

Hacks Canyon, Arlz., sectlon in ...

Iisrrisluurg dome, L tah, seetion at ...

Jiarristurg gypsiferous member of the Kaihab limestone, fossil: collected from.

Houcrina fragilissima (H. G. Braly) Millett, description of fragilis:ima, plate showing... sp.,? deseription of

Maynes Blutr, Mlss., fossils found in .

lleald, K. C., acknowledgment to..

IIeilpris, A., cited.

IIII, R. T., cited..................

Hurricane, Utah, section sonth of. .

\section{J.}

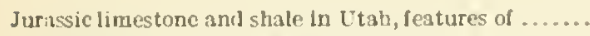

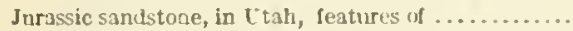

massive, near Springdale, Utah, plate showing... north of St. George, Ltah, plate showing.

\section{K.}

Kaihab limestone, fossils colleeted from.

in Utab and Irizona, features of

sonth of Hurricane, Utah, plate showing.

west of Virgin City, Utah, plate showing ...

Knowlton, F. H., fossils determined by ...

\section{L.}

Lagena heragona (Williamson) Siddall, description of. laeviga ta (Reuss) Terrigi, deseription of...

orbignyana (Seguenza) 1L. B. Brady var. Rintii, C'nshman n. var., deseription of ............................

var. flintii, plate showing .......................... striata (D'Orbigny) Reuss var. substriata Williamson, description of.

rar. sutstriato, plate sbowing ............................

Latite, plug of, in the Dome Rock Mountaius, plate showing. . .

La Verkin, Utah, section near..........................

Laurophyltum minus Newberry, description of. . .

Luurus antecdens Lesqnerenx?, description of ................ plutonia Heer, description of.

Lea! River, Viss., exposure of Brtam marl on.................... lossils found on................................... $\$ 3-45$

Lepiducycline supera (Conrad) H. Douvills, description of ....... 101

Lesquereux, Leo, cited....................... 177, $207,204,212$

Lime, conditions affecting the deposition of................

Liriodendron quercifolium Newberry, description of ............ 166 quercifolium, plate showing........................ 1 1 1

\section{I.}

Maqrolia lacocana Lesquereux, description of speciasa Ileer, description of... plate showing.

Ifalapocnna facilifolia (Leșuereux) Knowlton, description of

Ifresilina crusta Cushman, D. sp., description of.

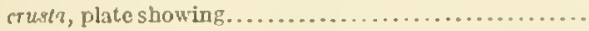

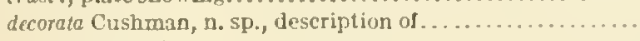

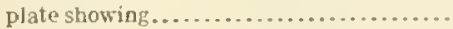

acclusa Cushman, n. sp., deseription of..................

plate showing...................................

var. costulata Cushman, n. var., description of.......... 104

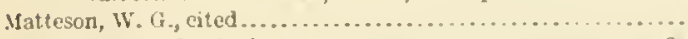

Mizury, Carlatta J., cited............................ 21,31-31

Mertie, J. B., jr., Graphic and mechanical computation of thickDess of stratia and distanee $t u$ a strutum .......... 39-52

"Mlllsap division," use of name......................... 15-16

Minerals, marking of horizons by ....................... 21

Mint Spring marl, feat ures of ............................ $\quad 123$ fossils found in .................................. $42, \times 3-45$ foraminifera found in, at six stitions................ 124-125

Noenkopi formation, features of, is C'tah and Arizona......... $59-62$

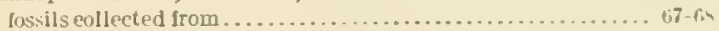
north of Virgin City, C'tah, plate sbowing. west of Virgin City, Ľtah, plate showing....

Nohave County, Ariz., age of the formations in features of.
Mohave County. I riz., fussuls eollecter io. geartal sertion in $34-50$

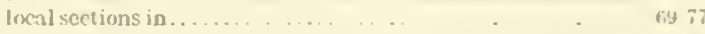
stmatigraphy of . $54-606$ structure of

Myrica emarginala llext, Ife.cription of .

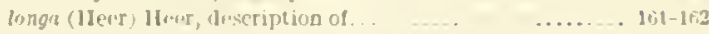
pliste showing. .......................

Myrtonium geinisi (11+er) Jeerry, description of . .......... 175-176

. Volosaria communis borbigny, description of.............. 122

communis plite showing............................. 14t

feliformis (1)()rbigny, (lescription or . . . . ............. 129 plate showing.............................. 147

ohliqua (Linnacus) II. I3. Brady, (Iescription of ......... 129-130 plate showing............................... 197

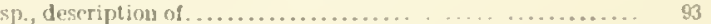
plate showing................................. 110

sp.ฯ, description of ................................. $\quad 93$ plate showing.................................. 110)

sp.?, description of ................................... 130

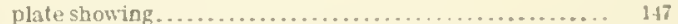

Somionina adiena Cushman, n. sp., rlescription of ............ 139-140 advent, plate showing............................ 149 scapho (Fichtel and MolI) J'arker and Jones, descrjption of . 190, 139 plate showing................ 117 umbilicatula (Montagu) l'arker, Jones, and H. B. Brady, deseription of plate showing.................................. 117 Num mulites sp., deseription of ......................... $100-101$ sp., plate showing.

0 .

Oilsaarls, position of, in the "Bend series," in norih-central Texas. 1-20 orcoda phne alabamensis, Berry description of............. 172-1;3 alabamensis, plate showing........................... in

Orthaulax, correlation tahle of ......................... 25-26 criteria for diseriminating speecies of .................... 24 description of . . ................................... 2i, generic features of ............................... 23-24 occurrence and stratigraphic position of species of .......... 24-36 species of, plates showing.......................... 33-37 aguadillensis Maury, description of...................... 30-31 occurrence and stratigraphic position of ............... 25 plate showing.................................. 3t, 3i

catpa Cooke, n. sp., description of..................... 31 occurrenee and stratigraphic pasition of.............. 25 plate showing................................. 37

gabbi, description of ............................. $23-30$ occurtence and stratigraphic position of .............. 25 plates showing.................................... 35, 36

inornalus, description of............................. 24 occurreace and stratigraphic position of ................. $24-25$ plate showing .

pugnax, description of .................................. 24-29 occurrence ant stratigraphic position of .............. 25 plates showing................................ 34.35

Osago Rock, Dear Belvidlere, Kans., plate showing............ Osborne Wash., Iriz., plate showing..................... is P.

Palcacassia laurine Lesquereux, description of........... dhi- 1 his leurinca, plateshowing.......................... In Palmer, 11. S., methol of, for making stratigraphic computatans. it Patclinn advena Cushmaan, n. sp., description o1.............. 13: adeena, plate showing ................................. 14 Percentage log, description of......................... $1-2$ l'hosphate rock, conditions affecting depositlon of ............. i Platonus latior (Lesquereux) Knowiton, description of ....... 161-1f.5 Plummer, F. B., cited............................... 6,15 Podozamiles lanccolatus (Lindley and Lutton) $k$. Braus, descrip tion of lancealatus, plate showing............................. 1-1 Polynurphina adicue Cushman, n. sp., description of........... 132 ad $\mathrm{Cn}$, plate showing ............................... 14 amygdaltriles (Ret is) Reuss, description of ............... 9.j, 13. plate showing ............................... 112 
Polymnrphina byramensis Cushman, n. sp., description of.... plate showing...

cuspidata H. B. Brady, description of.

plate showing

var. costulata Cushman, n. var.

plate showing

cqualis D'urbignt, description of.

plate showing.

gibbn D'( 'rbigny, description of.

nlite showing

fistulose form, description of.

plate showing

prablema D'Orbigny?, description of.

plate showing.

regina H. B. Brady, Parker, and Jones, description of plate showing

spinosa (D'Orhigny) Egger, deseription of. plate showing

icksburgensis Cushman, n. sp., description of.

plate showing

Populus harkeriona Lesquereux, description of .

Pulinulina adena Cnshmar, 12, sp., description of adrena, plate showing.

byramensis Cushman, n.sp., description of. plate showing.

glabrata Cushman, n. sp., description of........

plate showing...

\section{Q.}

Quingueloculina bicostata D'Orbigny, description of.. bicostata D'Orbigny var., description of, var., plate showing.

contorta $\mathrm{D}^{\prime}$ ()rbigny, description of.

plate showing...

cookei Cushman, n. sp., description of plate showing. .

crassa D'Orbigny?, description of. plate showing. . .

cuvieriana D'Orbigny, description of. plate showing

glabrata Cushman, n. sp., description of. plate showing.

Iamarrkiana D'Orbigny, description of

lustra Cushman, n. sp., description of. plate showing ...

seminulum (Linnaeus) D'Orbigny, deseription of.

tessellat $a$ Cushman, 1 . Sp., description of pliate showing...

ienusta Karrer?, var., description of . plate showing.....

licksburgensis Cushman, n. sp., description of. . plate showing

vulgaris D'Orbigny, description of

plate showing.

sp., description of

plate showing

R.

Red Bluff clay, fossils found in.................... $82,83-85$ Redwall limestone, features of, in Utali and Arizona.

Reeside, John B., jr., and Bassler, 1 larvey, stratigraphic sections in soutbwestern Utah and northwestern Arizona.... 53-77

Reeres, Frank, cited

Rhamey Hill, Tex., lossil plants collected from................ 153

Rhamnus tenax Lesquereux, deseription of.... . . . . . . . . . . . . . 169-170

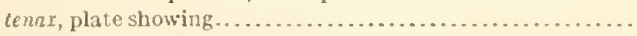

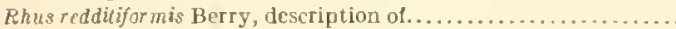

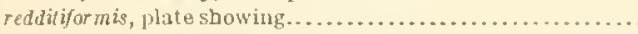

Rhythm in movements of ancient seashores................. 201

Rock Canyon Ariz, section at bead of ................. $70-71$

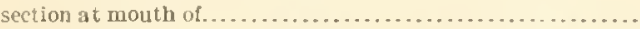

Rock Canyon conglomeratic member of the Moenkopi formation, fossils collected trom...................... 67

Ross, Clyde P., Geology of the lower Gala region, Ariz . . . . . . . . 183-197

Rotalia byramensis Cushman, n. sp., description of........... 99, 138

byramensis plate showing............................ 117
Rotaliu dentata Parker and Jones, description of ..............

plate showing................................ 117

var, parce Cushman, n. var., description of............ 13!

plate showing........................... 152

vickshurgcnsis Cushman, n. sp., description of............. 139

plate showing................................ 152

Roxan a Petroleum Corporation, acknowledgment to........ 22

Rizdd No. 1 well, location of .............................. ${ }_{5-6}^{5}$ $\log$ of, plate showing... . . . . . . . . . . . . . . . . In pocket. section of, correlated with type section................... 15 sections of, thicker than corresponding sections of Sesman weli.............................. $6,7,17$

S.

Saddle Hountain, Ariz., plate showing .................. 18x St. George, I'tah, sections north, east, and south of.......73-75, 76-77 Salix deleta Lesquereux, descrip tion of................. 163 lesquereurii Berry, description of. ..................... 162 Sapindopsis bcliderensis Berry, n. sp., description of . . . . . . 216-217 belvidercnsis, plate showing ........................... 225 brex ifolia Fontaine, description of...................... 216 plate showing ................................... 225 magnifolia Fontaine, description of . . . . . . . . . . . . . . . . . 21+215

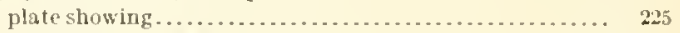
sariabilis Fontaine, description of ..................... 213-214

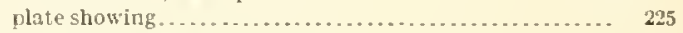
Sopindus mortisoni Heer, description of .................. I6s

Sassafras mudgi Lesquereux, description of .............. 219 mudgii, plate showing ............................... 225

Seaman No. 1 well, location of . ......................... $5-6$ $\log$ of, comparison of synthetic $\log$ with. . . . . . . . . . . . 17 plate showing. . . . . . ...................... In pocket. oil in...................................................... 12 sections of, thcker than corresponding sections of Rudd well . . . . . . . . . . . . .

Sequair condita, Lesquereux, description of ................... 204-211 condua, plate showing ........................... 225 gracillima Newberry, erroneous naming of . . . . . . . . . . . 209-210

Shinarump conglomerate, features of, in Utah and Arizona...... 62 north of Virgin City, Utah, plate showing............ 67

Siphonina advena Cushinan, description of................. 99, 137 adveno, plate showiug............................ 116

Smith's Mesa, ttah, section in.......................... 73

view lorthward toward, plate showing............... 59

Spirillina limbata H. B. Brady var. Bipunclata Cushman, n. var., description of . .............................. 13t-135 limbata var. bipunctato, plate showing................ 149 subdecorata Cushman, 11. sp., description of ............... 95 plate showilig .............................. 113

Spiroloculina antillar $m \mathrm{D}^{\prime}$ (1rbigny, description of ........... 140 antillarum, plate showing............................ 150 byromensis Cushman, 11. sp., description ol. .............. 101 plate showing ............................... 119 grateloupi D'Orbigny, description of.................... 101 plate showing....................................... 119 imprimata Cushman, n. sp., deseription of.......... 101-102, 140 plate showing................................ 119

Sterculia lugubris Lesquereux?, description of............... 171 lugubris, plate showing............................ 1 1 mucronata Lesquereux, description of. ................... 218 towneri (Lesquereux) Berry, description of . ............. 217-219 plate showing....................................... Stratigraphic units, use of term......................... 5 Strombus costatus, plate showing....................... 34 Sulphide, conditions affecting deposition of................. t-5 Supai formation, features of, in Utah and Arizona.......... 57-55 Syuthetic $\log$, description of.......................... 3

T.

Tertiary (?) Sandstone, features of, in Utah.............. 65 Tertiary (?) and Quaternary rocks, features of, iu C'tah and Arizona.............................. 66 Texas, north-central, genera lized $\log$ for ................... 14-20 generalized $\log$ for, plate showing................. 11 pocket.

Testularia aggiutinans D'Orhigny, description of ............ 89 agglutmons, plate showing........................ 108 
Page.

Textularin folium Parker and Jones, description of . plate showing. mississippicnsis, description of...................90, 125-12hi

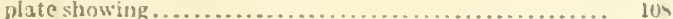

sublinuerii c'ushman, description of ................. \$9-90, 126) plate showing.

tumidulum, description of ..................... $49,12 i$ plate showing............................... 10.

Thickness of strata, graphic computation of, alinement chart for .. 11-1ti

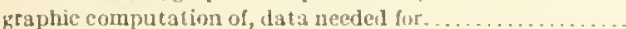
geometric const ruction for. . trigonomelric formula for... graphic representalion of.. mathematical analysis of ...........

Toroweap Canyon, Iriz., section in

Triangle, right, graphic solution of. right, graphic solution of, preyaration and use of chart for graphic solution of, alinement chart for.

Tricalycitcs papyroceus IIollick, deseription of . pepuraceus, plate showing. . . ................

Triloculing oblonga (Montagu) D'Orbigny, description of...... 104-105 oblonga, plate showing........................... 122 peroblonga Cushman, n. sp., description of.............. 1.13 plate showing................................. 151 roturud $D^{\prime}$ Orbigny, description of................... 104 sculpturata Cushman, n. sp., description of.............. 143

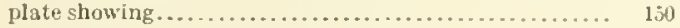
trigonula (Lamarck) D Orbigny, description of ........... 105

Trachodendroides Berry, n. gen., description of ............... 166 rhombsideus (Lesquereux) Berry, description of........... 166-167 plate showing................................ 151

Truncatulina americana Cushman, description of ............. 97 a mericana, plate showing............................... 114 var., description of............................ 136 byramensis Cushman, n. sp., description of............96-97, 136 plate showing.............................. 111 labatula (Walker and Jacob) D'Orbiguy, description of . . 96, 135136 plate showing.................................. 114 pseudoungerizan Cushman n. sp., description of.......... 97, 136 plate showing.................................. 114 vicksburgensis Cushman, n. sp., description of ............ 136-137 plate showing.

\section{U.}

Utah, southmestern. See Washington County, Ttah.

Uvigetina byramensis, Cushman, n. sp., descriptions of...... 9.5, 1:3:-134 byramensis, plate showing............................ 11: pigmen D'Orbign Jescription of . plate showing ............................ 149

l.

l'aginulina legumen (Linnaeus) D'Orbigny rar. elegans (D'Orbigny) Fornasini, description of 93,131
Vaginulina legumen (Linnaeus) D*Orbignv (ve. elegum D'Orbig: Fornasini, plate showiug.

Vaughin, T. W., fossils deternined lov...

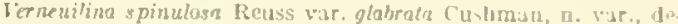
scription of.

rectimargo Cushman, n. sp., descriplion of. plate showing..

Vertebralina adema Cushman, n. sp., description of

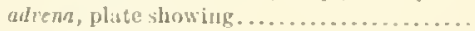

sp., description of. . .

plate showitug.

sp., desription of

Viburnum rabustum Lesquercux, description of ..

robust um, plute showing.

Vicksburg, Mfss., exposures of BrTam mirl hedr.

fossils found near.

Ficksburg heds, tisrly pilleontologic work on.

Virgin City, Utah, sections west of.

Virgin limestone uomber of the Henkopi formition, fossils collected from.

Virgulina sp., description of.

sp., [late showing. .

แ".

Washington County, Ut:ah, age of the formations in.

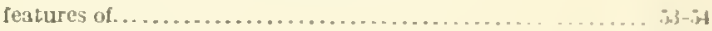

fossils collected in ................................ fin in

general section of ...................................... if

local sections in . . . . . . . . . . . . . . . . .

stratigraphy of .................................... . it

structure of ....................................... 54

Washington dome, $\mathrm{C}$ tah, section in.......................

White, David, acknowledgment to...................... ?2

Widdringtonites reichii (Ettingshausen) Herr, erroneous ifentification of ..............................2tr.4.210

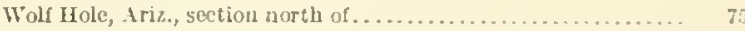

Woodbinc, Tex., fossil plants collceted at............... If\}

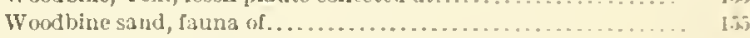

flora of, descriptions of ........................... 15i Iw) distribution of, in other formations............... $15 \%$

early collections of.....................................

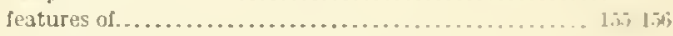

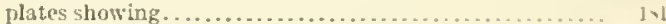

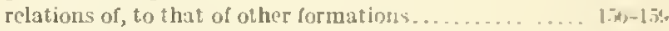

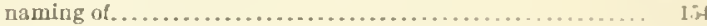

nature and distribution of......................... 1.4 4.1 .55

Woodwards, Miss., exposure of Byram marl at . . . . . . . . . . . .

Woolsey Tank, Ariz., plate showing...................... 14t

bank of wash near, plate showing................ 143

\%.

Ziryphus lamarensis Berry, description of ................ 170

in murensis, ulate showiug.............................

\section{1} 2 $\geq 1$ Ifi 19 (1) 2 (1) 19! 11
$4 !$

क.

(7)

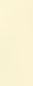

II

63
, 3 

DEPARTMENT OF THE INTERIOR

ALBERT B. Fall, Secretary

UNiTED STATES GEOLOGICAL SURVEY

George Otis Smitu, Director

Professional Paper 129

\section{SHORTER CONTRIBUTIONS TO GENERAL GEOLOGY}

\section{1}

DAVID WHITE, Chief Geologist

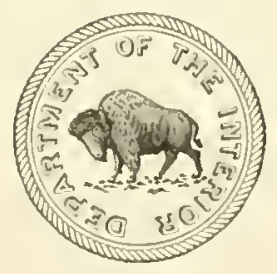

WASIINGTON

GOVEINMENT IIINTING OFFICE 
1

$+$ 


\section{CONTENTS.}

[The letters in parentheses preceding the titles are those used to designate the papers for advance publication.]

(A) Lithologie subsurface correlation in the "liend series" of north-eentral Texas, hy M. 1. fioldman (puhlished

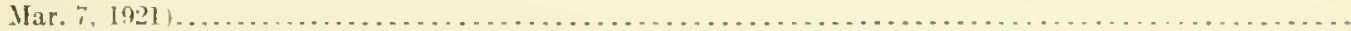

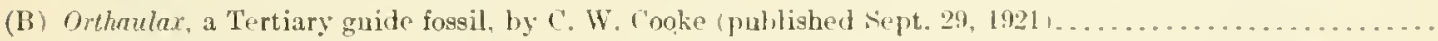

(C) Graphic and mechanieal computation of thickness of strata and distance to a stratum, by . 1. B. Mertie. jr.

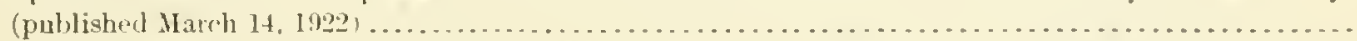

(D) Stratigraphic sections in southwestern I'tah and northwostern Arizona, by . . 13. Reeside, jr., and IIarvey Bassler (published Harch 22, 1922).

(E) The Byram calcareous marl of Mississiphi, by C. W. Cooke (published March 17. 192.2) ............ The Foraminifera of the liyram calcareous marl at lyyam. Miss.. by J. 1. Cushman (published Mlarch 17. (192)

(F) The Foraminifera of the Mint sipring marl member of the Marianna limestone. by J. .1. ("uahnan (puth

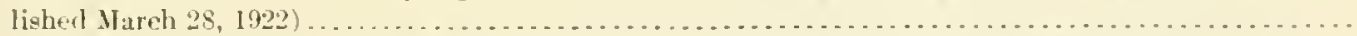

(G) The flora of the Woodbine sand at Irthurs lihuf, Tex., by F. W. Berry (publishıd Mareh 23, 1922) ......

(II) Geology of the Inwer Gila region. Iriz., hy C. P. Ross (published March 29, 19.2) ..............

(I) The tlora of the Cheyenne sandstone of Kansas. by F. 11 . Berry (published April 11, I922) ........ Index. 


\section{ILLUSTRATIONS.}

PLATE 1. Logs of the Seaman and Ruld wells and a generalized log for north-rentral Texas ....... In pocket.

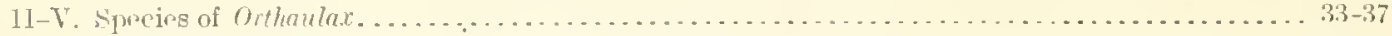

V1. Alinement chart for graphic computation of thicknrss of strata...............

VIl. Alinement chart for graphic computation of de

VJII. Alinement cliart for graphie solution of right triangles. . . . . . . . . . . . . . . . . . . . .

IX. H. Coconino sandstone and Kaihab limestone in I] urricane fault scarp, 6 miles south of Hurricane, Ltah; $B$, Closer view of middle part of scarp shown in A: C. (Tpper part of Kaibal)

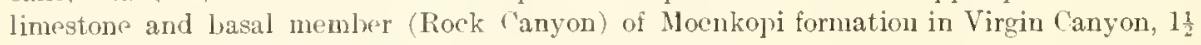

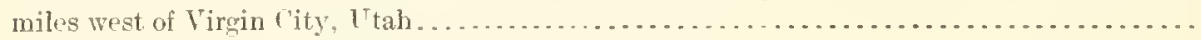

I. A, View northward toward Smith's Iesa from a point just south of Virgin City, Ltah; $B$, Panorama along east side of coal pits Wash near Grafton, Ltah . . . . . . . . . . . . . . . .

II. 1, Chinle formation and overlying massive Jurassic sandstone in Zion Canyon above Springlale, Ttah: $B$, Cross-bedling in white upper part of massive Jurassic sandstone 12 miles

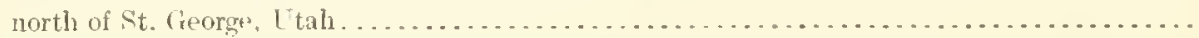

XII. A, Group of cinder cones of late date and associatel lava. Diamond Valley, 12 miles north of st. Feorge. Utah: B. Tearer view of larger cone of group shown in $1 \ldots \ldots \ldots \ldots . . . .$.

XIII. A, Shinarump conglomerate resting on upper Moenkopi shale and sandstone, Smith's Mesa. 3 miles nortl of Virgin ('ity, Utah; $B$. Late basalt flow resting on a conglomerate of hasalt

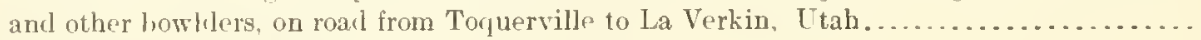

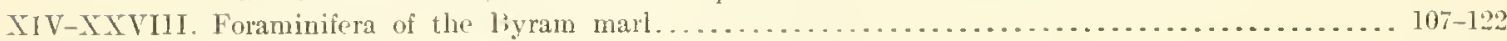

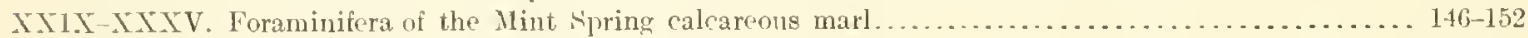

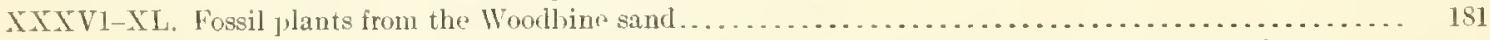

XLI. I, Hills of chloritie schist at the northern end of 13 ig IJorn Moztntains, near Palo Verde mine, Maricopa County, Iriz.: B. Cionzales Wells, Dome Rock Mountains, Yuma County, Ariz..

XLII. A, A plug of latite of Tertiary age in the Dome Rock Mountains, about 4 miles southwest of Quartzsite, Yuma County, Ariz.: B, Blark I3utte, Cactus Plain, near Osljorne's Well, Yuma

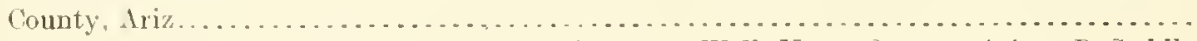

XLIII. A, Osborne Wash, about 2 miles southwest of Osborne's Well, Yuma County, Ariz.; B, Saddle Nountain, Maricopa County, Ariz., looking south...........................

XLIV. A, Bank of wash near Wooksey Tank, Gila Bend Monntains, Maricopa County, Ariz.; B, Woolsey

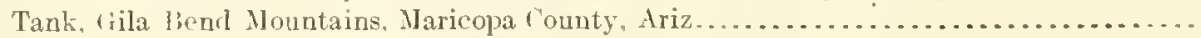

ILV. Reconnaissance geologic niap of the lower Gila region. Ariz..................... In poeket.

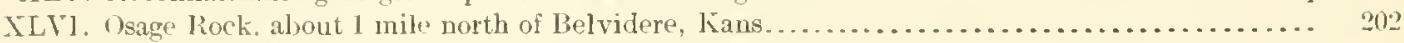

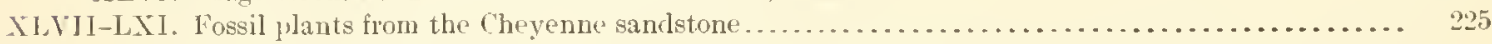

Ficile 1. Outline máj) showing the position of the seaman and Rudd wells, north-central Texas, and their

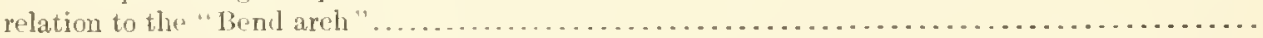

2. Creometric rezresentation of the thickness of a stratum when the lip of the stratum and the relative positions of a point on the upper surface of the stratum and another on the lower surface are given..

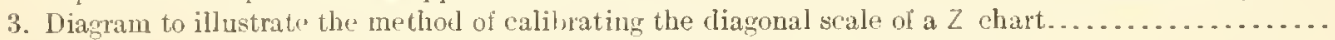

4. Diagram to illustrate the method of fetermining the locus of the curvilinear scale in an alinement chart consisting of two parallel straight-line scales and a curvilinear scale.................

5. Geometric presentation of the distance to a stratum when the dip of the stratum, the position of a loint on the stratum relative to the starting point of measurement, and the lorizontal and vertical directions of the line of measurement are given . . . . . . . . . . . . . . . . . . . . . . . .

6. Right-angled triangle showing the relations of slope distance, horizontal distance, difference of eleva-

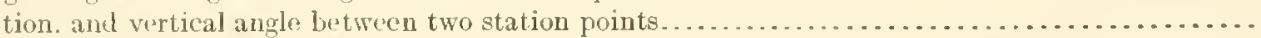

7. Diagram illustrating the combination of three alinement charts for the solution of right-angled

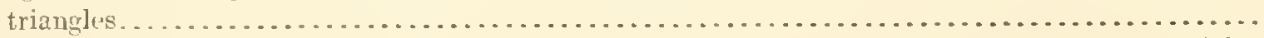

8. Diagram illustrating the use of an alinement cliart for the solution of the tangent condition in right-

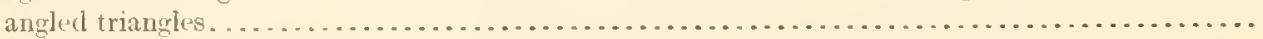

9. Trigonometric computer for the solutiou of such problems as are readily solved with the 12 -inch

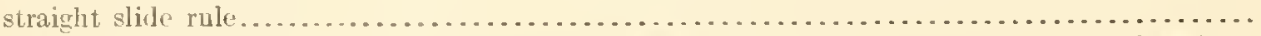

10. Map showing localities where sectious were measured in Washington County. Utah, and Mohave

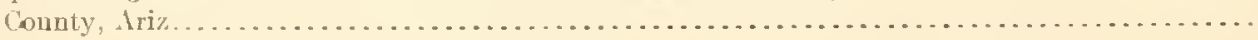

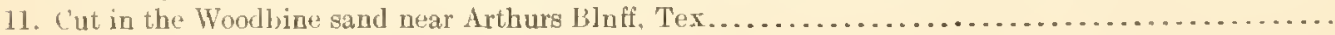

184

185

189 25 


OE924.BA14 14

Berry Edward Wilbe/The flora of the che

111111||||||||||

35185000945517 
